Memoirs of the Mugeum of Comparative zoölogy

AT HARVARD COLLEGE.

Vor. XL. No. S.

\title{
NOTES ON. THE CRAYTISHES
}

IN TIIE

UNITED STATES NATIONAL MUSEUM

AND THE

MUSEUM OF COMPARATIVE ZOÖLOGY

WITH DESCRIPTIONS OF NEIV SPECIES AND SUBSPECIES

TO WHICII IS APPENDED

A CITALOGUE OF THE KNOWN SPEOIES AND SUBSPECIES.

BY

WALTER FAXON.

With Thirteen Plates.

CAMBRIDGE, U. S. A.:

printed for the Museum.

JuLY, 1914. 

Memotrg of the Museum of Comparative Zoölogy AT HARVARD COLLEGE. VoL. XL. No. S.

\title{
NOTES ON THE CRAYFISHES
}

\author{
IN TIIE \\ UNITED STATES NATIONAL MUSEUM \\ AND THE \\ MUSEUM OF COMPARATIVE ZOÖLOGY
}

WITH DESCRIPTIONS OF NEW SPECIES AND SUBSPECIEN

TO WHICI IS APPENDED

A CATALOGUE OF THE KNOWN SPECIES AND SLBSPLCLES.

$13 \mathrm{Y}$

WALTER FAXON.

With Thirteen p'lates.

CAMBRIDGE, U. S. A.:

Drinted for the Museum.

JULY, 1914. 



\section{PREFATORY NOTE.}

The following notes on Crayfishes were made during an examination of all the Crayfishes that have been received at the United States National Museum and the Museum of Comparative Zoölogy since ny last paper on these animals was published in the Proceedings of the United States National Museum, Feb. 7 , 1898, 20, p. 643-694, pl. 62-70. I am deeply indebted to the authorities of the National Museum for sending to me the vast amount of material that has come to Washington sinee my last review of the subject. I am also indebted to $\mathrm{Mr}$. IV. P. Hay of Washington, Prof. S. E. Meek of the Field Museum of Natural History, Chicago, Ill, and Dr. A. E. Ortmann of the Carnegie Museum, Pittsburgh, Pa., for the loan of speeimens. 



\title{
NOTES ON THE CRAYFISHES.
}

\author{
Astacopsis australasiensis (Milne Edwards).
}

A stacus australasicnsis M. EDw., Hist. Nat. Crustacés, 1937, 2, p. 332, pl, 21, f. 1-5.

There are two cotypes of this species in the Museum of Natural History in Paris. One of these, a female, has been kindly loaned to me by Prof. E. L. Bouvier. The rostrum of this specimen is long-triangular, excavated, the acumen provided with an upturned, blunt, apieal denticle and a similar denticle on each side; behind the lateral denticles the margins of the rostrum are obscurely erenate. The post-orbital ridges terminate anteriorly in a blunt tubercle: they are chamnelled throughout their length and are followed by two obsolescent tubereles at a little lower level on the gastric region; the hepatic area also is tuberculated and a few less prominent tubercles are visible on the posterior margin of the cervical groove on each side of the earapace. The areola is broad, narrowing from before backward, punctate. Branchial regions obsoletely squamose. Abdomen rather smooth, with a submarginal row of small tubereles on the pleura of the second somite; pleura rounded. Spine on dorsal face of inner branch of posterior abdominal appendages submarginal. Antemul seale of moderate width, flanked with a sharp dentiele on the outer side at the base. Interior process of the epistome triangular, with convex sides, ending anteriorly in an attenuated angle. Chelipeds nearly symmetrical, meros armed below with spines biserially disposed, upper margin thereof also furnished with a few (three or four) spinules; upper margin of earpus armed with two prominent spines, the distal the larger; outer face furrowed longitudinally, slightly tubereulate along the upper edge of the furrow; inner face of the earpus somewhat tuberculate and armed with one spine in the middle of the distal border. Propodite distinetly earinate on the upper border, less distinctly so on its lower border; the superior erest is cut into five teeth, the lower margin is denticulate; the outer face of the propodite is thickly evered with depressed tubereles. Dactylus furnished with one denticle near the proximal end of the upper border. Length, $63 \mathrm{~mm}$; length of carapace, $30.5 \mathrm{~mm}$.; breadth of earapace, $13 \mathrm{~mm}$; length of areola, $9 \mathrm{~mm}$; breadth of areola at anterior end, $6 \mathrm{~mm}$, at posterior end, 4.5 $\mathrm{mm}$.; length of chela, $20 \mathrm{~mm}$; breadth of chela, $10 \mathrm{~mm}$; length of dactylus, $11.5 \mathrm{~mm}$.

Bay of sydney, Verreaux, No. 944, 1837. 
I doubt if this is the specinen figured by Mihe Edwards: he gives as the length of the body, two inches; the figure, which is said to be life size, is $56 \mathrm{~mm}$. long.

Dr. Cinseppe Nobili ${ }^{1}$ also has examined the same cotype belonging to the Paris Museum and is convineed that it belongs to the same species as a male specinen, 66 mm. long, in the Museum of Natural History of Cienoa, said to have been collected by D'Albertis in 1872 on the little island of Sorong in the Strait of Cialevo, northwestern coast of New Guinea. Perhaps a misplacement of labels has occured in this case; the extraordinary distribution of this species implied by the nominal locality label accompanying the Cienoa specinen, as well as the nature of the islet of sorong, make it probable that the specimen was in reality secured at Sychey, Australia, where D'Albertis collected in 1873.

Astacopsis anstralasiensis may turn out to be nothing but an immature stage of A. spinifera.

\section{Astaconelhrops albertisil Nobili.}

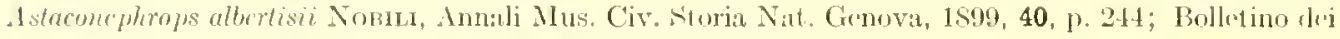
Musei cli Zoologia ed Anatomia Comparata cli Torino, June 9, 1903, 18, p. 1.

The genus Astaconephrops, with its one species albertisii, based on a single female speeimen in the Museum of Genoa which is said to have come from Katau on the southern coast of New Cuinea, needs further elucidation. Aecording to Nobili the margins of the rostrum (which in a general way resembles the rostrum of Paranephrops) are continued back, in the shape of two keek, over the earapace to the cervieal groove: the abdoninal segments are produect into points laterally; the inner branch of the last pair of abdominal appendages is furnished with a rib or keel on the dorsal face, terminating in a spine near the ecntre of the branch; the chelae are long and slender and on account of the clevation of the middle of the two fares appear subprismatical; the earpus is eylindrical, or rather depressed, and amed on the imer side with a sharp spinc concealed in a large tuft of hairs; the inner margin of the pahm is furnished with minute teeth, all the rest of the patm being smooth; the fingers are unarmed, but provided with hairs along their cutting edges.

From the description of this animal given by Nobili one would infer a combination of the characters of Nephrops, Paranephrops and Cheraps. The

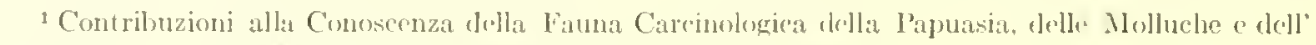

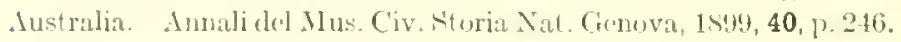


branchial formula is the same as in the genus Cheraps, and essentially the same as in Paranephrops; but aceording to Nobili the podobranchiae of the eighth and ninth somites are not furnished with an ala or lamina in the genus Astaconephrops, whereas in the genus Cheraps these podobranchiae are alate.

\section{Parastacus araucanius, sp. nov.}

Plate 4.

Male:- Cephalothorax shorter than the abdomen, strougly compressed laterally, mostly snooth, minutely granulated on the sides; areola broad (about two thirds as broad as long), minutely punctated; rostrum short, not reaching the distal end of the seeond antennulary segment, margins elevated, slightly convergent from base to near the tip, where they abruptly converge to form the abbreviated acmmen; the infero-lateral edges of the rostrum are risible from above, forming the superior border of the orbit separated from the supero-lateral edge of the rostrum by a groove; distal half of the rostrum concave above; antero-lateral margins of the carapace produced into a prominent, rounded angle below the small eye which lies in a deep and uneommonly complete orbit. Post-orbital ridges, obsolete. The pleural angles of the abdomen are rounded, the telson long with a pair of lateral spines and a longitudinal median furrow on its upper face along its distal half; the median rib on the upper side of the inner branch of the last pair of abdominal appendages ends in a small spine situate a little distance from the margin. Antennal scale short and broad. The chelipeds are asymmetrieal, the right one being the larger; the meros is tubereulated on its lower faee, granulate on the superior margin, but destitute of spines; the surface of the carpus is lightly squamoso-granulate, the granulations becoming more pronomeed on the supero-interior edge where they take the form of blunt tubercles; the chela, too, is lightly squamoso-grauulate, without any prominent spine or tuberele, except one blunt tubercle or tooth near the base of the immorable finger; the superior and inferiol borders are rounded.

Dimensions. Length, $42 \mathrm{~mm}$; length of eephalothorax, $19 \mathrm{~mm}$; length of areola, $6 \mathrm{~mm}$., breadth of areola, $4 \mathrm{~mm}$.; length of larger claw, $15.5 \mathrm{~mm}$., breadth of do., $7 \mathrm{~mm}$., length of dactylus, $8.5 \mathrm{~mm}$.

Corral, Chile, Dec. 18, 1908, in a caseade stream. Thomas Barbour coll., M. C. Z., No. $7,3,55$.

This species is related to P. nicoleti (Phil.) and P.hassleri Fax. Like these it has a strongly compressed cephalothorax, indieating a burrow-clwelling species. 
It differs from both of these species in its short and broad areola. Compared with $P$. nicolcti, it differs in the lack of seulpture of the chela and earpus. Compared with $P$. hassleri, the rostrum is shorter, broader, and more abruptly truneate, the chela is rounded above and below and unprovided with the erest-like series of low, squamous tubereles.

Six species of Parastacus have been previously described from Chile, viz.:P. chilensis (NI. Edw.) in 1837, P. spinifrons (Philippi) in 1852, P. nicoleti (Philippi) in 1882, $P$. bimaculalus (Philippi) in 1894, $P$. agassizii Fax. in 1898, and $P$. hasslcri Fax. in 1898. The type of $P$. chilensis, a single dry specimen, is in the Muscum d'Histoire Naturelle in Paris, and should be more fully deseribed, since Mihne Edwards's diagnosis (Hist. Nat. Crust., 1837, 2, p. 333) is entirely insufficient. In 1849 (Ciay's Hist. Chile, Zool, 3, p. 211, Atlas, 2, C'rust. pl. 1, f. 4) Nicolet described and figured as Astacus chilensis M. Edw. a crayfish certainly different from Milne Edwards's species, and R. L. Philippi therefore gave Nicolet's species a new name, Astacus nicoleti, in a paper published in the Inales de la L'niversidad de Chile, 18\$2, 61. In a paper published in 1898 when I was ignorant of Philippi's paper, I also gave a name to Nieolet's crayfish, fortunately the same name that had been already given it by Philippi. In the same paper Philippi describes and figures a new species, Astacus spimifrons; the diagnosis is as follows:- 1 . rostro elongato-triangulari ad basin utringue spinula acuta; carpo extus profunde suleato, margine superiore grosse tuberculato; mano crassa subtus rotundata; digitis haud lineato-suleatis, intus basi longe barbato-eiliatis.

In 1894 Philippi ${ }^{1}$ published a description of another new species of Parastacus from Chile under the name of Astacus bimaculatus. This is probably the species which I deseribed later by the name of Parastacus agassizii (Proc. U. S. Nat. Mus., 1898, 20, p. 690).

Parastacus spintfrons (Philippi).

Plate 9, Fig. 1.

Astucus spinifrons Panupp1, Anales L'nivers. Clite, 15\$2, 61.

I male Parastacus in the Museum of Natural History, Paris, sent to me for identifieation by Prof. E. L. Bouvier, I think belongs to this species. It differs,

${ }^{1}$ Dos Palabras sobre la Sinnmimia de los Crustáreros, Decépodos, Braquiuros o Jaivas de Chile. Anales Universilitul Chile, 1s94, 87, p. 369-379. I have been unalif to consult either of Plilippi's menoirs diretly. Miss Rathlun, however, has kindly furnished me with a transeript of the earlier one, copied from the rolume of the Anales in the Lithary of Congress, Washington, and Dr. A. E. Ortmann has courteousty lent me a Als. cony of the later paper, given to him hy F. Philippi, son of the author, about 1900 . 
it is true, from Philippi's figures of $P$. spinifrons, at least from the eopy of those figures in Dr. Ortmann's possescion, in some respects, for instance the rostrum is shorter and broader and the inmobile finger of the large elaw is much longer. These discrepancies may he due to the inaccuracy of the original figures or of the copy of these figures which is all that I have before me. Philippi's diagnosis, moreover, takes no aceount of the pronounced asymmetry of the ehelipeds, a marked feature of the specimen from the Paris Museum. I append a description of the latter; future explorations in Chile will determine whether it is the same species as Philippi's.

Cephalothorax subcylindrieal, smooth, shorter than the abdomen; areola broad, eonsiderably less than one half the length of the anterior seetion of the carapace; rostrum triangular, reaching to the distal end of the seeond antennulary segment, upper surface plane, with slightly elevated margins; post-orbital ridges obseurely marked except anteriorly where they form an elongate, low, tuberele without an acute spine; the antero-lateral angle of the carapace is produced to a prominent blunt angle below the orbit: there is no lateral or branehiostegian spine. The abdominal pleura are broad, with rounded angles. The antemal seales are broad, broadest in the middle; lower surface of the pedunele of the antemna hairy; epistoma triangular, anterior angle acute; third pair of maxillipeds elothed with dense hair below. Chelipeds unsymmetrieal, the right one being much the larger, meros pretty smooth, except on its lower' face which is provided with a row of small marginal tubereles and clothed with a heary coat of hair; the superior margin of the meros is destitute of a spine; the earpus has a deep longitudinal groove along its external face; below this groove the surface is smooth, above it there are small squamous tubereles which on the superior border of the earpus assume the form of prominent tubercles, or blunt teeth, four or five in number; the infero-interior face of the carpus of the larger eheliped is likewise furnished with similar tubereles; the right (larger) elaw is very thick, with rounded superior and inferior borders; the body of the claw is beset with flattened low tubereles which are most pronouneed anteriorly, near the socket of the dactylopodite; the fingers gape, are pitted in place of being tubereulated, and there are about three blunt teeth on the eutting edge of each finger, one of which is especially prominent; both fingers are heavily bearded at the base, espeeially on the imner side; the left (smaller) daw is nearly smooth, with long and slender fingers that meet throughout their length, destitute of teeth but furnished with a beard at the base, like the larger elaw. Inner branch of the last pair of abdominal appendages armed with a submarginal spinule at 
the distal end of the median rib. Length, $90 \mathrm{~mm}$., length of earapace, $41 \mathrm{~mm}$, width of carapace, $20 \mathrm{~mm}$., width of base of rostrum, $6.5 \mathrm{~mm}$., length of rostrum, $911 \mathrm{~m}$., length of areola, $11.5 \mathrm{~mm}$, breadth of areola, $7 \mathrm{~mm}$., length of antennal scale, $7 \mathrm{~mm}$., greatest breadth of do., $4 \mathrm{mmn}$, length of larger claw, $31 \mathrm{~mm}$, breadth of do., $17.5 \mathrm{~mm}$., length of superior margin of hand, $10 \mathrm{~mm}$., length of daetylus, $19 \mathrm{~mm}$., length of smaller chela, $23 \mathrm{~mm}$., breadth of do., $9 \mathrm{~mm}$., length of dactylus, $16 \mathrm{~nm}$.

There are four specinens of this species in the U. S. National Museum from the rivulets of MII. Bock and Jones, Lake Nahuel Huapi, on the eastern slope of the Cordilleras in Argentina. The ebelipeds are preserved in three of these specimens; in two the larger claw is on the left side, in one it is the right, as in the Paris specimen.

The tip of the rostrum is setose in this species, and in most eases there are a pair of minute, horny, bead-like lateral teeth just back of the point of the rostrum. The rostrum is therefore essentially like that of $P$. bimaculatus. From the latter the present species differs in having much stouter, shorter-fingered, more heavily tuberculated claws, and a somewhat longer metathorax and narrower areola.

Parastacus agussizii (= bimaculatus) has been reconded from Lake Nahuel Huapi by Ortmann (Proc. Aner. Philos. Aoc, 41, p. 293). The speeimens should be examined anew with reference to the possibility of their belonging to the present species, $P$. spinifrons?

Specimens from Puerto Montt, Lake Llanquihuc, on the opposite slope of the Cordilleras, in Chile, are said by Doflein (Sitzungsher. Akad. Wissensch. München, 1900, 30, p. 133) to agree wholly with my description of P. agassizii (= bimaculatus).

\section{Parastacus binaculatus (Philippi).}

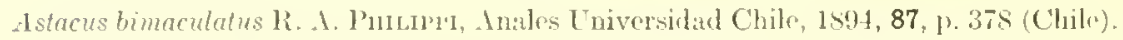

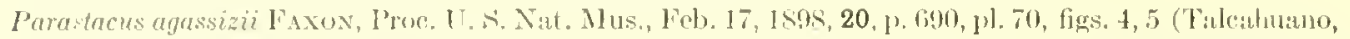
Chile). Dofusin, sitzungshr. Akul. Wissenseh. Münehen, 19)0, 30, p. 132 (Puerto Monit, Lago Llanduihué, Chile). Iswz, Zool. dahrb., Supp., May 2, 1902, 5, p. 736 ('Tumbes, Chilo). Porter, Revista Chishna de Hist. Nat., Dic. 31, 1904, 8, p. 258, Pl. 9 (Contulno and Chillín, Chile).

1 The arror in the branchial formulit of $P$. agassiziz as it appears in my paper in the Proc. U. S. Nat-

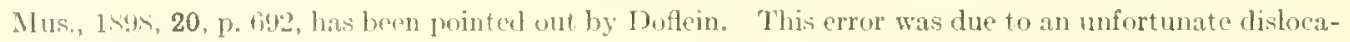
tion of the table in printing, as is evident on comparing the table of the hranchial arrangement in the genus ]aratacus on p. 683 . 
A single speeimen of this species has been lately received at the Museum of Comparative Zoölogy from Valparaiso, Chile.

As noted above, $P$. agassizii has been reeorded from Iake Nahuel Huapi in Argentina by Ortmamn (Proe. Amer. Philos. Soc., 41, p. 293). Śpecimens from this loeality in the U. S. National Museum belong to a different although similar species, P. spinifrons (Phil.)? and Dr. Ortmann's determination should therefore be verified.

I think that my $P$. agassizii is the same speeies as the one previously deseribed by R. A. Philippi in 1894 under the name of Astacus bimaculatus. Philippi's description is as follows:-

"Astacus bimaculatus Ph.

“A. eephalıthorace utrincue macula magna triangulari, albida notato; rostro clongato, peracuto, utrinque ante apicem denticulo armato, unde lineae elevatae sensim divergentes nascuntur; elaelis valde inaequalibus, sinistrit majore; carpo ejus extus jnflato, velut bullato, margine snperiore unispinoso; digitis gracilibus, denticulatis. longit. corporis $72 \mathrm{~mm}$, chelac majoris $37 \mathrm{~mm}$.

"El color del eurpu es oscuro siendo una mezcla de negro veruloso i dle pardo rojizo, como en las denas especies, i en cado lado sir ve una gran mancha triangular blinquizca; su supurficie es lisa, pero las patas anteriores están cubjertas do granulaciones bastantי gruesas, que faltan solo en la parte inflicta del earno. El pico sis casi tan largo como la escama situada en la hase de lis antenas esteriores; se adelgaza paulitinanente on una punta mui aguda e inclinala. De calo lado i mui cerea de la punta se notan dos dientccitos puntiagudos, le dondc parten listones bastanto clevados $\mathrm{i}$ agudos, qui diverjen

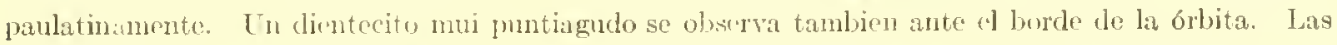
patas anteriores son mui desiguales, da izquierda es mucho mas larga i sobro todo mas gruesa; por lo demas su hechurat es la misma. En el borde superior del artículo terecro se nota una cspina, i los o tres en el borde inferior. Il carpo muestra tambien una o dos espinas en su borde superior, i en su laulo esterior una hinchazon casi suni-globosa, mui notable en el eapo izquierdo, menor pero bien aparente en el derecho. La mano es nuicho mas angosta i estirarla que en las otras fres especies chilenas, sobre todo los declos, euyo horde intorior es finamente dentado. Las otras partes del cucrpo no ofrecen nada de particular."

This description agrees pretty well with the species which I deseribed as $P$ agassizii, but I do not know what Philippi means by asserting that the figure of Astucus fluvintitis in the Régne Animal of Curier (Disciples' Ed., pl. 49, fig. 2) is an exact representation of his new Chilean species. The colour of the specimens from Taleahuano had long since vanished when I deseribed them. Porter, however, has more recently deseribed the living colours of $P^{\prime}$. agassizii, and they seem to conform in the main to the colour scheme of $P$. bimaculatus as described by Philippi :

"El color es en el vlorso i flancos del cuerpo bruno-oliráces, notándose en cada costarlo del cefalotórax, por detras del sureo "«vical, una gran mancha triangular de color amarillw limun enyo vértice

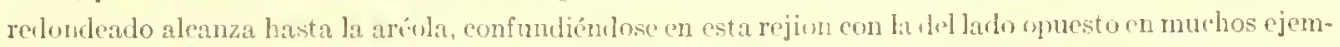
plares. I veces se vé adentus una mancha renlondeada del mismo color a poros unilímetros del borde anterior del carapalo. Los tubereulillos escamifornes de las quelas lo misno que las espinitas del rostro 
son anaranjados, color que se ohserva on la parte inferior del cuepo o inferior e interna de las patas. Estas últimas son de color bruno-oliváceo o bien oliváceo, esperialmente en las quelas."'

With reference to the large triangular colour-pateh on each side of the earapace of $P$. bimaculatus as deseribed by Philippi and of $P$. agassizii as deseribed by Porter, it should be observed that spots of the same shape and in the same place are often seen in erayfishes of divers kinds shortly after they are immersed in aleohol. These spots or blotehes are the result of the quick action of the alcohol on the thinnest part of the branchiostegites, which are bathed in the fluid on both sides, within and without. It first red, these spots afterwards fade into yellowish white,- the colour which ultimately perrades the whole of the body in specimens preserved in spirits. One is almost inelined to suspect that the colour-pat tern noted by Philippi and Porter was due to recent immersion of the speemens in alcohol.

\section{Astacus leniusculus Dana.}

A large number of specimens of this species were eollected for the U. S. National Museum in Johnson Creek, Portland, Multnomah Co., Oregon, by Messrs. Lyon and Benediet in May, 1905. The largest of these are upwards of five and one half inches long and demonstrate the faet that this speeies has as full, obese a forn as A. trowbridgii. There is considerable variation in relative width of the areola in these speeimens. Of twenty-six specimens, eighteen $\left(7 o^{7}, 11\right.$ \%) have the right and left claws symmetrieal, while in eight $\left(5 o^{7}, 3 \%\right)$ the claws are asymmetrical. In many of the asymmetrieal individuals I think the smaller, slenderer elaw, which may be either on the right or left side, is a new claw grown after the loss of the original one.

In a male specimen colleeted by Mr. S. E. Meek, in Ten-Mile Lake, Florence, Lane Co., Oregon, Oet. 17, 1896 (U. S. N. M. No. 23,121), the chelae have the form characteristic of $A$. leniuseulus, and both pairs of post-orbital spines are developed as in that species, but in the shape of the rostrum and the proportions of the areola it agrees with $A$. troubridgii. Inother speeimen in the U.S. National Museum from Astoria, Clatsop Co., Oregon, resembles A. troubridgii in the breadth and inflation of the elaws and the length of the posterior seetion of the earapace. Still another speeinen in the sane Museum (collected by Mr. Wm. Palner) from the base of Nt. 'Tamalpais, Narin Co., Cal., taken altogether would be classed with $A$. trovbridgii; yet in the proportions of the posterior sec-

$$
{ }^{1} \text { Porter, op. cit.. p. 2iss. }
$$


tion of the earapace and the areola it agrees rather with $A$. leniusculus. As these two speeies inhabit the same region it is possible that they interbreed and produce hybrids.

\section{Astacus tronbridgil Stimpson.}

Astacus trowbridgii stands midway between A. leniusculus and A. klamathensis. As it varies in one direetion towards the former speeies, as has just been shown, so, on the other hand it passes through intermediate forms into the latter species. Such intermediate forms I have seen from Wilson Creek, Willapa, Pacific Co, and Littlerock, Thurston Co., Washington; and Sinslow River, Mapleton, Lane Co., and Wallowa Lake, Oregon. In dealing with small, immature individuals it is often difficult if not impossible to decide whether they should be assigned to A. klamathensis or to A. trowbridgii.

\section{Astacus klamathensis Stimpson.}

Plate 11, 12.

Astacus klamathensis has a wide distribution in British Columbia, and in the states of Idaho, Washington, Oregon, and northern California, in the vast area drained by the Columbia River and its tributaries as well as in the smaller streams that empty into the Pacific Ocean on the west side of the Cascade Range of mountains.

New localitics:-Idaho: Indian Creek, Washington Co. Washngton: Goldendale, Klickitat Co.; Granite Lake, Spokane Co.; Naches River, North Yakima, Yakima Co.; Crab Creek, [Douglas Co.?]; Creek near Hemp P. O.; Salmon River; Prairie Creek; North River; Willapa River, Holeomb, Nasel River, Nasel, Pacifie Co. Oregon: Wallowa Lake, Wallowa Co.; Silver Creek, Harney Co.; Bear River, Medford, Jackson Co., Johnson Creek, Portland, Multnomah Co.; Nehalem Rirer, Tillamrok Co. Californa: Shasta River, near Montague, Siskiyou Co.; Cottonwood Creek, near Hornbrook, Siskiyon Co.; Priceland and Garberville, Humboldt Co.

In a lot of two dozen or more specimens of this speeies from Portland, Oregon, in the U. S. National Museum, a slight rariation from the typieal form is apparent in the lengthening of the rostrum and antennal seale and the more pronounced granulation of the chelae. In these regards they show a slight approach towards A. trowbridgii. Many of these individuals have lost their 
claws and grown them anew (see Plate 11, 12). It is interesting to note the restored claws never assume the normal form but are elongated and flattened. When both chelipeds have been lost and re-grown simultaneously, the result is an individual with perfectly symmetrieal claws on the right and left sides, so different in shape from the normal claws that one might easily be led to believe that it is a distinet species. Such a specimen is shown in Plate 12, fig. 2. The restored claws in these cases assume an ancestral, less highly sperialized from.

Astacus Nigrescens fortis, subsp. nov.

Plate 7, Fig. 5, 9; Plate 9, Fig. 2.

Similar to Astaeus nigreseens, from which it is distinguished by the following characters:- the sides of the rostrum converge more from the base to the tip; the areola of the carapace is narrower in proportion to its length; the chelae are shorter, lroader, and more inflated.

Dimensions of a male:- length, $94 \mathrm{~mm}$.; length of carapace, $49 \mathrm{~mm}$; width of carapace, $26 \mathrm{~mm}$; length of abdomen, $45 \mathrm{~mm}$; width of abdomen, $24 \mathrm{~mm}$.; length of posterior section of carapace, $19 \mathrm{~mm}$.; width of areola, $6 \mathrm{~mm}$.; length of chela, $42 \mathrm{~mm}$; wilth of chela, $19 \mathrm{~mm}$.; length of dactylus, $22 \mathrm{~mm}$.

Types:- Fall River, Fall City Mills, Shasta Co., Cal., Aug. 29, 1898, Rutter and Chamberlain coll., U.S. N. M., No. 44,404, $20^{7}, 3$ o , 1 jur.

Paratypes:- Hat Creek, Cassel, Shasta Co., Cal., Aug. 30, 1898, Rutter and Chamberlain coll., U. S. N. M., 3 .

\section{Astacus gambeli connectens, subsp. nov.}

Plate 7, Fig. 6, 10; Plate 10, Fig. 1.

Similat to A. gambelii (Cirard), but different in these regards:- the rostrum is narrower and longer, with a longer acmen, and in correlation with this the antennal seales are much longer, their internal margin sloping gradually to the lengthened apical spine. The post-orbital ridges, though rudimentary, as in A. gambelii, derelop a pair of prominent posterior spines as in A. migreseens, while the anterior pair - the only post-orbital spines found in 1. gambelii - are much more prominent than in that form. The chelae are longer and slenderer than in $A$. gambelii.

Types:- U. A. N. MI. No. 23,096, Snake River at Upper Salmon Falls, Idaho, Oct. 3, 1894, Eremmann and heovill coll., $3 \sigma^{7}, 1$ \%. 
Paratype:- Silvies River, Burns, Harney Co., Oregon, July 27, 1904, J. O. Snyder coll., 1 \% . U.S. N. MI.

This form bears the same relation to A. gambelii as A. leniuseulus does to A. trowbridgii. In the development of the posterior pair of post-orbital spines it shows an affinity to A. migresecns. It appears to be connected with $A$. gambelii by intermediate forms. A large male upwards of $3 \frac{1}{4} \mathrm{in}$. long in the U. S. National Museum, collected at the mouth of St. Joe River, Coeur d'Alene Lake, Idaho, has the long narrow rostrum and the elongated hand and fingers of $A . g$. connectens, but the posterior pair of post-orbital spines are wanting, and specimens (also in the U. S. National Museum) from Warm Springs, Harney Co., Oregon, in most respects like typical $A$. gambelii, show traces of the posterior post-orbital spines.

Dimensions of a male:- Length, $65 \mathrm{~mm}$; length of carapace, $34 \mathrm{~mm}$.; length of abdomen, $31 \mathrm{~mm}$.; length of postcrior scetion of carapace, $11 \mathrm{~mm}$; width of areola, $5 \mathrm{~mm}$; length of chela, $31 \mathrm{~mm}$; breadth of chela, $7.5 \mathrm{~mm}$.; length of dactylus, $18 \mathrm{~mm}$.

Astacus leptodactrius Eschscholtz.

New locality:- Myslowitz, Gemany, 1893, Coll. Hofer, (U. S. N. M., No. 43,317) 1 o

Astacus pallipes italicts, subsp. nor.

Plate 8, Fig. 2.

In the Italian Crayfish as compared with the typical form of A. pallipes from France, the margins of the rostrum are less convergent from the base to the lateral pair of spines, so that the breadth of the rostrum between the lateral spines is greater; the rostral acumen, foo, is longer. The sides of the abdominal segments end in a clistinctly more acute angle. The chelae are more coarsely gramulated, the granulations or small tubercles separated by wider intervals. The anterior proeess of the epistoma is more broadly triangular. The antennal scale is larger, longer, and terminates in a more prominent spine. The tip of the inner part of the gonopods of the male is produced beyond the tip of the extermat part, whereas in A. pallipes the tips of the two parts are subequal. The telson is relatively broader.

Types:- U. S. N. M., No. 25,63S, River Samo, Pompeii, Italy, June 10, 1900, Dana Coolidge coll. 11 ॐ, 9 ㅇ. 
Two speeimens, 1 o , 1 \%, in the U. S. N. M., No. 20,073, from Piobesi, near Turin, Italy, received from the Turin Zoölogieal Museum agree in the essential characters with the Pompeiian specimens.

From these speeimens I infer that the Cisalpine erayfishes constitute a marked geographical race, which in some respects (viz. the form of the rostrum, antennal seale, epistoma, and gonopods) shows an approach to Astacus astacus. It is not, however, liable to be confounded with that speeies, sinee the median earina of the rostrum is not denticulated, and the post-orbital ridges are entire, not broken up into an anterior and a posterior seetion as is the ease with Astacus astacus. In the important matter of the branchial apparatus, moreover, Astacus pallipcs italicus differs from $A$. astacus and agrees with $A$. pallipcs in having but two rudimentary pleurobranchiae on each side of the body, upon the eleventh and twelfth hody-segments. ${ }^{1}$

The crayfish found in the neighbourhood of Madrid. Spain, is in almost every respect like the typieal French Astacus pallipes. It does, however, show an approach to the Italian examples in one regard, viz. an cnlargenent of the anterior process of the epistoma, and with this in a few speeimens goes a tendency toward a broadening of the rostrum. It would nevertheless be an over-refinement to separate the Spanish erayfishes from Astacus pallipes.

\section{Cambarus digueti Bouvier.}

Cambarus diguti Bouv., Bull. Mus, d'llist. Nat., Paris, 1597, 3, p. 225.

Cambarus carinatus Faxon, l'roc. U. S. Nat. Mus., Fol, 17, 1898, 20, p. 648.

New locality:- Oeotlan, State of Jaliseo, Mexico (Field Mus. Nat. Hist.).

\section{Cambarus pilosimanus Ortmamn?}

A young female erayfish, $35 \mathrm{~mm}$. long (M. C. Z., No. 7,405) was collected by Mr. J. L. Peters at Camp Menzel, 36 miles from the mouth of the IIondo River, in the Territory of Quintana Roo, Mexico, Mareh 27, 1912. It is elosely affined to C. pilosimames and $C$. williamsoni of Ortmann, if not identical with one of these. It presents certain features, howerer, that are not found in either of Ortmann's species; viz: - there are two well-marked spines, one above the

1 This was detcrmined by examination of the branchial apparatus of two examples from the type lot of A. p. itulicus from the River sarno. The rudimentary gilis horne on the weventh and welf h somites liav. the form of relued simple filaments representing the stem of the completely formed gill. 
other, on each side of the latero-anterior margin of the earapace, above the welldeveloped branchiostegian spines. This is a feature that one would not str.peet to be a jurenile mark, and it may denote specific diverwity. There are, moreorer, two sharp spines on the second segment of the antennae near the base of the antemnal scales.

The ehelae of the specimen collected by Mr. Peters are stender and neirly smooth, the fingers sparsely pilose, the spines of the carpus and nerus well dereloped, as in young specimens of $C$. pilosimanus according to Ortmann. The anterior segment of the telson is three-spined on each side, the inner spine being rery small; the median longitudinal rib on the dorsal face of the inner branch of the last abdominal appendages ends in a spine some distance from the posterior margin.

The type locality of $C$. pilosimanus is Coban, Guatemata. Dr. Ortmann also records one specimen, in the Museum of Nitural History of Paris, from Belize, British Honduras, a locality not very remote from the place where $\mathrm{Mr}$. Peters got his specimen. Mr. A. S. Pearse (13th Ann. Rep. Mich. Acad. Ści., 1911, p. 110) has more recently recorded it from C'uatotolapan, Canton of Acayuean, State of Vera Cruz, Mexico. The type locality of C. williamsoni is Los Amates, Province of Izabal, Cuatemala.

\section{Cambarus mexicanus Erichsom.}

New localities:- Mexico: Tuxtla Gutierrez, state of Chiapas (U. A. N. M., No. 30,580); Jalapa, State of Vera Cruz (Fiełd Mus. Nat. Hist.).

Mr. 1. S. Pearse' has recently redescribed this species unler the name cambarus mutheni, sp. nov. from the hacienda of Cuatotolapan, canton of Acayuean, State of Vera (1ruz, Mexico, altitude, 15 metres.

\section{Cambarus cumensis Erichonn.}

New localitics:- C'uba: Nmendares River, Calabazar', Province of llabana (U. S. N. M., No. 31,881); Unión de Reyes, Province of Matanzas ( II. ( ' . Z.. No. 7,633); Ciego de Avila, Province of Camagiey (Coll. J. T. Nichols).

There is a small specimen, a mate, onl $y^{\frac{3}{4}} \mathrm{in}$. long, in the U. .. National MIuseum (No. 28,625), from Nueva Gerona, Isla de Pinos. It was collected hy

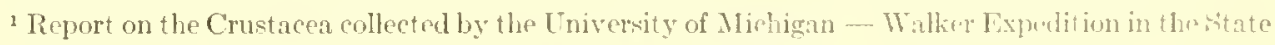
of Vera Cruz, Mexico. Thirteenth Ann. Rep. Nlich. Acat. Sci., 1911, p. 110. 
Messrs. Palmer and Riley, July S, 1900. It may be an immature specimen of one of the races of $C$. cubchsis, or possibly a nearty allied species.

Since the above paragraph was witten, and the specimen returned to the United States National Musemm, Dr. A. E. Ortmann ${ }^{1}$ has described as a new species, Cambarus (Proeambarus) atlinsoni, a crayfish collected by Dr. A. Atkinson in the tributaries of Rio de los Indios, Los Indios, Iste of Pines, May 25, 1910. It is closely related to C. cubensis, from which it differs principally in the much less dilated imner face of the copulatory organs of the male.

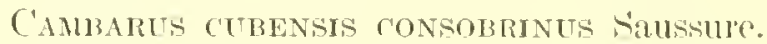

Cambarus consobrimus Satss., Rov, ot Mag. Zool, 1857, sér. 2, 9, p. 101; Mém. Soe, Phygr, Hist. Nat. Genève, 1858, 14, p. 157, 11. 3, fig. 21.

Comburus cubersis consobrime Naxon, 13ull. Mus Comp. Znöl., Oet. I912, 54, p. 458.

In this form of the Cuban Crayfish the rostrun is narower than in the typical $C$. cubensis, more deeply concave above, its margins more distinctly raised and less ronvergent between the base and the pair of lateral spines near the distal end; these lateral rostral spines, moreover, are much better developed than in the typinal form, and the rostral acumen is longer; the post-orbital rider is more prominent, distinctly grooved along its outer face, and produced anteriorly into an acute spine much more strongly emphasized than in the typieal C. cubensis; there is, too, an evident lateral spine on each side of the carapace, on the himel border of the cervical groove,- a spine which is not present in C. cubensis cubensis. The external sexual organs are alike in the two forms.

Nine specimens of this crayfish (5 $0^{7}, 4$ o ), M. ( . Z.. No. 7,343, were secured by Dr. Thomas Barbour from lads who were using them for fish-bait. at sian Antonio de los Baños, in the interior of the Province of IIabana, cuba, April, 1909 .

Cotypes of Saussure's Cambarus consobrimus are now dispersed among the Museums of Cieneva, Paris, Berlin, and Washington, It is very likely that Saussure's material inchuded some of the typieal for m of $C$. cubensis; his description and figures, nevertheless, were grounded on the form with long rostral arenmen, and distinct rostral and lateral thoracic spines; the type locality of consobrinus, moreover, ats speeified by saussure, is the centrul port of the island.

In the rotype in the U. . . National Museum (No. 20,6st, ex Mus. Creneta),

${ }^{1}$ A New Speries of the Genus Cambarns from the Lste of l'ines. Ann Carnegie Mlus, May 5, 1913. 8, 1, $41 \pm+1 \%$. 
a male, dried and transfixed with a pin, the rostrum is abuormal, the right margin thereof being pared away toward the tip, carying with it the right marginal spine. This deformity was evidently present in the living specinen. On the left side the marginal rostral tooth or spine is well developed, as are also the spines at the anterior end of the post-ocular ridges. The lateral thoracic spines too are fairly well marked.

\section{Cambarus cubensis rivalis Faxom.}

Cambarus cubensis rivalis Fax., Bull. Mus. Comp. Zoul, Oet., 1912, 54, p. 459.

Differs from typical C. cubensis (which lives in the low country, near the sealevel) in having a much shorter and broader areola, a shorter, broader, and more heavily granulated claw; the sides of the rostrum, furthermore, are more nearly parallel and they bear a pair of distinct lateral spines at the base of the acumen. In so far as the rostrum is concerned this subspecies resembles C.c. consobrinus, yet it differs from consobrimus by having a short and wide areola and by the absence of lateral thoracic spines. The sexual parts are like those of C. cubensis.

Length of an ovigerous female, $44 \mathrm{~mm}$., length of carapace, $21 \mathrm{~mm}$., length of areola, $6 \mathrm{~mm}$., breadth of areola, $2 \mathrm{~mm}$.

This form is an inhabitant of the mountain streams of western Cuba. The extent of its distribution remains to be determined by further exploration of the island. The type specimens (M. C. Z. No. 7,406), two males of the second form and three females, were caught by 1)r. Thomas Barbour in a mountsin stream near San Diego de los Baños, in the Province of Pinar del Rio, Fel., 1912. There are also specimens in the $U$. A. National Museum from the same place (Nus. $28,626,28,627)$ and also from a mountain brook north of the town of linar del Rio (Nos. 23,656, 23,657).

\section{Cambarts smulans Faxon.}

New loculities:- Texas: Sourlake, Hardin (0. (U. S. N. M.). Irkansas: Saline R., Benton, Saline Co. (T. S. N. M.). OkLshous: MInunt śrott, Comanche Co. (U. S. N. M.).

Under the name Cambarus gallimus this species has been recorded by Messis. T. D. A. Cockerell and Wimath Porter (Proc. Acad. Nat. Nei. Phila., 1900, p. 434-435) from the Gallinas liver at Las Vegas, San Miguel (\%, in lakes at Watrous, Mora Co., and from Roswell, Chares Co., in the State of Now Mexico. 
Its range is now known to include the five states, Texas, Arkansas, New Mexico, Oklahoma, and Tiansas.

\section{Cambarus gracilis Bundy.}

New localities:-Ihunous: Abingdon, Knox Co. (U.S. N. M.); O(quawka, Henderson Co. (U.S. N. M.).

\section{Cambarus hagenianus Faxon.}

Plate 1; Plate 7, Fìg. 1, Ћ.

Cambarus carolinus HAsiex, nee Erichson.

Cambarus hagerianus Faxon, I'roc. Amer. Acad., 1854, 20, p. 14.

This species has been hitherto known only through the type specimen in the Museum of Comparative Zoölogy (No. 232), a male of the first form received early in the history of the Museum from Professor Lewis R. Gibbes of Charleston, S. C. The United States National Museum has recently received it in ample numbers from the Agricultural College, Oktibbeha Co., Miss., and also from Muldon, Monroe Co., Miss., and Farmdale, Ala. It is a pest to the cotton growers of these regions, riddling the fields with its burrows, and devouring the young plants; to a less degree it is destructive to young blades of maize or Indian $\operatorname{cosn}^{1}$

Hagnn's Crayfish attains to a length of three inches. It is nearly related to $C^{*}$. gracitis Bundy, replacing that species in more southern loealities. In C. gracilis the sides of the rostrum are more nearly parallel; the sub-orbital angle, which is pronounced in C.gracilis, is wanting in C. hageniamus. The branchiocardiac lines, although contiguous in both $C$. gracitis and $C$. hageniamus for a considerable distance, olliterating the areola, are united for less distance in the former than in the latter; the abdomen is much broader in C. gracilis, and the longitudinal rib on the upper side of the inner branch of the last pair of abdominal appendages terminates in a spine which lies some distance from the posterior margin, while in C. hagenianus this rib extends elear to the margin, where the spine projects freely. The gonopods of the first form male are formed after a similar fashion in $C$. hageniamus, $C$. gracilis, and $C$. simulans; there are three terminal teeth (one of which is compressed or laminate) in $C$. gracitis and $C$.

1 Swe L. A. Depart. Agrir., Rept. Bureau Biol. Surv. for 1911, p. 9; and A. K. Fisher, Crawfish a, Crop I hestroyers, Yearbook U. S. Depart. Agric for I911, 1912, p. 319-324, p]. 22. 
simulans, but the smallest of the three is smaller in $C^{\prime}$. simulans than in $C$. gracilis and lacks the horny texture; in C. hagenianus the truncate end of the gonopods bears but two teeth.

In the second form of the male the gonopods are less perfeetly finished at the tips, the terminal teeth being blunter and membranous. The annulus ventralis of the female $C$. hageniamus is much like the annulus of $C$. graeilis, being produced on each side of the median line into a prominent tubercle, each tubercle tending to denticulation.

The specimens from Muldon, Miss, are peculiar in having a beard along the internal border of the upper face of the hand in the nuales, as in Cambarus barbatus and Astacus gambelii.

Colour of living speeimens from Muldon, Miss.:- Male (Plate 1, fig. 2), metacarapace violet-gray with round greenish spots on the hranehial regions; procarapace greenish, dashed with red anteriorly; abdomen light orange, with two longitudinal rows of irregular olive spots; chelae and earpus olive, the tubereles and granules green; fingers and antennae orange, beard whitish. Female (Plate 1, fig. 1), metacarapace bluish; procarapace, abdomen, and chelae tending to green at the expense of the orange tints.

Few cases of colour differences correlated with sex have been noted among Crustacea. See Andrews, Zool. Anz., Apr. 25, 1911, 37, p. 401.

Cambarus versutus Hagen.

New locality:- Auburn, Lee Co., Alabama (M. C. Z.).

Cambarus blandingit (Harlan).

New localities:-Virainia: Cape Henry, Prineess Ame Co. (U. .. N. M.). North Carolina: Mattamuskeet Lake, Hyde Co. (U. S. N. M.); Reedy Fork, Cape Fear River, Greensboro, Ciuilford Co. South Carolina: Charleston Co. (U. S. N. M.).

\section{Cambarus blandingil acutus (Cirard).}

New localities:- Ilunois: Greathouse Creek, Wabash Co. (U. S. N. M.). Arkansas: Bruce Lake, Little Roek, Pulaski Co. (U. S. N. M.). Maryland: Fulton Co. (U. S. N. M.). Mississippi: Rosedale, Bolivar Co. (U. .. N. M.). Louisiana: Frierson, De Soto Co. (U. S. N. M.). Texas: Angelina River (U. S. N. M.). 
A large male, form I., in the U. 6. National Musemm, collected in $1897 \mathrm{in}$ the Mississippi River at New Orleans, La., measures $5 \frac{3}{8} \mathrm{in.}$ from the tip of the mostrum to the end of the telson, the chelipeds are $6 \frac{7}{8} \mathrm{in}$. long, the ehelae $3 \frac{3}{4} \mathrm{in}$. long. The dimensions of a male of about the same size were given on page 23 of my Revision of the Astacidac. This specimen also eame from New Orteans (M. C. Z.. No. 3,327) and is the same one whose measure was giren by Dr. Hagen on page 37 of his Monograpl of the North Ameriean Astacidae with an errour of orer an inch in the length.

\section{('ambarts hayt Faxoll.}

New loculity:- Agrieultural College, Oktibbeha Co., Nississippi (U. s. N. M.).

\section{Cambarus fallax Hagen.}

Neu loculitirs:- Fuorids: Auburndale, Polk Co.; Kissimmee River. between L. Hatch and Kissimmec, Osceola Co.; Lake Monroc, near Sanford, Orange Co. St. Johns R., at Palatka, Putnan Co.; St. Johns River at Beecher Point.

\section{Cambatids acherontis Lömberg.}

New locality:- Eustis, Lake Co., Florida, 2 f. II., 7 o , in U. S. N. M.

\section{Cambartes clarkit Girard.}

New Loculities:- Texas: Fort Clark, Kimney Co.; Seguin, Cuadalupe Co.; Sin Narcos, Hays Co.; Houston, Harris Co.; Corpus Christi, Nueces Co.; Angelina River; Bcaumont, Jefferson Co. Loussans: Lake Lepourde, Morgan City, Saint Mary Co.; Melville, Sinit Landry Co.; Frierson, De Soto Co. Arkansas: Little Rock, Pulaski Co., (1 o coll. by O. P. IIay, U. S. N. M., No. 19,762). Sll of the above are in the U. . . National Museum.

Is noted in my Revision of the Astacidac, p. 26, specimens of C. clarkiz from New Orleans, La., differ slightly from the typical specimens from western Texas in having the branchio-cardiac lines in close apposition for a long distance through the procarapace, obliterating the areola and reducing the size of the anterior and postcrior triangular fields. 'This is well shown in Roetter's beautiful drawing of a specimen from New Orleans in Hagen's Monograph of the North Anerican Astacilae, Pl. 4. 


\section{CaMbarts rlarkit paENINSUlants, Suhep. nov.}

The examples of Clark's crayfish found in the peninsular portion of the State of Florida differ slightly, albeit eonstantly, from the typical Texas form in being smoother, in having a more tapering rostrum, and a slorter and broader antemul scale; there is moreover a slight difference in the shape of the tip of the male sexual appendages: the anterior terminal tooth being narower and more acute than in the typical form in which this tooth is broaler, more laminate and less acute at the tip; in the Floridan subspecies, too, the anterior half of the telson bears on each side from three to five spines, while in the typical C. clarkii there are but two spines on each side.

Type: M. C. Z., No. 3,530, 1 o $^{\text {T }}$ f. II. Three miles below Horse Landing, st. John's River, Florida, Feb. 9, 1869, J. A. Allen.

There are a good many specimens of this subspecies in the U. S. National Mnseum collected by W. C. Kendall at Beecher's Point, st. John's River, Fla., in Fehruary and March, 1897, Nos. 28,587, 28,589.

\section{Cambirus wegalanni Erichison.}

This species is still imperfectly known; Erichson's type, which came from Mexico, is no longer extant; it was described as having hookis on both the third and fourth pairs of legs in the male. I female individual from Mexico, in the collection of the Acudemy of Natural seiences of l'hiladelphia, was referred to this species by Dr. Hagen and myself, although with wome doubt on aceount of the want of male specimens. In 1906 Dr. Ortmann (Proc. Washington Acad. Sci., 8, p. 15-19) described and assigued to this species a male belonging to the Philadelphia Academy, collected by Professor E. D. Cope in 1855 in Lake Xochimileo, south of the City of Mexico, in the Federal District; in this specimen the legs of the third pair are furnished with a rery small tuberele only, while those of the fourth pair are armed with a strongly developed hook.

Four specimens, three nuale, one female, recently collected by $\mathrm{N1}$. W. M. Mann at San Mignel, State of Hidalgo, Mexico, and now in the Museum of Comparative Zoölogy, conform to Ortmann's description of the Cope specimens, barring the fact that there is no vestige of even a tuberele on the third pair of legs of the male, the fourth pair alone being provided with hooks; these specimens may represent an undescribed species, but on account of the sad dearth of requisite material and the loss of the type of C. wiegmami the clucidation of this question must needs be deferred to a later time. 
CAMBARUS VAAE-viRidis, sp. nov.

Plate 5.

Male, form I: - Rostrum long, triangular, plane above, margins raised so as to form a sharp rim, destitute of lateral spines or angles; acumen strongly deflexed, not clearly defined; a shallow depression or foreola at the posterior cnd of the rostrum. Carapace punctate above, finely gramulate on the sides; post-orbital ridges telminating bluntly before; eervical groove sinuate, interrupted on each side; no lateral spine, branchiostegian spine minute; areola narrow, equal in length to about one half the distance from the cerrical groove to the tip of the rostrum. Abdomen punctate, pleural angles rounded off, hind border of auterior section of the telson bispinose on each side. Anterior process of the epistome triangular, with slightly eonvex sides. Intemal seale short and very hroad, truneate at the anterior end. Chelipeds of moderate length; upper margin of the meros serrated, below there are two series of spines; carpus tuberculate and spinulose on the inner face; chela of moderate proportions, with slender fingers; superior margin of the hand spinulose, outer and inner faces spinuloso-tuberenlate; daetylus spinulose through the proximal quarter of the superior horder. Basal segment of last pair of thoracic appendages provided with a crest. which is produced on the inner side into a projecting tooth. Third segment of third and fourth pairs of legs hooked. First pair of abdominal appendages rather short, tip truncate, outer part furnished with a prominent horny tooth and two minor denticles, inner part terminating in a straight spine, the end of which does not reach to end of the largest tooth of the outer part.

Length $45 \mathrm{~mm}$., carapare $23 \mathrm{~mm}$, areola $7.5 \mathrm{~mm}$., width of areola $5 \mathrm{~mm}$. length of hand $17.5 \mathrm{~mm}$. I ength of palm $S \mathrm{~mm}$., width of palm $5.5 \mathrm{~mm}$. Iength of fingers $9.5 \mathrm{~mm}$.

Annulus ventralis of the female transversely broad, with a deep sigmoid sulens which is open in front.

St. Franeis River, Greenway, Clay Co., Arkansas, Aug. 1894, S. E. Meek coll. M. C. Z., No. 7,336, 10 specimens, or and o.

This species is allied to Camburus exermanni Fax. from Pensacola, Fla. It differs in having the upper surface of the rostrum flatter, with depressed acumen, the areola narower, the hand broader, and also by the different eharacter of the tips of the male appendages. It falls into the group of species represented ly C. chemanni Fax., C. barbatus Fax., C. wiegmanni Eriehs., C. hinei Ortm., and $C$. alleni Fax. 


\section{Cambarus alleni Faxon.}

New localities:-F Lorida: Fort Florida, Volusia Co. (M. C. Z.); ponds near Tampa, Hillsboro Co. (U. S. N. M.); Iake Butler, Tarpon Springs, Hillsboro Co. (U. S. N. M.); Lake Iohopekalize, Kissimmee, Osceola Co. (U. S. N. M.).

\section{Cambarus shufeldti Faxon.}

There is a male of this species, $21 \mathrm{~mm}$. long, in the U. S. National Museum, collected by Robert Fennicott at Cairo, Ill. It has been previously known only from the original type lot collected near New Orleans, La., by Dr. R. W. Shufeldt in 1883 .

\section{Cambarus montezumae Saussure.}

New locality:- Acambaro, State of Guanahuato, Nexico (Field Mus. Nat. Hist.).

Cambarus montezumae dugesil Faxoln.

New localities:- Mexico: Chalco, State of Mexico; Celaya, State of Guanahuato; Lake Quitzeo, Huingo, State of Michoacan; La Barca and Lagos, State of Jalisco; all of these are in the Field Museum of Natural History; they were collected by Prof. S. E. Meek in 1901.

\section{Cambarus montezumae chapalanus Faxon.}

New localitics:- Patzcuaro and Zirahuen, State of Michoacan, Mexico (Field Mus. Nat. Hist.).

\section{Cambarus montezuma occidentalis Faxon.}

Two males, collected by Prof. S. E. Meek, in Lake Quitzeo, Huingo, State of Michoacan, Mexico, and now deposited in the Field Museum of Natural History, appear to belong to this subspecies. It has been already recorded from the same place by Dr. A. E. Ortmann (Proc. Washington Acad. Sci., 1906, 8, p. 20). 


\section{Cambartis slodin Bundy.}

Four sucemens, males of the second form, collected by Mr. W. P. Hay between Paoli and Wrandotte, Ind. (U. S. N. M., No. 19,776), and determined by Mr. Hay as ( ${ }^{*}$ sloanii, differ in sone inportant regards from the types of C. sloanii from New Albany, Ind.: The tip of the inner ramus of the gonopods is not deflected inward so strongly, the rostrum is longer, with a longer acumen, the large claws are distinctly narrower, with relatively longer fingers, and the outcr row of spines on the lower face of the nerus of the cheliped is reduced to a single terminal spine. These specinens perhaps represent a new species or subspecies, but in the absence of the first form of the male and the female I refrain from naning it.

\section{Cambarus affinis (Nay).}

Nou loculitics:- Manuland: Sam's (reek, Frederick Co. (U. S. N. M.); Little Pipe Creek at U'mon Bridge and near New Windsor, Caroll Co. (U.S. N. M.); Northwest Branch near Hyattsville, Prince Georges Co. (U. A. N. M.). THRgnia: Orkney springs, shenandoah Co. (U. S. N. M.). MAssarhusetts: Bancroft's Pond, Brown's Pond and Spring Pond, Peabody, Essex Co. (M. C. Z.); Mansfield Pond, Great Barrington, Berkshire Co. (M. C. Z.);

This species, whose real home is in the rivers that flow into the Itlantic in New Jersey, Pennylrania, Maryland and Tirginia, is now well established in the town of Peabody, Essex Co., Mass. How or when it got there I do not know. The first report of it came to me in $190 \mathrm{I}$ when the late J. H. Sears lnought me a specinen $90 \mathrm{~mm}$. Lomg, which he had canght in Bancroft's Pond, Peabody, on the the of August of that year. In tept., 1911, Dr. Joln C. Phillips secured a good nnany (43) specimens from spring Pond, Brown's Pond and Bancroft's Pond in Peaboly, some of them attaining a length of 95 mm. Dr. Phil-

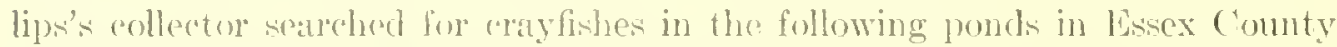
with negative rosults:- IIood's, Stephens, l'our-Mile, Nites's, Fipofford's and Perley Pond in Boxford, and Chebaces, Beck's, Round and Gravelly Ponds in Hamilton.

On the 1tth of June, 1912, I captured a female C. affinis, with young under her abdomen, in Mansfield Pond, (ireat Barrington, Berkine C'o., Mass.

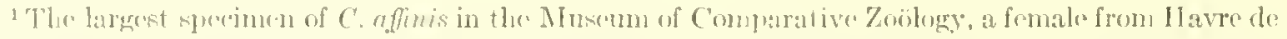

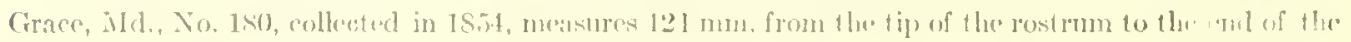

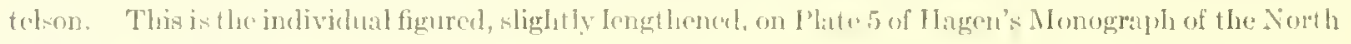
American Astacilae. 
I was told in Great Barrington that these animals were introduced $10-15$ years ago into Lake Buel, on the borders of the neighboring towns of Monterey and New Marborough, by anglers who were using them as fish-bait, that they are now exceedingly numerous in Lake Buel and have been probably transferred thence to neighboring ponds by boys.

C. affinis has been introduced into Europe as a piscicultural experiment in aeclimatization at the Station Agricole at F'eamp, Franee, ${ }^{1}$ and elsewhere.

This speeies has also been found of late in C'entral Park Lake, New York City, and in Prospect Park Lake, Brooklyn; it has also been reported as introduced into a lake in East Hampton, Middlesex Co., Conn. (Bull. N. Y. Zoöl. Soc., Nov. 1912, 16, p. 924).

\section{Cambarus propinguus Girard.}

New localities:- New York: Mumnsville, Madison Co.; Gilennmark Creek, North Rose, Wayne Co.; Chammont River, Batavia, Cienesce Co.; Seneea Lake; Mud Creek and Saint Lawrence River, Cape Tineent, Jefferson Co.; Griffin's Creek, Chammont, Jefferson Co.; Stony Island, Jefferson Co.; Stony Creek, Henderson Harbor, Jefferson Co.; Sandy Creek, North Hamlin, Monroc Co.; Nime-Mile Point, Webster, Monroe Co.; Selkirk, Oswego Co.; Marsh Creek, Point Breeze, Orleans Co.; Tonawanda Creek; Canada Way Creek, Dunkirk, Chautauqua Co.; Van Buren Point, Chantauqua Co.; Silver Creek, Chautauqua Co.; Cattarangus Creek. OHo: Cowles Creek, Genera, Ashtabula Co.; Conneaut Creek, Kingsville, Ashtabula Co.; Rocky River, Olmsted Falls, Cuyahoga Co.; Port Clinton, Ottawa Co.; Catawba Island, Ottawa Co.; Lakeside, Ottawa Co. Indina: Tippecanoe Rirer, Deloug, Fulton Co.; Sims, Crant Co.; Winona Lake, Kosciusko Co.; Eagle Lake, Warwaw, Koseiusko Co.; Evansville, Vanderburg Co.; Eel River and Blue River, Columbia City, Whitley Co. IlunNois: Wabash R., Hutsonville, Crawford Co. (Mus. Comp. Zoöl.); Kankakee River, Momence, Kankakee Co.; Illinois River, Havana, Mason Co. Mrchigan: Raisin River, Monroe, Monroe Co.; Black Creek, Iexington, Sunilac Co.; Port Sanilac, Sanilac Co.; Grand River below Lansing, Ingham Co.; Wolf Lake, Jackson Co.; Long Lake, S miles north of Alpena, Apena Co.; Tawas City, Ioseo Co.; Au Sable River, Au Sable, Ioseo Co.; mouth of Carp River, 12 miles from Straits of Mackinae; Mullet Lake, Cheboygan Co. (U. S. N. M.). Mexico: Jimenez, State of Chihuahua (Field Mus. Nat. Hist.).

The loeality Jimenez, Mexico, is such an extraordinary one for this species ${ }^{1}$ Acclimatation des Eurevisses Amélicaines. Revue Scientifique, Jan. 9, 1S97, ser. 4, 7, p. 56. 
that one might well suspect some error if the origin of the specimens were not so well attested. Seven specimens, males of the first form, now in the Field Museum of Natural History, were collected by Mr. S. E. Meek, together with four female C. virilis, June 9, 1901, in the drainage of the Rio de los Conchos, one of the southern tributaries of the Rio Grande. They were picked out from among the fishes which were the chief olject of Mr. Meek's exploration of Mexico and sent to me for determination in January, 1902.

The conditions obtaining at the time and place of their capture are thus described by Mr. Meek in his account of the fishes secured during his Mexican explorations of $1901:^{1}$

"At. Jimenez the Rio Conehos was nearly dry. Our collections were mate from a few deep holes about two niles below the eity. These contained a large amount of aquatic vegetation, which made rollecting diflieult and unsatisfactory. The water was very dear, and in the deeper places were seen nany large suckers which we were unabh to eapture. Sunfishes were very albundant. All of these streams become large and deep in the rainy season, at which time the Rio Conchos at Jinninez beeomes two hundred or more feet in wilth and as much as fifteen feet in depth."

\section{Cambarus propinguUs saniornil Faxon.}

New Inculities:- Ono: Black Rirer, Elyria, Lorain Co.; Hudson, Summit Co.; Vermilion Rirer; Cuyahoga River, Kent, Portage Co.; Dorer C'reek, Dover, C'uyaloga Co. West Virginia: Horse Creek (U.s. N. M.).

\section{Cambarus obscurus Hagen.}

New localities:- New York: Cattaraugus Creck. West Virginia: Cassity, Randolph Co.; Cheat River, Ises Ferry, Fand Run, Childer's Run, and Trubie's Rum, near Buckhannon, Upshur Co.; Queens, Upshur Co.; Weston, Lewis Co.; Hitcker's Creek, near Janelew, Lewis Co.; Ten-Mile Creek at Lumberport, Harrison Co.; Deeker's Creek above Morgantown, Monongalia ('o. (U. S. N. M.).

('amburus obscurus is an abundant river species in the Upper Ohio River Basin in northern West Virginia, and western Pennyshania. It is also found in the Lake Erie and Iake Ontario drainage in the states of Pennsylvania and western New York, and in Wills Creek, an affluent of the Potomae River, at Hyndman, Bedford Co., Pa., and Ellerslie, Mllegany Co., MId. ${ }^{2}$ In the U.s.

'A Contribution to the Iehthyology of Mexieo. Fiehl Cohnmbian Museum, Publ. 65, Zool. Ser., May, $1902,3, \mathrm{p} .65$

2 ()rtmann, Nem. Cimegie Nus, 1906, 2, p. 4.15. 
National Museum there is a female erayfish (No. 22,518) colleeted by D. S. Jordan in northern Wisconsin which looks like this species, hut the locality is an extraordinary one for this species and should not he acepted as authentic until confirmed by securing more material.

\section{Cambarus rusticus Cirard.}

New localitics:- Iowa: West Fork of Des Moines River, Spring Tale, Humboldt Co. (M. C. Z.). Oню: Sandusky River, Fremont, Sandusky Co.; Presque Isle, Perrysburg, Wood Co. Indina: Moot's C'reek, White Co.; Salmonie River, Mount Etna, Huntington Co. KentuckY: Salt River. Tennessen: Richland Creek, Nashrille, Davidson ('o. (U.S. N. M.).

\section{Canbarus neglectus Faxon.}

New localitics:-- Missouri: Indian ('reck, MeDomald ('o. (U. .. N. M.). Colorado: Republican River, Wray, Iuma Co. (M. C.. \%.).

Cambarus spinosus gulielmi, subsp. nov.

Cambarus spinosus IIAY, Proc. U.S. Nit, MIus, 1902, 25, p. 439 (nee Isundy).

Cephalothorax shorter than the abdomen, densely punctate above, granulate on the sides, the granules largest on the hepatie region where they assume the form of small tubercles; the whole surface, but more particularly the sides, is elothed with fine sctae arising as pencils from the pits of the dorsal surfaee and the granules of the sides; the rostrum is deeply exeavated above, its sides parallel from the base to the lateral pair of teetl at the base of the moderately long, triangular apex; the post-orhital ridges are prominent and provided with a small tooth at the anterior end; the sub-orbital angle is obliterated, but there is a well-developed branchiostegian spine, as well as a lateral spine on the cerrical groove; the section of the carapace behind the cervical groove in the median dorsal line is a little less than one half the distance from the eervical groove to the tip of the rostrum. Areola of moderate width. The anterior segment. of the telson bears two spines on each side. The anterion process of the epistone is moderately broad, its sides convex, its anterior angle rounded off. The antennal flagella are long and slender, - longer than the body; the seale or seaphocerite is of moderate width, widest at a point a little anterior to the middle. The chelae, like the earapace, bear numerous setac springing from the pits and 
tubereles on its surface; the inner border of the hand is furnished with squamoid tubereles disposed for the most in two longitudinal rows; along the distal half of the outer border of the hand there runs a low, but well-marked, earina; the (lactylus is tubereulate on it. free border, blunt-toothed (like the immobile finger) slong its prehensite edge and ridged longitudinally along its outer faee; the (arpus is armed with an aente spine on the middle of its internal border, and with a small tuberde at each end of the same horder; helow, the median earpal spine is woll prononneed and there is a small acute spine at the inferior point of artienlation with the propodus; the fwo eustomary spines are present near the anterior end of the upper margin of the merus; the outer of the two pows of spines on the lower face of the merus is reduced to two at the distal end. The dorsal carina of the inner branch of the last abdominal appendages terminates in a tooth a lit the distance within the hind margin.

The gonopods, in the second form of the male, are long and straight, reaching forward, when the abdomen is flexed, as far as the basal segments of the second pair of legs; their rami are rather thick, blunt at the tip, and the outer one is hut a trifle longer than the inner one; when viewed from the inner side the two rami are fused up to within a short distance of the end of the organ.

The anmulus ventralis of the female is bitubereulate in front, unitubereulate behind, the anterior and posterior walls being separated by a transverse fossa which is divided longitudinally by the sigmoid fissure.

Dimensions of a fenale:- length, $73 \mathrm{~mm}$., length of carapace, $37 \mathrm{~mm}$, length of rostrum from tip to a level with the post-orbital spines, $11 \mathrm{~mm}$., width of rost rum at base, $5 \mathrm{~mm}$., length of areola, $12 \mathrm{~mm}$., width of areola, $2 \mathrm{~mm}$., length of cheliped, 54.5 mm., length of chela, $27.5 \mathrm{~mm}$., breadth of chela, $12 \mathrm{~mm}$., length of dactylus, $16 \mathrm{~mm}$.

This crayfish is closely related to the Cambarus sprinosus of Bundy, but is different in the following respects:- the body is more villous, the metararapace longer in proportion to the procarapare, the anterior process of the epistome is much narrower than in the types of Bumdy's species and (what has most weight in regarding it as a subspecies) the external sexual organs are elearly different. The gonopods in C.s.gulielmi being shorter, the rami thicker, blunter, nearly equal in length, and separate for but a short distance from the tip, while in C. spinosus the rumi are slemler, pointed, the outer one exceeding the immer by a great distance and the split between the fwo parts involving a large part of the length of the organ. The ammulus rentralis of the female, though of the same type as that of the typical C. sprimosus, differs slightly in having a more open transverse fossa. 
The villosity may be an evanescent character, as it is a condition often apparent in individuals that have recently undergone a moult; at a later period the setae are apt to disappear by attrition.

U. S. National MIuscum, Nos. 20,379, 12 o t. II., 14 ㅇ. From a small stream flowing from a pond fod by the cave stream known as . Iohn Ross ipring, near Rossville, Walker Co., Gourgia, Aug. 23, 1901, William Perry Hay coll.

\section{Cambarus petwami faxon.}

Upward of one hundred specimens of a erayfish closcly resembling C. putnami were collected hy Mr. W. P. Hay in southwestern West Tirginia in the summer of 1900 . They were found in the shallowel parts of streams, wsually under flat stones, - in Barrenshe Creek, near Perryille, U. S. N. M., No. 25,018, 28,613, and Iorsepen Creek, (L. S. N. M. No. 28,612) and War Creek (U. S. N. M. No. 28,614). In these specimens the rami of the gonurods are a trifle longer than in the types of ('. mutnami from Kentiekr, the rostrum, moreover, shows a pretty constant faint carina on its upper surface, near the tip, and the anterior angle of the epintome is truncate. These peculiarities do not seem to me important enough to separato this form nominally from C. putnumi.

Aceording to Mr. Iny's notes their colour when alive was olive-green on the dorsal surface of the body and chelipeds, changing to vinaceous on the sides, under parts and other appendages; the tips of the fingers were horn-yellow and preeeded by a rather broat hand of dark orange-red.

\section{C'Anisares longidigitus Faxom.}

New loculity: - James River, springfield, (ireen Co., Missouri (U. N. N. MI. No. 20,856).

James River, Missouri, without further sperifiration of locality, is the type locality of Cambarus whitmoni hitede, which as far as "an be seen from the deseription is the sane as ('. Imaghligitus.

\section{C'ambarts virils Hagen.}

Neu localities:- Ixdind: Prairie Creek, Scotland, Green C'o. Ilbixols: Henderson Co.; Kankaker River, Momenee, Rankakee (o. Mnurax: Belle Isle, Detroit, Wayne Co.; Pigeon Piver, Casprille, Huron ('o.; Bind Creek, Port

${ }^{1}$ Unir. Cincimnti Bull. No, 10, 1902, 1. 24. 
Austin, Huron Co.; Sand Beach, Huron Co.; Pimnebog River, Port Crescent, Huron Co.; Mud Creek, Bay Port, Huron Co.; Black River, near Port Huron, Saint Clair Co.; Pine River, West Harrisville, Aleona Co.; Au Sable River, Au sable, Ioseo Co.; Rabbit's Back Creek, 5 miles above Saint Ignace, Mackinac Co.; 12 miles from Straits of Mackinac. MrNnesota: Deer River, Itasea Co.; Lake of the Woods. Nortir Dakota: Borit's Ford, Cheyenne River. Nerraska: Lineoln Creck, York, York Co. Mrssouri: Clinton, Henry Co. (U. S. N. M.). Colorado: Republican River, Wray, Yuma Co. (M. C. Z.). Mexico: Jimenez, State of Chihuahua (Field Mus. Nat. Hist.).

The Mexiean specimens (four females) were eollected by Mr. S. E. Meek from deep holes, Rio de los Conchos, about two miles below Jimenez, June 9, 1901. For the circumstances of their capture, see under Cumbarus propinquns, page 373,374 .

\section{Cambarus muunis Hagen.}

Plate 2, 6.

New loealities:- Nebraska: Norfolk, Madison Co. (U. S. N. M.); Elkhorn River, Fremont, Dodge Co. (U. S. N. M.); Omaha, Douglas Co. (MI. C. Z.). Missourt: Lake City, Jackson Co. (M. C. Z.). Iowa: West Fork of Des Moines River, Spring Vale, Humboldt Co. (MI. C. Z.). Mrcmigan: Pine River near West Harrisville, Alcona Co. (U. S. N. M.); Caseville, Huron Co. (U. S. N. M.); mouth of Bunce River, south of Port Huron, St. Clair Co. (U. S. N. M.). Ilunom: Wabash Co. (U. S. N. M.); Indian Creek, Abingdon, Innox Co. (U. S. N. M.); Illinois River, Havana, Mason Co. (U. S. N. M.). Onro: Cedar Point, and Presque Isle, Toledo, Lucas Co. (U.S. N. M.); Toussaint River, ten miles below Port Clinton, Ottawa Co. (U. S. N. M.). New York: Pond near the mouth of Cattaraugus Creek, Chautauqua Co. (U.S. N. M.); silver Creek, Chautauqua Co. (U.S. N. M.); Fish Creek, Buffalo, Erie Co. (U.S. N. M.); Stony Island, Jefferson Co. (U. S. N. M.). Massachusetts: Pontoosue Lake, Lanesborough, Berkshire Co. (M. C. Z.); Onota Lake, Goodrich Pond and Housatonic River, Pittsfield, Berkshire Co. (M. C.Z.); East Washacum Pond, Sterling, Worrester Co. (M. C. Z.); Blackstone River, Uxbridge, Worcester Co. (M. C. Z.); Lake Boone, Stow, Middlesex Co. (Boston Soc. Nat. Hist.); Walden Pond, Concord, Middlesex Co. (M. C. Z.). New Hampshme: Lake Wimepesaukee (U. S. N. M.).

Cambarus immunis, taken as a whole, has an enormous range, as a common species, through the western states, from northem Ohio, through Indiana, 
Illinois, Michigan, Wisconsin, Minnesota, Iowa, Missouri, Kansas and Nebraska, into Colorado and Wyoming. " To the eastward of Lorain County, Ohio, it has hitherto been recorded fiom only two localities, both in the state of New Fork: in $1891 \mathrm{Mr}$. Cierrit smith Miller, Jr., brought me three speeimens which he found in July of that year in a small stream flowing into Oneida Lake; these were recorded by me in 1898 (Proe. U. S. Nat. Nus., 20, p. 654); in 1906 Dr. Ortmann (Mem. Carnegie MIus., 2, p. 467) ealled attention to sperimens in the New York State Museum which lad been taken by Mr. F. C. Paulmier in Rensselaer Lake, Rensselaer Co., N. Y. I ean now add to the New York stations for this species the following:- pond near the mouth of Cattaraugus Creek, and silver C'reek, Chautauqua Co. (U. S. N. M. Nos. 22,417, 22,408); Fish Creek, Buffalo, Erie Co. (U. S. N. MI. No. 22,418); and Stony Island, at the eastern end of Lake Ontario, Jefferson Co. (U. S. N. M. No. 22,409).

My first knowiedge of this species as an inhabitant of Massachusetts was obtained when I was walking across the mud-flats at the upper end of Pontoosuc Lake on the 11th of Norember", 1899. The numerous mud-towers or "chimneys" here rising above the level of the flat at once betrayed the abode of some kind of burowing crayfish. Although the soil was then frozen so as to make exploration difficult, I satisfied myself that the builders of the little mudtowers had withdrawn to their brumal retreats in the deeper waters of the Lake, leaving behind them only one dead companion, a first-form male C. immunis spinirostris (M. C. Z. No. 6,687). Here the matter rested until, during a risit to Berkshire in 1911, I ascertained that this crayfish was abundant on the I2th of August among the water-weeds at the head of Pontoosuc Lake. Two days later I searehed for it at the northem end of Onota Lake in Pittsfield and again found it in altogether similar surroundings, albeit in much smaller numhers than in the neighbouring Pontousuc or Lanesborough Pond.

On the 15th of June, 1912, I again collected this crayfish at the outlet of Goodrich's Pond and in the Housatonic River just above Pomeroy's Mills, in Pittsfield.

These specimens from Berkshire Co., Mass, agree in most respects with the types of $C$. immunis spinirostris, which were collected in Obion County, Temnessee. The rostrum in the Massachusetts examples tapers a little more between the base and the ante-apieal tecth and, the antemal scales are a little shorter in proportion to the length of the rostrum. Compared with the typical

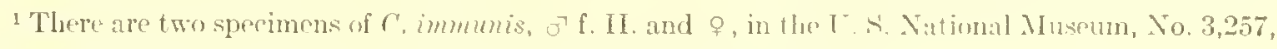
labelled as coming from (rizalu, Mrexien, through Professor Sumichrist. 
form of $C$. immunis from Illinois, $C$. immunis spinirostris differs in laving a distinct spine or tooth on each side of the rostrum near the tip, more prominent post-orbital and branchiostegian spines and a shorter posterior section of the carapace in relation to the section in front of the cervical groove (the proportion being $1: 2$ or even less in C. i. spinirostris); the claw, too is narrower, with proportionally longer and slenderer fingers.

In full-grown living speeimens from Pontoosuc Lake (Plate 2, fig. 2) the dominant colour of the carapace is a rich Vandyke brown shading into tawny olive on the sides; the cardiac area is conspicuonsly marked off by being a murh lighter colour,- tawny olive; the abdomen is beautifully mottled above with darker. and lighter shades of tawny olive; the legs are olive-coloured.

In the young, $27 \mathrm{~mm}$. long, from the same locality (Plate 2, fig. 1), the brown of the adut is replaced by an olive-green which pervades the whole chorsal side of the ereature and is delicately varied by mottling of olive-buff; the cardiac area is of the latter hue and is continued backward, through the whole length of the abdomen, as a broad median band; the appendages are delicate olive-grcen, changing to a pinkish tint at the tips of the claws.

C. i. spinirostris was first described from Obion County, Temnessee; it hats also been recorded from Omaha, Nehraska (Pearse), Shawnee County, Lansas (Faxon), Douglas County, Kansas (Harris), Vigo County, Indiana (IT. P. ILay), Ottawa Co., Ohio (Pearse), and Long Point Creek, Canada (Pearse). As a matter of fact, specimens of $\mathrm{C}$. immunis agreeing more or less closely with the form which I described as var. spinirostris are to be found pretty much thronghout the range of the species. I have seen such among material collected in Nobraska, Kansas, Missonri, Michigan, Illinois, Indiana, Ohio, and New York. I an therefore disposed to regard it as a variety rather than a true geographical race or subspecies, although it is true that all of the Massachusetts specinens possess the characters of spinirostris.

When Cambarus immunis was first diseovered in Berlsshire County, Miss., it had been recorded from only one place (Oneida Lake, X. Y.) rast of Lorain County, Ohio, and in the State of Ohio it had been recorded from but three localities - Huron River at Huron, Erie Comnty (Osburn and Williamson, fith Inn. Rept. Ohio State Icad., 18!98, p. 11), Sandusky, Eric County (Faxon, Proe. U. . . Nat. Mus., 1898, 20, p. 654), and Lake Erie, Lorain Co. (Osbum and Willianson, l. c.). I was therefore formerly inclined to think that its presence in Berkshire County, Mass., was due to artificial introduction, like the Cambarus affuis in the ponds of Esicex County, Mass.; but I have now before me specimens fron 
along the Ohio shore of Lake Erie from Lueas County, through Ottawa County, to Erie and Lorain Counties, from the New York horders of the sane Lake in Chautanqua and Erie Counties, from the eastem end of Lake Ontario and from Lake Oneida: while Ortmann's diseovery of the specimens in the Albany Museum from Renssalaer County, $\mathbf{N}$. Y., extend the eastward distribution of this crayfish up to Berkshire County, Mass. In the light of all the evidence now eollected it seems to me possible, if not probable, that Berkshire County is the eastern limit of the natural distribution of this species and that the discontinnity results from imperfect exploration of the waters of New York State. It should be noted however, for what it is worth, that the Berkshire countrymen whom I have questioned believe the crayfishes are a comparatively late addition to the fauna of the Lakes.

However this may be, there ean be no reasonable doubt that the presenre of this crayfish in Woreester and Middlesex Counties, Mass., and in Lake Timnepesankee, $\mathrm{N}$. H., is the result of artifieial transference at a comparatively recent date. The first time this animal was found in Walden Pond, Coneord, Middlesex County, Mass., so far as I can learn, was in the summer of 1909, when two or more were captured, as I am told by MIr. Reginald Heher Howe, Jr., of the Middlesex School, Concord. In $1910 \mathrm{Mr}$. Howe sent me a fine specimen, a make about $3 \frac{3}{8}$ inches long, which had been taken in the Pond, and in early October, 1911, the Rev. Smith Owen Dexter and Nr. H. Richardson of Coneort seeured two specinens by a long search under the stones on the edge of Italden. Mr. Dexter's specimen, taken from the Pond the 9th of October, when about $1 \frac{1}{2}$ inches long, lived in my aquarium until April 6, 1912, ensting its shell twice, on February 20 and March 19, and attaining a length of $1 \frac{3}{4}$ inches. On the 14 th of June, 1912, Mr. Dextel collected four specimens, ranging from $2 \frac{1}{2}$ to $4 \frac{1}{2}$ inches in length, from the borders of the Pond, and still more luxing the following month. On the 24th of July, 1912, Mr. IT. F. Clapp and I got six speeimens there.

I have been told by citizens of Concord that two men who fished in TIalden Pond about ten years ago (c. 1903), using crayfishes for bait, threw their surplus bait into the Pond and thus unwittingly stocked it with these reartures.

Vralden Pond is apparently a most unrongenial abule for Cumburus immunis. being clear as a well and almost lestitute of regetalle growth. 'The faromite haunts of this speeies are rather mudly waters stockel with a rank growth of pond weeds.

In 1913 specimens of this erayfish were eollected in Bonno Pond, Stow, 
Middlesex County, Mass., by Professor G. H. Barton. Boone Pond drains into the Assabet River. Walden Pond has no visible inlet or outlet.

Dr. D. L. Belding, of the Mass. Fish Commission, collected several specimens in East Washacum Pond, Sterling, Worcester Co., Mass. (Nashua River drainage), Oct. 10, 1912; Mr. W. F. ('lapp found many in the Blackstone River, at Uxbridge, Worcester County, Mass., Sept. 29, 1913, and there is a specimen in the United States National Museum collected in 1913 in Lake Winnepesaukee, N. H.

In colour as well as in all other characters the Walden Pond and Blackstone River specimens agree perfectly with those from Berkshire Connty. Those from Boone Pond, Sterling, and Lake Wimnepesauke I have seen only after they had been immersed in alcohol and lost their colour; in other respects they too are conformable to the Berkshire County variety, i. e., C. i. spinirostris.

\section{Cambarus ralides, sp., not.}

Plate 7, Fig. 3, 4, s; Plate 13, Fig. 1

Male, form I. - Similar to C. immunis Hag., but differs as follows:- the rostrum is relatively narrower, less tapering from the base to the lateral angles at the proxinal end of the acumen, its margins are more distinetly raised so that the upper surface of the rostrum appears to be more deeply hollowed out. The foreola at the base of the rostrum in C. immunis is searcely evident in C. ratidus. The chela is very much larger, more powerful and of a different form from that of C. immunis; the immovable finger is curved strongly outward at the base, giving a convex outline to the external margin of the hand; the movable finger is furnished with a double row of tubercles ruming along its external marerin, while the inner margin is not excised at the base and is armed with a row of eight or nine round bead-like tubereles; the chela is as long as the carapare, and broad and inflated. The lower face of the carpus is furnished with only a ludimentary, blunt, median spine or tuberele. The sub-orbital angle is less prominent, the posterior wall of the orbit forming a perpendicular straight line. The anterior process of the epistome is much broader, with the anterior end truncated but not notched. In other regards, including the form of the sexual appendages it agrees with C $\mathrm{C}$.mmunis. The rostrum is deroid of lateral teeth or spines. like the typical form of $($. immunis.

Length, fo mm.; length of carapaec, $33.5 \mathrm{~mm}$. ; length fomm tip of rostrum 
to cervical groove, $22 \mathrm{~mm}$; length of chela, $35 \mathrm{~mm}$; breadth of chela, $15 \mathrm{~mm}$.; length of dactylus, $21.5 \mathrm{~mm}$.

Huntsville, Madion C'o., Mabinua. One male, form I. M. C. Z., No. 301.

This specmen was considered to be ('. immunis by Hagen, is mentioned by him on page 72 of his Monograph, and its chela is probably the one figured by him on Pl. VIII, fig. b. Compare my "Revision of the Lstacidae," p. 100.

six specinens in the U.s. National Museum, three of which are males of the second form, and three females (No. 23,092) eollected by Mr. J. E. Benedict at Nashville, Temessee, in May, 1897, without much doubt are conspecifie with the type specimen of $C$. validus. Is they are younger than the type specimen, and as the first form of the male is not represented among them, the peeuliarities of the species are not so well pronounced. The ehelae are proportionally smaller and the curve of the immobile finger is less. This finger, as in the type specimen and in C. immunis, is heavily bearded within at the base. The gonopods of the males are similar to those of second-form males of $C$. immunis, but less strongly curved; indeed the eurve of the stem of the organ is no greater than it is in $C$. viritis, but the blunt recurved tips are subequal as in $C$. immunis; in other words the shape of the second form male organ is the same as in C.alabamensis. The anmulus ventralis of the female is virtually the same as in $C$. immunis.

\section{Cambanus mississippiensis Faxon.}

New locality:- Agrieultural College, Oktibbeha Co., Mississippi (U. S. N. M.).

\section{Cambarus lanctaer Hagen.}

A female specimen, collected by Robert Kemnieott at Cairo, Ill., is in the U.s. National Museum. The few speeimens heretofore known have eome from Root Pond, Miss., Vieksburg, Miss., and the St. Francis River at Greenway and Big Bay, Clay Co., Ark.

\section{Cambares bartoni (Fabricills).}

New localities:- Mane: Little Madawoska River, a tributary of Iroostook River at New Sweden, Iroostook Co. (M. C. Z.); brook tributary to Aroostook River at Caribou, Jroostook Co. (Coll. W. P. Hay). New Tork: Schoharie Creek, Catskill Mts., Green Co. alt. 2,000 ft. (U. S. N. M.); Little 


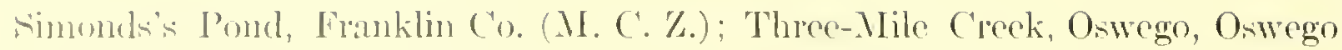
(i) (l. A. N. M.). limgina: Broad Rum and Gap Run, Fauquier Co. (UT. N. N. M.); Orkney Springs, Shenandoah Co. (U. S. N. M.); Stony Man Mt.,

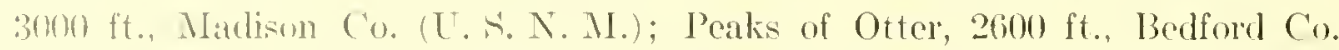

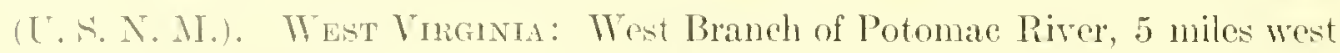
wil (irederille, Pondloton Co. (U. S. N. M.); Rich Creek, Spanishburg, Mercer Co. (L. A. N. M.); 'Trubie's Run, 7 miles above Buckhannon, Upshur Co. (T.... N. M.). North Calolina: Looking-Glass Creek, Transylrania Co., 3:300 ft. ( (T. S. N. M.); near Nontreat, Buncombe Co. (U. S. N. M.). TEnNHASEE: 7 miles northwest of ('hattanooga, Hamilon Co. (U. S. N. M.); little Rirer, al trilutary of the 'Temessee River at Cate's Cave (U. S. N. MI.).

The Jautum's (rayfish of Aronstook County in Northem Maine (of which thene is a large collection in the United states National Muscum from the Allogish River a littre ledow (hamberlain Lake, Churehill Lake, Eagle or

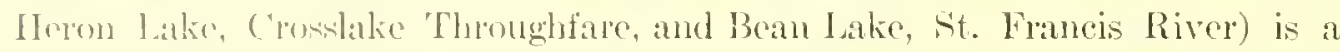
small, elean form that in these clear, cool, northern waters shows a slight difforentiation from the typieal C'. bartomii from the Middle states. The lostrum is more stromgly decurved and the fingers are narower and more eylindrival and gape widely at the hate. The differenees between this form and the type nerentheless do not seem to be great enough or constant enough to warrant a subsuceific separation.

Cambares bartont calinirostris Hay MS., subsp. nov.

"Rostrum of nedium length, very broad, nearly plane or slightly excarated albere and with a more or less distinct, modian, longitudinal carina; acumen short, hroad, with concave sides, its tip strongly upturned. Carapace with a spinulowe angle hetow the eye; branchiostegian spine obsolesent; areola of moderate width. Tedson bi- or tri-spinose on each side. Antennae, when extended hackward, reaching heyond the middle of the abdomen. Chelipeds stout and heary, chelac broad and strong, heavily punctate above and below; imer margin of hind obseurely serrato-denticulate; fingers usually gaping at the base, stromg down eurved, pitted in lines, upper surface heavily ribbed. Otherwioce essentially the same as typical C. bartonii.

"This form, which 1 regard as a well-marked subspecies, is in typieal examples very liko ('. burtomii in general, lunt different in the following regards:the catrapare is a little none cylindrieat, the rostrum broader and flatter, and 
always furmished ncar the tip with a median longitulinal carina. This carina is usually well defined and extends from near the acumen backward to about the middle of the broad flat surface of the rostrum; it is generally followed by an illdefined and very shallow foveola. In less typical specimens the earina is reduced to a rery low, rounded, almost invisible elevation just between the lateral angles of the rostrum, or in some cases is wanting altogether; in such specimens the other characters, - eylindrical carapice and broad, flat rostrum, - will hardly be sufficient to separate them from other elosely related subsperies.

"Type, U. S. Nat. Mus. No. 23,962. Candy Creek, Osceola, Randolph Co., W. Va. W. P. Hay coll., July 12, 1899. Mas, forma secunda.

"This crayfish is abundant in the main strean as well as in the tributaries of the Tygart's Valley and Cheat Rivers in Randolph Commty, West Virginia. I have collected typical examples from the Tygart's Valley River at Beverly and near Elkins. It is most abundant, however, further east in the Cheat River basin, and Osceola nay be regarded as approximately the centre of its distribution."- IT. P. Hay MIs.

C. b. carinirostris Hay is a slightly differentiated local form of $C$. bartonii found chiefly in the nountain streans of Randolph C'o., W. Va., the Cheat and Tygart's Valley Rivers and their tributaries. Outside of Randolph County, Mr. Hay secured a few specimens at Mbright, Preston Co., at Quechs, U1shur Co., in the above-naned river-basins. It is also probably to be found in the upper waters of the Kanawha River basin further to the south, since there are a few specimens in the U. A. National Museum (Nos. 23,975, 28,605) from the ITest Fork of the Grecnbricr River, near Dubin, Pocahontas Co., and from Laurel Creek, in second Water Care, near Greenvilte, Nomroc Co., that are pretty characteristic examples of this race.

The median carina on the upper surface of the rostrum in a rather clusive character, in many individuals it is scarcely if at all apparent. Such specimens retain, nevertheless the peculiar quadrangular outline of the rostrum, which is often a trifte broader at the base of the acumen than it is in the middle. The areola is of moderate width and not so thickly pitted as it is in C. b. montanus.

The dimensions of Mr. Hay's type are as follows:-

Length, $63 \mathrm{~mm}$; length of carapace, $32 \mathrm{~mm}$.; length of areolix, $11 \frac{1}{2} \mathrm{~mm}$.; width of areola, $2 \frac{1}{2} 1 \mathrm{~mm}$; width of rostrum between the eyes, $4 \mathrm{~mm}$.; length of chela, $25 \mathrm{~mm}$.; breadth of chela $11 \frac{1}{2} \mathrm{~mm}$.; length of dactylus, $16 \frac{1}{2} \mathrm{~mm}$. 
('AMBARUS BALTONII MONTANUS (Girald).

In looking over any extensive collection of Cambarus bartomii from the Nleghany Mountain region of Virginia and West Virginia one is struck by the tendency of the material before him to fall into two sets of forms, one eharacterized by a lather narrow areola, sparsely sown with impressed points or dots which incline to a serial arrangement in three or four longitudinal rows: while in the other set the areola is shopter and proportionally broader, and its field is thickly strewn with innumerable dots. On further examination it will be seen that the narrower areola usually goes with a shorter and broader bostrum, a more depressed and oval carapace and a narower antennal seate. These two forms are often found in the same locality and with these alone in riew one might be justified in deening them two well-differentiated speeies, but it soon becomes elear that in other places specimens are found that combine in a most perplexing fashion the features of our two supposed species.

The seeond of the two forms above notieed, the one with the shorter and broader and more thiekly punctate areola and longer bostrum is the one too eurtly diagnosed by Girard under the name of Cambarus montanus.

Girard's deseription of C. montanus is as follows:- "Antenne more chongated and more filiform than in C. Bartonix. Rostrum intermediate in sbape between the latter and C. carolimus, heing proportionally longer than in C. Barfomii and shorter and less tapering than in C.carolinus. Dorsal sutures of the carapare more apart than in both of the latter species.

"Localities. - Within the Mleghany ranges in Virginia and Maryland: tributaries of James River in Roekbridge Co. (Va.); Shenandoah River in Clarke Co. (Ta.), and Cumbertand (MLl.) of the hydrographieal basin of the Potomae; Sulphur Spring, Greenbrier River, an affuent of the Kenhawa River (Va.) [now W. Va.] of the Ohio basin."

When Dr. Hagen was preparing his Nonograph of the North Ameriean Astacidae in 1868, he had the opmortunity to examine one of Cirard's types of C. montanus from Greenbrier River, W. Va., sent to him by Wm. Ntimpson who then had the types from the smithsonian Institute in Chicago, where in IS7 I they were most unfortunately destroyed by the disastrous conflagration of that year.

Sixteen yoars later, while I was revising the Astacidie, I had the advantage of elose personal intercourse with Dr. Hagen and free use of his notes and memoranda. The identity of Cinard's Camborus montrmus is thus assured by an unbroken tradition. Neither Dr. Hagen nor myself in my earlier publications seteemed this form worthy of even a subspecifie name, although its characters 
were pointed out in my Rerision, p. 64. It may be well in our present more advanced knowledge of the $C$. bartonii group to recognize C. montunus as a geographical lace or subspecies of C. bartomii.

In the collection of the Academy of Natural seienecs of Philadelphia there is a young male, labelled "Janes River, Va., C. montunus?" which is very probably a cotype or paratype of Cirard's Cambarus montumus. IVith regard to this and other quasi types of Cirard's species in the Philadelphin Academy, the reader' is referred to Hagen's Monograph, p. 7, and my Rerision, p. I1.

I have examined specimens of C. bartonii montamus, nearly or quite typical, from the following localities:- Tringinia: Wy therille, Wythe Co. (U. S. N. M., No. 13,966, M. C. Z., No. 3,S3S); Rocky Gap, Bland Co. (U. S. N. M., No. 23,568.) West Yrirginla: Horsepen Creek, [Mingo Co.?] (U. .'. N. MI. No. 28,5.5.5); Madam Creek, tributary of New River, opposite Hinton, simmers Co. (U. S. N. M., No. 28,556, M. C. Z., No. 7,398); Bergen's Aprings, 12 miles above Hinton (U. S.'. N. M., No. 28,566); Delashmeet Creek, Kegley, Mereer Co. (U. S. N. M., No. 28,610); Bluestone River, just above its mouth, Mereer (o. (U. S. N. MI., No. 28,570); mouth of Delashneet (reek, Bluestone River, Mereer (\%o. (U. S. N. M., No. 28,565); Bluestone River, Abb's Valley (U. K. N. M., No. 28,569); East River, Mereer Co. (U.s. N. M.); Rich Creek, Spanishburg, Mereer Co. (U. S. N. M.); Barrenche Creek, Perrystille, MIcDowell Co. (U. S. N. M., No. 28,573); War Creek, McDowell Co. (U. S. N. M., Nos. 28,564, 28,580); Guyandotte River, Baileysville, Wyoming Co. (U. S. N. M., Nos. 28,562, 28,578, 29 8 ).

Isolated localities from which I have secn specimens of C. bartomii very closely resembling the form montamus in the breadth and punctation of the areola are: Ahm Creek, Franklin Co., Ohio, R. C. Osburn and E. B. Tilliamson (U. S. N. M., No. 22,351), Cincimnati, Ohio (MI. (. Z., No. 288), creek at Tinoxville, Tenn., Walter Faxon (M. C. Z.. No. 3,477). From Cogar's Mill, Elk River, Fanawha Co., W. Va., I have seen an interesting lot of specimens that combine the characters of $(r . b$. montenus and $r . b$. longulus, the rostrum and chela of montanus going with the reduced sub-orbital angle of longulus. These specimens are in the U. S. National Musem, No. 23,990, and in the NInseum of Comparative Zoölogy, No. 7,401.

\section{Cambarus bartonil robustus (Girard).}

Plate 3.

From Cambarus bartomii montamus the passage is easy to C. b. robustus, in which form the rostrum is longer and more tapering, the areolit rather longer and narrower and the outer nargin of the hand more costate, an emphatic de- 
pression ruming along the upper and lower faces of the immobile finger. In the United states National Museum there are many speeimens from West Fork

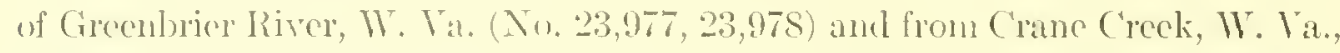
which are very nearly typical examples of C.b. robustus. They differ slightly, it is true, from more northem specinens in having a little broader arcola and less pronounced impressions upon the immobile finger. In these regards they show an approach to ( . b. monkuns, from which the form robustus is probably derived.

specinens collected at Wytherille, Wythe Co., Va. (U. . . N. M., No. 13,966, M. C. Z., No. 3,838) which were refered to (. b. robustus by me in 1890 (Proc. U. A. Nat. Mus., 12, 622) are in reality C. b. montumus.

Examples from Frederiekshurg, Spotsylyania Co., Val, were formerly referred 10 C. robustus hy Hagen in his Monograph, p. So, and by myself in my Revision, p. 61, 67, but they are not typieal extmples of C. robustus. These specimens (AI. C. Z., Nos. 3,615,3,797) are in many wass like to C. acuminalus in the rostrun which is longer and more tapering than in robustus, in the relatively short posterior section of the carapace, greater width of the areola, and the highly developed spines at the hase of the antemal seakes, on the curpus, and on the merns. The lateral spine of the carapace is distinctly developed on alnost all of the liredericksumg specinens. I similan form is found at Raleigh, N. C. (T. . . N. M. No. 22,355).

Ifter eliminting the sperimens which have been wongly identilied with C. robustus, the distribution of the latter race, in its true form, is restricted, as far as known, to the following regions: - Ontabro: 'Toronto, Weston. Menu-

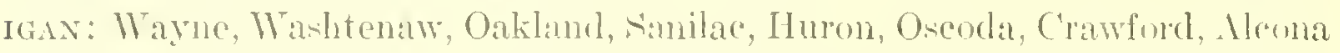
and Ionia Counties. Ono: Knox, Lorain. Cuyahogat, and L hatabula Counties. New Yons: Chautuncula, (Benesece, Mlegany, Momroe, Wayne, Tomphins,

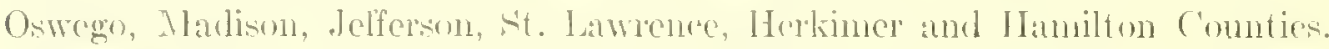

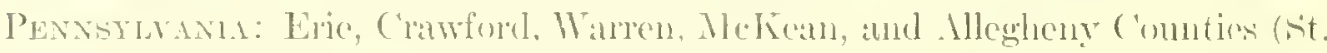

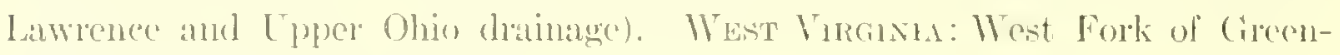
brier River and ('rane Creek.

Cambarus bartomii robustus is a sombre-colourol clayfish in life (Plate 3 ), the dominant eolor of the upper surface being a dusky olive tone, nearly uniform and little relieved by the inconspicnously red-tipuned fingers of the large claw. The ambulatory appendages have a romewhat bluich cast, and the ventral sulface of the ereature tends to a dull whitish tint. After the animal is placed in alcohol, a large, bright red, quadrangular pateh presently appears on the branchiostegites behind the corvieal groove, denoting that part of the shell which 
is most susceptible to the action of the liquid. After some hours the red colour extends orer the whole branchial region and for a time is sharply defined from the median areola and the other parts of the body, which still retain the dusky colour of the living animal. These striking colour-patterns resulting from recent immersion in alcohol might easily be mistaken for natural life colours by one who had not witnessed the change, and it suggests the probability that some writers have been misled into deseribing such colours as those of the living animal. Randall, for instance, in the Journal of the Academy of Natural Sciences of Philadelphia, 8, p. 138, Pl. 7 , describes and figures Astacus oregumus (= A. Icniusculus Dana?) as having a red spot on each side of the carapace, quite similar to the red spot which temporarily shows in Cambarus b. robustus recently immersed in alcohol. So, too, the whitish or lemon-yellow spot on the branchiostegites of Parastacus bimaculatus Philippi (Inales Universidad (hile, 87, p. 378), which is probably the same species that I described under the name Parastacus agassizii (cf. the colour description of this species by Prol. Carlos E. Porter in Revista Chilena de Historia Natural, 8, p. 258, pl. 9, fig. b) may possibly be the result of the action of alcohol on freshly killed specimens.

\section{Cambarus bartonil longulus (Cimard).}

New localitics:- West Virginia: West Fork of Greenbrier River, near Durbin, Pocahontas Co. (U.S. N. M., No. 23,992); Bluestone River, Lbb's Valley (U. S. N. M., No. 2S,61S).

In normal specimens of this subspecies the sub-orbital angle is hardly if at all prominent. The individuals which I mentioned in Proc. U. S. N. M., 12, p. 623, as having the orbit sharply defined below ly a proninent angle may prove to be, I suspect, C. bartonii longirostris. This form is not very well known as yet, and I have reason to think that it acquires with maturity a claw rery nuch like that of C. bartonii longulus. The character of the sub-ortital margin of the carapace seenrs to be very constant within the limits of a good sulmpecies, and it may prove to be the really diagnostic feature for separating $C . b$. longulus and C. b. longirostris.

Cambarts bartoni veteranus, subp. nov.

Plate 13, Fing. '?.

Rostrum long, without lateral teeth, margins elevated, strongly convergent, acumen triangular, terminating in an uptumed corneous tooth. Antero-lateral 
margins of the carapace destitute of any marked angle helow the eye. I small spine on each side of the carapace on the posterior edge of the cervical groove. Areola long and broad, $\frac{1}{4}$ as loroad as long, thickly strewn with impressed dots. Interior process of the epistome triangular. truncated anteriorly in old individuals. Clelas large, flattened, internal border fumished with a row of low tuberdes, with another row of ohsolesent ones rumning along beside them. The onter margin of the ehela is ridged, on acenunt of a marked longitudinal depression which rums along the distal part of the palm and the proximal part of the immobile finger. The fingers are long, hearily pitted, meeting only at their tips, leaving a wide gape between them. The carpus is anned with an internal median spine, and a very small intermal posterior spine: below it is furmished with the usual anterior median spine and a minute spinous tuberele between it and the internal median spine. The lower face of the merus is armed with a row of spines along its interual margin and an incomplete row on its external margin made up of about three at the distal end of the joint.

Length of a $\sigma^{\text {x form I., }} 93$ mm.; length of carapace 49 mm.; length of areoli, 17 mm.; width of areola, $4 \mathrm{~mm}$.; length of chela, $67 \mathrm{~mm}$, w width of chela, $26 \frac{1}{2} \mathrm{~mm}$.; length of daetylus, $45 \mathrm{~mm}$.

Type keality, Indian Creek, Baileysville, Iroming C'o., W. V'a.

Two males of the first form, sixteen males of the second form and seven fenales were collected by $\mathrm{Mr}$. WT. P. Hay at this place on the 16 th of August, 1900. They are in the collection of the U. S. National Museum, Nos. 25,020, $28,609,44,712$ (type).

There are also in the National Museum one male of the seeond form and two females (No. 28,619) from ('rane ('reek, IT. Vit., collected together with r. b. robustus on the Sth of Iugust, 1900, and one male of the first form from the Elk River, ('ogar's Mills, IV: Val.

This peculiar form of ('. burtomii resembles ('. b. longutus in the form of the rostrum, the wide gape of the fingers of the latge claw, and in the absence of a sub-orbital angle. In other respeets it is very dilferent from lomgulus, especially in the shape of the chela which is strongly depresised, with deep longiturlinal furrows at the base of the inmovable finger, both above and below, as in $C . b$. robustus, while in C. b. longulus the fingers are cylindrical and hearded within at the base. The characteristic gane of the fingers is not present in regenerated claws, which are furnished with very long straight fingers whose cut ting edges are straight and meet together thronghont their whole length. 
Cambarte bartonil asperimanes, subsp. nov.

Even as these pages are going to presir. two specimens of a peculiar, new race of $C$. bartonii are sent to me from the $L^{\top}$. s. National Museum, - males of the first form, collected by Messrs. P. C. Ftandley and H. C. Bolman in Flat Creek, near Montreat, Buncombe Co., N. C.. Sept. 1, 1913. C. bartomii fartomii was also eollected at the same time and place. The new form is conspicuously different from any previous y linown race of ( . bartoniz in having seattered coarse setae upon the chelae, which are moreorer deeply and coarsely pitted, with a tendeney toward corrugation; the inner border of the propodus is furnished with a cristiform row of from five to seven teeth; the dorsal face of the carapace is extrenely smooth and shows hardly a trace of the customary pits or impressed dots except a row along the margin of the rostrum; even on the areola the dots are scareely visible without high magnification; finally, the anterior process of the epistona is broadly trumeate in front.

Such are the diagnostic eharacters of this sub-species, which in other regards agrees pretty elosely with typieal (. bartomit. The hooks of the third segment of the third pair of legs are acute and attenuated at the tip.

Length, 54 mm., carapace, 27 mm.; chela, 19 mm. Type, U. L. N. M., No. 47,375 .

\section{Cambartes battonit acuminates Faxon.}

Cambarus arminatus FAxOx, P'ror. Anrr. Acal., 18S1, 20, P. 113

New localitics:- Marruad: Northwert Branch, Iyattsrille, Prince

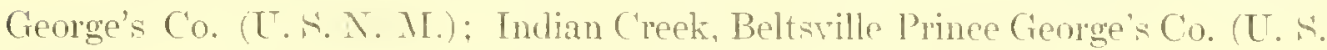

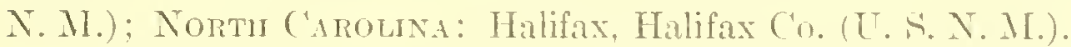

As noted abore under C'ambarus burtoniz mbustus, specimens from Fredericksburg, Ta. (M. C.Z., Nos. 3.615, 3,797) approach elosely to the form acuminatus and seem to exemplify a transition from robustus to acuminatus.

\section{Cambalits bartonil Laevis, subsp. nov.}

This form of $r$. burtomiz differs from the typical race in having the carapace smoother and less conspicuously punctated, the posterior section proportionately longer, being equal in length to the distance from the cervical gronre to the root of the eye-stallis; this lengthening of the hind section of the earapace involves a long areola which is also not merely relatively lut also absolutely 
narrower than in the typical C. bartonii; the areola is so narrow as to allow barely room for two closely approximated longitudinal rows of dots; the rostrum is a little longer than in C. bartonii, with more convergent margins and a longer acumen; the upper or superior border of the hand and movable finger are more distinetly tubereulate; the fingers are shorter, stronger, and nore heavily ribbed, and the outer border of the immobile one is more hearily and coarsely punctate. The posterior internal spine of the carpus is obsolete; the anterior process of the epistoma is more broadly triangular.

Type specimen, MI. C. Z., No. 3,812, W. S. Blatehley, Bloomington, Ind. $o^{7}$, form II. Measurements:- Length, fi $\mathrm{mm}$., length of earapace, $33 \mathrm{~mm}$., length of areola, $14 \mathrm{~mm}$., breadth of areola at middle, $1 \mathrm{~mm}$., Iength of right chela, $24 \mathrm{~mm}$., length of right dactylus, $16 \mathrm{~mm}$.

Other localities:- Fall Creek, Indianapolis, Ind. (M. C. Z., No. 3,796), New Albany, Ind. (M. C. Z., No. 3,618), Irvington, Ind. (U. S. N. M., Nos. 19,738, 22,204), May's Cave, Monroe Co., Ind. (U. S. N. M., No. 19,740).

The peculiarities of this crayfish, which appears to be a common form in the State of Indiana, were first pointed ont in my Notes on North American Crayfishes, Proc. U. S. Nat. Mus., 1S90, 12, p. 622. It has been described and figured, as C. bartonii, by Mr. W. P. Hay in the Twentieth Ann. Rep. of the Department of Geology and Natural Resomrees of Indiana, 1896, p. 437-489. The features which distinguish it from the typical form of $C$. bartonii are so pronounced as to render it necessary to mark it as a subspecies of $C$. bartonii if not as a valid species. In the great relative length of the posterior section of the carapace it resembles C. burtonii tencbrosus Hay from the Mammoth Care of Kientucky.

Aceording to letters which I received from Dr. Jolm Sloan of New Albany, Ind., in the year 1S83, this crayfish was always found by him in that region to be a denizen of standing ponds and still water, being replaced by $C$. slomii in the ruming streams. On the contrary, both Mr. W. P. Hay (l. c., p. 489) and Mr. A. M. Banta (The Fauna of Mayfield's Cave, Carnegie Inst. of Washington, Publ. No. 67, Nept. 1907, p. 73-75) aver that it is most commonly found in springs and small streams of clear rumning water where it seeks concealment under stones or in shallow burrows.

Messs. Hay and Banta have found this form a frequent inhabitant of the eaves of southern lndiana in company with the blind species, C. pellucidus. Those that dwell in the cares appear to attain a greater size than those in the surface waters, specincens in the Mitchell Caves, Lawrence Co., often exeeding 
$100 \mathrm{~mm}$. in length according to Banta, while those from the outside do not exceed St mm. A series of fifty-eight specimens from the ontside waters compared with a series of six specimens from Mayficld's Cave, Monroe Co., by Mr. Banta revealed the fact that the antennae of the cave specimens averaged $11.89 \mathrm{p}$. c. longer than the antennac of spomens taken outside the eaves in the immediate vicinity. The eave series was also lighter-coloured thin the series from above ground.

\section{CaMbarUS GRAYSONI, sp. hov.}

Cephalothorax rohust, posterior section high, flattened on the back and compressed laterally so that the sides are nearly vertical, giving to the whole section a subquadrangular aspect; shell densely punctated on the dorsal face, granulated on the lateral surfaces; distance from the tip of the rostrum to the cervical groove one and one half times the length from the cervical groove to the posterior end of the carapace; there are no lateral spincs upon the carapace and only the rudiments of the branchostegal spines; the areola is narrow (1.5) mm. broad at the middle in a specinen moasuring $21 \mathrm{~mm}$. from the cervical groove to the posterior horker of the earapace) with hut two rows of dots along the narrow part of its course; rostrum short, margins slightly convergent, nidelle exearated, acumen short, uptuned at the tip, withont lateral spines or teeth; post-orbital ridges low, without spines; sub-orbital angles well marked but blunt.

Abdomen as long as the cephalothorax, smooth, pleural angles rounded.

Chelipeds short in proportion to the hody; merns short, with bow tubereles near the distal end of the superior margin and spines hiserially arranged on the lower face; carpus deeply furrowed along the upper faee, armed with at prominent median internal acute thom or spine, one or two small tubereles in place of a median posterior spine; an inferior median spine, with sometimes a small tuhere between it and the interior median spine "ompletes the armature of the earpus; the chela is short, broat and triangular, articulated with the earpus in such a way as to assume a rertical position when flexed and to form with its fellow a shield or opereulum appressed to the front of the hody; this conformation of the chelae is a sure token of the bumbwing habits of this species; the inner (or superior) margin of the palm, is vert short, with a marginat row of five or six low tubereles; immediately within this row (which forms a serrate edge to the hand) is another row of similar though smaller tulberches, with vestiges of a few more irregularly disposed near the articulation of the ductylus; the fingers 
are rather short, strongly curved downward or inward, not conspicuously ribbed, their prehensile margins armed with rounded teeth, the free edge of the dactylus furnished with low, ciliated, squamous tubereles.

Antennal seale small, narrow. Anterior process of the epistome broad, truncate, anterior border concave, with a median tooth. Sexual organs of male and female similar to those of $C$. bartonii.

Dimensions of a femate specimen:- length, $113 \mathrm{~mm}$. length of cephalothorax, $54 \mathrm{~mm}$., breadth, $29 \mathrm{~mm}$., height of do., $21 \mathrm{~mm}$.; length of areola, $21 \mathrm{~mm}$, brealth of areola, $1.5 \mathrm{~mm}$; ; length of cheliped, $75 \mathrm{~mm}$.; merus, $21 \mathrm{~mm}$.; length of chela, $39 \mathrm{~mm}$; breadth of chela, $19 \mathrm{~mm}$.; length of dactylus, $24 \mathrm{~mm}$.

Bear Creek, a tributary of Green River, crayson springs, Cirayson Co., Ky., Oct. 24, 1874, F. W. Putnam coll. 1 mate of the second form, 3 females. NI. C. Z., No. 3,593.

This speeies is nearly related to C. ortmuni. Its form, like that of $C$. ortmanni, denotes a species of fossorial habits, but not so preëminently addicted to subterinean life as the speeies of the $C$. dingenes group, in which the cephalothorax suffers a greater lateral compression. Compared with C. ortmanni, C. graysoni is more depressed dorsally, more hearily punctated, the areola is broader (as broad as in the typical form of C.latimanus) the metathorax sonewhat shorter in proportion to the prothorax, the suborbital angle is much more salient, the anterion process of the epistoma is deeply cmarginate in front, with a prominent spine at the bottom of the emargination, the internal carpal spine is acute even in old and large examples, and the tuberetes of the inner (superior) margin of the hand are stronger and biserially disposed.

The speeimens which form the types of $C$. graysoni were referred to C. burtonii in my Revision of the Astacidae, p. (31, 159, 169. The peculiarities of the chetipeds, howerer, show that they behng to at distinct speeses, allied to $C$. ortmanni and ('. latimanus and forming together with these species a group connecting $C$. burtomii and its near allies with $C$. diogenes and the nearly related preeminently burrowing forms.

\section{Cambarús ortmanni Williamsom.}

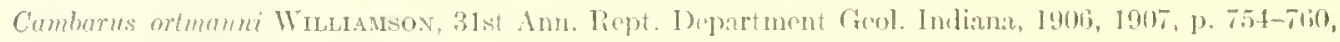
pl. 35.

Cambarus ortmunni, a burrowing species, was described by Mr. E. B. Williamson from sperimens captured in Wralls Co., Ind., in the Trabash River drainage near Bluffon. There has been al single female speeimen from ('incimati, O. 
however, in the Museum of Comparative Zoölogy since the early days of the Museum. This specimen, No. 243, was referred to C. bortonii hy Dr. Hagen in lis Monograph and entered into his computation of the variability of the wilth of the areola of that species, on p. 78. In my subsequent Rerision of the Astacidae, in 1885 , p. 64, I referred to this individual as possibly a peculiar species related to C. latimanus.

In the shape of the body and the narrow areola $C$. ortmanni bears a close resemblance to $C$. latimanus striatus, but in the outline of the rostrum and the sculpture of the claws it betrays a closer resemblance to C.bartonii. It is without doubt an immediate offshoot of the latter, modified by fossorial habits; the narrow areola, broad, conical claws, small antennal scale, long, narrow and quadrangular epistome, all denote this. It forms a passage from $C$. bartoniz to $C$. latimamus on the one hand and on the other to the more eminently fossorial forms, C. carolinus, C. diogenes, ete.

\section{Cambarus latimanus (Le Conte).}

There is a cotype, a dried male, in the Museum of Comparative Zoology, No. 3,378, acquired by exehange of types with the smithonian Institution in 1861; another cotype, a dried female, is preserved in the collection of the Arademy of Natural Seiences of Philadelphia. There are also in the Museum of Comparative Zoölogy, No. 236, preserved in alcohol, 3 males of the first form, 6 males of the second form, 3 females, and 7 young, eollected in Ithens, Gia., and sent to Professor Agassiz by LeConte in the 50's. These are essentially paratypes, and are of interest as fixing the type loeality, Athens, (a., which was not specified in Le Conte's original deseription of the speeies nor on the labels areompanying the type specimens in Cambridge and Philadelphia.

Two males, dried, M. C. Z., No. 3,366, sent by Prof. Lewis R. (iilhes from South Carolina as C. bartonii, without precise locality, are the only specimens reported from South Carolina so far as I know.

A small young female from Milledgeville, Ga. (M. C. Z., No. 3,365) and another from Roswell, Ga. (II. C. Z., No. 3,502) probably belong to this speeies.

Specimens from Blount spring and Cullman, Na. (U. S. N. M., No. 4,953, M. C. Z.. No. 3,639) differ from the typieal form in haring a narrower rostrum, and in specimens from Bridgeport, Ala., and Nickajack Care, Lshland City, and Nashrille, Tenn., the dirergence from the type is so pronouned that Mr. W. P. IIay has deseribed them as a subspecies, C. lutimanus striulus (1'poe. U. \&. Nat. Mus., 1902, 25, p. 437; type locality, Nashville, 'Tenu.). 
Mr. C. F. Baker has sent me a fine lot of C. latimanus from Auburn, Ala., among them specimens that have attained a length of four inches.

Cambares carolines Erichson.

This species was described in 1846 (Arch. Naturgesch., 12, 1, p. 96). Erichson's type, a male of the first form, is preserved in the Berlin Museum. It was collected by Dr. Cabanis, who assured Dr. Hagen that all the crayfishes that he collected in the United states eame from a rivulet in a plantation ealled Tiger Hall, near Greenville, S. C. ${ }^{1}$ In 1902 Mr. W. P. Hay procured from Dr. Johann Thiele of Berlin a photograph of the type speeinen together with drawings of the right elaw and first and second abdominal appendages. By means of this photograph and the drawings Mr. Hay identified the speeies with the crayfish which I described in 18St, from Cranberry Summit (now Terra Alta), Preston C'o., IT. Ya., under the amme of Cambaras dubrus see Hay, Proc. Biol. Soc. Washington, 15, March 5, 1902, p. 38.

By the courtesy of Mr. Hay I have before me Dr. Thiele's photograph and drawings of Erichson's type, and find that, although it nearly resembles $C$. dubius, yet it presents some different characters. 'The earpus is armed on its inner margin with two prominent, acute spines; of these the larger, anterior one is the so-ealled internal median carpal spine; on the left eheliped the photograph reveals a tuherde just behind, and at a lower level than, the median spine. In ('. dubius there is but one earpal spine, the internal median. Furthermore, the outer margin of the hand of $C$. corolinus, as shown in Dr. Thiele's drawing, is roumeded off and lacks the subserrate ridge characteristic of C. chubus; in this regard the hand of $('$. carolinus appears to be like that of $C$. monongalensis Ortm.

No. 14,314, U. S. N. M., male, form I., "among the Cherokees, James Momey," agrees (dowely with the pietures of Erichson's type, and may be consirlered a typical C.corolimus. In a notice of this specimen as $C$. dubius in 1890 (Proe. U. S. Nat. Mus., 12, p. 621), I erred in aseribing it to the Indian Territory. I an adrised by Mr. Mooney that it was in reality obtained in Swain Co. or in backson ('o., N. C., among the Eastern Cherokees, - a remnant of the Nation which eluded deportation in 1838 and still elings to the old home in western North

${ }^{1} \mathrm{Mr}$. W. W'. Hay ('moc. Biol. Soc. Washington, 15, p. 3\$, 1902) has unfort unately given this locality a western. Vorth Corolina, and has heen followerl in this error by Mr. J. 1. Harris (Kansas Univ.

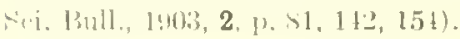


Carolina. ${ }^{1}$ It thus appears that Mr. Mooney's erayfish came from a region not far remote from the type locality of C. carolinus.

In this specimen (U. S. N. M., No. 14,314), which displays the normal features of $C$. carolinus, as I believe, the rostrum is narrower than in $C$. dubius and less quadrangular in outline; the anterior process of the epistoma is nuch broader and more triangular in outhe, the sides converging much more between the base and the truncated anterior angle; the earpus is armed with a prominent, acute, internal nedian spine, immediately behind which and at a little lower level lies a very small spiny tuberele; posteriorly to this, not far from the inmer articulation with the merus, lies another distinet spine, smaller than the internal median spine; the lower face of the carpus bears one tubercle about half-ray between the internal median spine and the outer articulation with the propodus; the lower face of the merus shows the biserial arrangement of spines as in $C$. dubius, as many as five or six spines adoming the external edge of the segment; the distal segment of the outer branch of the last pair of abdominal appendages is shorter and broader (less oval in contour) than in C. Aubius. The living rolor of this specimen, as is shown by a MS. note accompanying the specimen, was red, the color of $C$. dubius also.

A large number of specimens in the U. S. National Musenn collected at various places in the southwestern part of West Virginia (Nos. 28,591-28,596, 28,595-28,600, Horsepen Creek, War Creek, Baileysville, Lashneet, Barranche Creek), agreeing in most respects with the typieal C. dubius from northern West Virginia and Pennsylvania tend to develop the accessory carpal spines and tubereles of $C$. carolimus.

Three specimens (male, form I.) in the U. S. National Museum, No. 22,386, from a tributary of Stone River twenty miles from Colunbia in central Tennessee are interesting. They agree in most respects rith C.c. dubius, but the rostrum is a little narrower, with more convergent margins, the rostral acumen is less abrupt, and the outer border of the hand is rounded off without much indieation of serrature. In these regards the specimens agree with the typical carolinus; the carpus, however, is very smooth, boaring no spines exeept the internal median, as in C.c. dubius. The outer inferior row of spines on the merus is present, though slightly developed. The branchio-cardiae lines are in closer contact than in any other specimens of this species that I have seen, reducing the areola to a narrow line.

See Myths of the Cherokee, hy James Mooney, Ninetenth Inn. Ropt. Burean Amer. Ethnul. $1897-98,1900$, p. 308. 
The elosely related Bhe or Monongahela Crayfish was first discovered at Pittsburgh, Pa., in 1S9S, by Mr. E. B. Willimmson. Specimens were sent to me in the month of August of that year, which appeared to me to be a local form of $C$. dubius, and they were reeorded as such by $M L$ r. Williamson in a paper on the Crayfish of Allegheny, County, Pemsylvania (Anu. Carnegie Mus., 1901, 1, p. 11). Compared with the type of $C$. dubius these speeimens showed a narrower rostrum with less pronounced angles at the base of the acumen; the outer border of the hand was evenly rounded, not ridged, and destitute of the imperfect scrature seen in $C$. dubius, where this feature results from the regular row of transversely elongated marginal punctations giving to the margin a milled appearanec; further, the carpus of the Pittsburgh form was armed with several aceessory spines and tubereles, besides the prominent internal median spine which is all the armature of the carpus in $C$. dubius.

In a paper on the C'rawfishes of western Pennsylvania published in 1905 (Ann. Cannegie Mus., 3, No. 2) and in a more elaborate memolr which appeared at the close of the following year (The Crawfishes of the State of Pennsylvania, Mem. Carnegie Mus., 2, No. 10), Dr. 1. E. Ortmann showed that the Blue ('rayfish and C. dutrus both lived in western Pennsylvania, that they ocenpied different areas separated by the Chestnut Ridge, a range of hills on the west of the Allegheny Mountains, the Blue Crayfish (to which he gave the name C'ambarus monongalensis) being found on the hilk lying on the west of this range while $($. dubius lived in the mountain region to the east of Chestnut Ridge, between it and the principal range of the Mllegheny Mountains. Dr. Ortmann also hrought ont rolorly, as a result of extensive field study, the eolor-differenee between the two forms, the dominant color of C. dubius being red, of C. monongulensis blue. The range of the latter form appears to be rather narrow, being restricted, as fur as is shown by Dr. Ortmann's most interesting investigations, to Westmoreland, Allegheny, Beaver, Washington, Fayette and (ireen Counties, P'a., and Hancock, Brooke, Ohio, Marshall and MLnomgalia Counties, IV. Va., at altitules ranging from 800 feet to 1200 feet above the sea-level.

Dr. Ortmam eompared his specimens of $r$. monongalensis with the northern race of $c^{\prime}$. corolinus, $i$. e., C. Aubius Fax., and came to the conclusion that they represented a distinet species. But as appears from what has been said above, three of the characters which Ortmann thought were peculiar to C. monongalensis are also present in the southern, typical form of $C$. carolinus, viz., the narrower rostrum, non-serrated onter margin of the hand, and the presence of more than one spine on the inner side of the carmus. There are thus left but two features 
to separate $C$. monongalensis from $C$. carolinus, viz., the uniserial disposition of the spines on the lower face of the merus of the cheliped, and the colour.

So, with a broader overlook of the geographical variations of these interesting forms it would seem to be more logical to eonsider C. curolimus Erichs., C. dubius Fax. and C. monongalensis Ortm. as three gengraphical laces, or subspecies of one species. The three subspecies may be distinguished by neans of the subjoined key:-

Lower face of mertis with only one row of spines develuped. Colour, blue

C. rarolimus monongulensis (Ortm.)

Lower face of merus with two rows of spines devetoped. Colour, red.

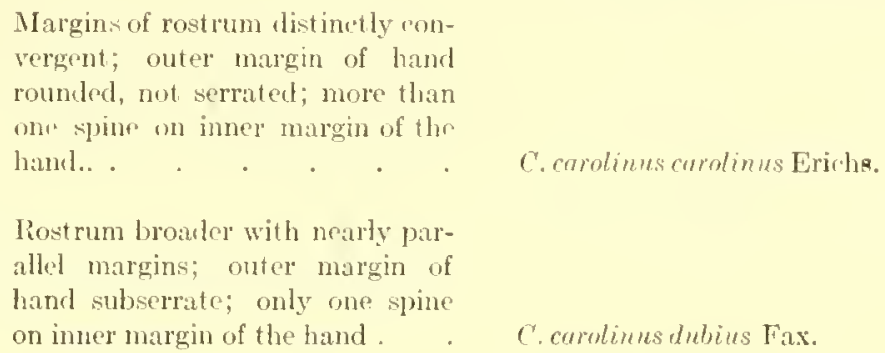

The geographical range of $C . c$. monongalensis, so far' as it has been worked out by Dr. Ortmann, has been given above. Nore exploration is needed to elucidate the dispersal of the typical $C$. carolinus. The type locality is near Greenville, Greenville Co., S. C. The specimen in the U. S. National Museum, collected by James Mooney and described above, came from Swain or Jackson Co., western North Carolina. Ortmann (Mem. Carnegie MLus., 2, p. 397) mentions some specmens in the Academy of Natural Sciences of Philadelphia, collected by Prof. J. P. Moore at Blowing Rock, Watauga Co., N. C., which have a narrower rostrum than C.c. dubius, and are therefore probably $C . c$. carolimus.

Specimens collected by Mr. H. G. Hubbard at Pennington's Gap, Lee Co., Va. (M. C. Z., No. 3,489) and by myself at Cumberland Ciap, at the junction of the three states of Virginia, Tientucky and Tennessee (M. C. Z., No. 3,594) are too young to deternine sulspecifically with assurance, but they appear to be C. c. dubius. The form spread over the southwestern parts of West Virginia, as has been pointed out (p. 397) is more or less intermediate between carolimus and dubius, white the pure $C . c$. dubius has been reported from Westmoreland, Fayette, and Somerset Cos., Pa., Garrett Co., Md., and Preston, Tucker, and Mineral Cos., IT. Ta. 


\section{Cambarus diogenes Girard.}

Nen loculities:-- Marriand: Lamel, Prinee Georges ('o. (U. S. N. M.). Themena: Dismal swamp (U. .. N. M.). Nomtu Carouna: Near Beaufort, Carteret Co. (Coll. W. P. Hay). Alabama: Auburn, Lee Co. (M. C. Z.). Mississipre: Muldom, Monroe Co. (U.S. N. M.); Agrieultural College, Oktibbehal Co. (U.S. N. M.). Ohro: Toledo, Lueas Co. (U.S. N. M.). Indias: Near Milltown, ('rawford Co. (U.S. N. M.); Lake Maxinkuckee, Marshall Co. (U.s. N. M.); Whito Co. (U. S. N. M.). Ilusnors: Wabash Co. (U. S. N. M.); Henderson Co. (U. .. N. M.); near Olney, Riebland Co. (U. .. N. M.). Iows: Burlington, Des Moines ('o. (U.S. N. M.). MICnigan: Raisin River,

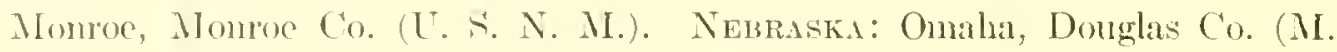
('.l.); Creighton Creck, soutl of Niobrara, Knox Co. (U.S. N. M). ColoRano: Fort (ollins, lorimer Co. (M. C. Z.).

Knox Co., Indiant, given as a station for ( $`$. diogenes in my Revision of the Astacidae, page 71 , should be transferred to C. argillicola, p. 77.

\section{Canbalits blogenes ludovicianus Faxon.}

Nen lecrlitirs:- Frierson, De Soto Co., La.; Rosedale, Bolivar Co., Miss.; T. .. N. il.).

\section{Cambarus argilicola Faxoll.}

N'cu localitis:- Olney, Richland Co., Ill. (U. S. N. M.); Frierson, De soto C'o., La., in burows 18 inches deep, surmounted by low mud "chimneys" (U. S. N. M.).

\section{Cambartes uilleit Faxoln.}

Mr. IV. P. Hay captured one speeimen of this speeies near Beanfort, N. C., lug. 17, 1912. This specimen, a fenale, was taken from a bole in the bank of a pond on the south side of Alley's C'reek, about fourteen miles north of Beaufort. On the other side of the same ereek, abont a mile away, Mr. Hay collected three speeimens of $r$. diogenes (also females) in holes on the edge of a swamp. The specimon of $C$. uhleri differs from the type speeimens from Maryland but very slightly, the rostrum being a trifle more coneare above, and the foreola at the base of the rostrum lather more promoumed.

Chler's ('rayfish has heretofore been known only from the tidewater Oeean and Bay comntios of eastern Maryland. 
Cambarus clypeatus Hay.

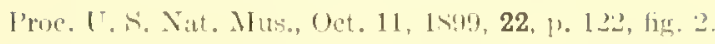

The type specimen of this species, a female, U. . . Nat. MLus, No. 17,277, is the only one known. It was found by Mr. G. A. Coleman, of the U. F. Biological Survey, in April, 1892, in a stiff at Bay st. Iouis, Miss. Mr. Hay surmises that it belongs in the neighbourhood of C cubensis; I should incline rather, on account of the structure of the amnulus ventralis and the shape of the body, to place it in C. bartonii group. 
1.I'l OH THE DESCRIBED SPECIES OF CRAYFISHES (PARASTACIDAE IND ASTACIDAE).

PARASTACIDAE.

Astacopsis Huxley.

Istacopsis Tluxley, Proc. Zool. soc. Lundon, 1s7s, p. 7tit.

1. Astacopsis franklinit.

Istacus frontimii Ciray, Eyre's Journals of Expeditions of Discovery into C'entral Australia, 1845, 1, p. 409.

Type locality:- Tasmania.

2. Istacopsis NOBILIs.

Astacoüdes nobitis Dana, Crustacea U. S. Expl. Exped., 1852, 1, p. 526.

Type locality:- New South Wales?

8. ISTACOOSIS SPINIFERA.

Cancer serratus Shaw, Zoölogy of New Hollaud, 1794, pl. S, (nec Caneer serolus Forstil, 1775).

PAstacus australasiensis Milne Edwards, Hist. Nat. Crustacés, 1837, 2, 1. 332. Type locality:- Sydney, Australia. Two cotypes, 1'aris Mus.

Astueus anstratiensis Erichson, Arch. Naturgeseh., 1846, 12, 1, p. 94 (nom. (mend.).

Astacoüdes spinifor Heller, Reise der Novara, Zool. Th., 2, pt. 3, Crust., 1865, p. 102.

Astarus armatus Martens, Inn. Mag. Nat. Ilist., 1S66, ser. 3, 17, p. 359. Type locality: - Murray River, Australia. Type, Berlin Mus.

Astacopsis mumattonsis Bate, Rept. C'hallenger, 24, Crust. Macrura, 1sss, p. 202. Type locality:- Paramatta River, Sydney, Australia. Type, Brit. Mus., 1 o.

?.1stacopsis sydneyensis 13ate, Rept. Challenger, 24, Crust. Maerura, 1Ss8, p. 204. Type lorolity:- Syduey, Australia. Type, Brit. Mus., 1 o .

Type loculity:- Australia.

\section{Ineertae Sedis.}

1. Antacopsis? Themanicus.

Astucus tasmanicus Erichson, Aprh. Naturgesch., 1St6, 12, 1, p. 94.

Type loculity:- Tasmania. Type, Berlin Mus., No. 1,579, \&. 


\section{CHERAPS Erichson.}

Cireraps Erichson, Arch, Naturgench., 1st1i, 12, 1, p. 101.

1. Cheraps preissis.

Astacus (Cheraps) preissii Erichson, Areh. Naturgesch., 1846, 12, 1, p. 101. ?Astacoüdes plebejus IIess, Areh. Naturgesch., 1865, 31, 1, p. 164. Type locality:- Sydney, Australia. Type, Göttingen Mus.

Type locality:- Southwestern Australia.

2. Cheraps bicarinatus.

Astacus bicarinatus Gray, Eyre's Journals of Expeditions of Discovery into Central Australia, 1845, 1, p. 410.

Type locality:- Port Essington, North Australia.

3. Cheraps quadricarinatus.

Astacus quadricarinatus Martens, Monatsber. Mkad. Wissensch. Berlin, 1S6S, p. 617.

Type locality:- Cape York, Australia. Type, Berlin Mus., No. 2972.

4. Cheraps quinguecarinatus.

Astacus quinquecarinatus Gray, Eyre's Journals of Expeditions of Discovery in to Central Lustralia, 1845, 1, p. 410.

Typc locality:- Western Australia, near Swan River.

ENGIEUS Erichson.

ExGaters Erichson, Arch. Naturgesch., 1s 16, 12, 1, p. 102.

1. Engaeus fossor.

Astacus (Engaeus) fossor Erichson, Arch. Naturgesch., 1846, 12, 1, p. 102.

Type locality:- Tasmania. Types, Berlin Mus. Nos. 1123, 1124.

2. Engaeus cunicularius.

Astacus (Engaeus) emicularius Erichson, Arch. Naturgesch., 1846, 12, 1, p. 102 .

Engaeus cunienlaris Haswell, Cat. Australian Stalk-and Sessile-eyed Crustacea, 1882, p. 179. (Err.typograph.?)

Type locality:- Tasmania. Type, Berlin Mus., No. 1122.

Paranephrops Thite.

Paraxephrops White, Gray's Zoul. Miscell., June, 1812, p. 79.

1. Paranephrops planifrons.

Paranephrops planifrons Whitc, Gray's Zoöl. Miscell., June, 1S42, p. 79. 
PParanephrops temuicomis Dana, Crustacea U. S. Explor. Exped., 1852, 1, 1. 527. Type locality: - Fresh-water streams about the Bay of Islands, North Island, New Zealand.

Type Ineality: - River Thames, North Island, New Zealand. Types, Brit. Mus.

2. Paranephrots zealandicus.

Astacus zcalandicus White, P'roc. Zoöl. Soc. London, 1847, part 15, p. 123.

Paranephrops neo-zclanicus (hilton (in part), Trans. and Proc. New Zealand Inst., 1885, 21, p. 249 (nom. cmend.).

Type locality: - New Zealand. Typcs, Brit. Mus.

3. Paranephrops sletosus.

Parancplorops setosus Hutton (in part), Ann. Mag. Nat. Hist., Nov. 1873, ser. 4,12, p. 402.

Paranephrops horridus "S[emper?] MS.," Miers, Cat. Stalk and Sessileeyed Crust. New Zealand, 1876, p. 73. (nom. nudum). Brit. Nus.

PAstacoüdcs tridentutus Wood-Mason, Proc. Asiatic Soc. Bengal, 1876, p. 4. Type lncality: - New Zealand.

Type locality: - River Aron, near Christehurch, Fouth Island, New Zealand.

Astaconephrops Nobili.

Astaronephrops Nolili, Annali del Mus. Civ. Storiz Nat. Genova, 1899, 40, p. 24.

1. Astaconepirops aliertisil.

Astrenneplerops albertisii Nobili, Ammali del Mus. Civ. Storia Nat. Genova, 1899,40, r. 244.

Type locality: - Katau, southem New Guinea. Type, Genova Mus., 1 o .

AstacoÏDes Guérin.

Istacoïdes Guérin, Revue Zoologique, 1839, 2, r. 109

1. AstaCoİdes MadaGascariensis.

Astucus madugascariensis Aud. et M. Edw., Journ. de l'Institut, 1839, p. 152.

Astucoüdes gondotii Ciuérin, Revue Zoologique, 1839, 2, p. 109. Type locality:- Madagascar. Type, Ačal. Nat. Sei. Philad., Ciuérin Coll., No. 290. 
Astacus caldwclli Bate, Proc. Zoöl. Soc. London, 1865, p. 469. Type locality:- Near Antananarivo, Madagascar.

Type locality: - Madagascar.

\author{
Parastacus Huxley. \\ Parastaces Huxley, Proc. Zoöl. Soe. London, 1878, p. 77I.
}

1. Parastacus pilmanus.

Astacus pilimamus Martens, Arch. Naturgesch., 1869, 35, 1, p. 15.

Type locality: - Porto Alegre, Brazil. Types, Berlin Mus., Nos. 3,323, 3,447 .

2. Parastacus mrasiliensis.

Astacus brasilicnsis Martens, Arch. Naturgesch., 1869, 35, 1, p. 16.

Typc locality: - Porto Mlegre, Brazil. Types, Berlin Mus., Nos. 3,322, 3,448 .

3. Parastacus defossus.

Parastacus defossus Faxon, Proc. U. S. Nat. Mus., Feb. 17, I898, 20, p. 686.

Type locality: - Montevideo, Uruguay. Types, U. S. N. M., No. 19,647; paratype, M. C. Z., No. 4,776 .

4. Parastacus saffordi.

Parastacus saffordi Faxon, Proc. U. S. Nat. Mus., Feb. 17, 1898, 20, p. 683.

Type locality: - Montevideo, Uruguay. Typcs, U. S. N. M., No. 12,581; paratype, M. C.Z., No. 4,775.

5. Parastacus varicosus.

Parastacus varicosus Faxon, Proc. U. К. Nat. Mus., Feb. 17, 1898, 20, p. 685.

Type localily: - Colima, Mexico (by eror?). Typc, U. S. N. M., No. 4,133.

6. Parastacus chillensis.

Astacus chilensis MI. Edw., Hist. Nat. des Crustacés, 1S37, 2, p. 333.

Type locality: - Coasts of Chile. Typc, Mus. Hist. Nat. Paris.

7. Parastacus mimaculatus.

Astacus bimaculatus Philippi, Inales Universidad Chile, 1894, 87, p. 378.

Parastacus agassizii Faxon, Proc. U. S. Nat. Mus., Feb. 17, 1898, 20, p. 690. Type locality: - Talcahuano, Chile. Typcs, M. C. Z., No. 3,400; paratypes, U. S. N. M., No. 12,045.

Type locality: - Chile. 
8. Parantaces spinifrons.

Astacus spinifrons Philippi, Inales Universidad Chile, 1882, 61.

Type locality: - Cliile.

9. Parastares nicoleti.

Astecus chilcnsis Nicolet (nec M. Edw.), Gay's Hist. ('hile, Zool., 1S49, 3, p. 211. Type locality: - Chile.

Astacus nicoleti Philippi, Anales Universidad Chile, 1582, 61.

Type locality: - C'hile.

10. Parastacus hassleri.

Purastacus hassteri Faxon, Proc. IT. S. Nat. Mus., Feb. 17, 1898, 20, p. 687.

Type locality: - Talcahuanó, Chile. Types, M. C. Z., No. 3,401; paratypes, U. S. N. M., No. 19,689.

11. Parastaces araucanius.

Parastacus araucanius Faxon, supra, p. 353.

Type locality: - Corral, Chile. Type, M. C. Z., No. 7,355.

Astacus Fabricils.

Astaces Fibricius, Sirst. Entomol, 1775, p. 113.

1. Astacus colchicus.

Astrens colchicus Liessler, Bull. Soc. Imp. Moscou, 1876, 50, p. 2.

Type locality: - Upper Rion River and tributaries, Transcaueasia.

2. ISTACUS PaCHYPUS.

Astacus puchyms Rathke, Ifim. Aciul. Imp. St. Peftersourg, 1836, 3, p. 365.

Astacus casprus Eichwald, Bull. Noo. Imp. Moseou, 1838, p. 149. T'ype loculity: - Caspian Fea, near Baku.

Type locality: - Neighborhood of Nikolaiev, Bong River, Russia.

3. Astaces leptodactylus.

Astreus leptollactylus Eschscholtz, Mém. Soe. Imp. Mloseou, 1S23, 6, p. 109. Astacus lcptodactylus salinus Nordmann, Obscrvations sur la Fame Pontique, in Demidof's Voyge dans la Russie Néridionale et la Crimée, Atlas, Crustacea, 1842, Tal). 1. Type locality: - Blaek Sea.

Type locality: - crovermment of Taurida, Russia. 
3a. Astacus leptodactylus caspius.

Astacus leptodactylus, var. caspia Eiehwald, Bull. Soc. Imp. Moseou, 1838, p. 148 .

Type locality: - Caspian Sea, near Lenkoran.

3b. Astacus leptodactilus angulosus.

Astacus angulosus Rathke, Mém. Lead. Imp. St. Pétersbourg, 1S36, 3, p. 364 .

Type locatity: - Crimea, Russia.

4. Astacus Kessleri.

A stacus kessleri Sehinkewitseh, Bull. Soe. Imp. Amis Hist. Nat. Moseou, 18s6, 50 (Proe. Zool. Sect., 1, pt. 1, p. 20).

Type locality: - Near the town of Turkestan, Covernment of syr-Darya, Asiatic Russia.

5. Astacus astacus.

Cancer astacus linné, Fyst. Nat., Ed. 10, 1758, 1, p. 631.

Astacus flumatilis Fabr., Syst. Entomol., 1775, p. 413. Typc locality: Europe.

Cancer nobilis Schrank, Famna Boiea, 1803, 3, 1 Ahth., p. 246. Type locality: - Bararia.

Astacus fluiatilis communis Gerstfeldt, Mém. Arad. Imp. St. Pétersbourg, 1859, 9, p. 554. Type locality: - Europe.

Type locality: - Europe.

6. Astacus pallipes.

Astacus pallipes Lereboullet, Mém. son. Aci. Nat. Strasbourg, 1858, 5, p. 7.

Astacus fontinatis Carhonnier, L'Éerevisse, 1869, p. 8. Type locality:France.

Type locality: - In canals and ditehes, Strasbourg, Alsace.

6a. Astacus rallipes fuldisianus.

Astacus pallipes, val. fulcisiana Nimi, Atti Sor. Ital. Áci. Nat. Milano, 1886,29, p. 326 .

Type locality: - Province of Belluno, Italy.

6b. Astacus pallipes italicus.

Astacus pallipes italicus Faxon, supra, p. 361. 
Type locality: - River Sarno, Pompeii, Italy. Types, U. S. N. M., No. 28,638; paratypes, M. C. Z., No. 7,409.

7. Astacus torrentium.

Cancer torrentium Schrank, Fauna Boiea, 1S03, 3, 1 Abth., p. 247.

Astacus saxatitis Koch, Deutschlands Crustacen, Myriapoden und Arachniden, 1835\%?, 7, No. 1 (Panzer and Herrich-S'chäffer's Dentschlands Insecten, 140, No. 1). Type locality: - Bavaria, in mountain brooks of the Oberpfalz and also in the Danube under stones.

Astacus tristis Koch, Deutschłands Crustaceen, Myriapoden und Arach niden, 1S35?, 7, No. 2 (Panzer and Herrich-Śchüffer's Deutschlands Insecten, 140, No.2). Type Locality: - Bararia, in a momutain brook at Bodenstein, Regen River system.

Aslucus tongicomis Lereboullet, Mém. Soc. Sci. Nat. Strasbourg, 185S, 5, p. 2. Type locality: - Ill and Bruche Rivers, Mlsace.

Type locality: - Bavaria, in stony streams and also in lakes, e. g. Würm-See.

8. Astacus gambeli.

Cambarus gambelii Girard, Proc. Acad. Nat. Sci. Philad., 1S52, 6, p. 90.

Type locality: - "California." Types, Acad. Nat. Sci. Philad.

Sa. Astacus gambelil connectens.

Astucus gambelii conncetens Faxon, supra, p. 360.

Type loculity: - Snake River, Upper Sahmon Falls, Idaho. Type, U. s. N. M. No. 23,096; paratype, M. C. Z., No. 7,385.

9. Astacus Nigrescens.

Astacus nigrescens Stimpson, Proc. Boston Soc. Nat. Hist., Feb., 1857, 6, p. 87.

Type locality: - Neighborhood of San Francisco, Cal. Types probably destroyed in the Chicago fire in 1871.

9i. Astaces nigizescens fortis.

Astacus nigrescens fortis Faxon, supra, p. 360.

Type locality: - Fall River, Fall City Mills, Shasta Co., Cal. Type, U.S. N. M., No. 44,404; puratypes, M. C. Z., No. 7,3S3.

10. Astacus trowbridgit.

Astucus trowbridgii Stimpson, Proc. Boston Soc. Nat. Hist., Feb., 1857, 6, p. 87 . 
Type locality: - Columbia River above Istoria, Oregon. Cotypes, U. S. N. M., No. 2,080; M. C. Z., No. 3,510; Bost. Soc. Nat. Hist.; Peabody Mus. Yale Univ.

11. Astacus leniusculus.

Astacus leniusculus Dana, Crustacea U. S. Expl. Exped., 1852, 1, p. 524.

?Astacus oreganus Randall, Journ. Acad. Nat. Sci. Plilad., 1840, 8, p. 138. Type locality: - Columbia River. Type destroyed.

Type locality: - Columbia River and Puget's sound. Cotype, U. S. N. M., No. 2,019, and probably No. 2,161.

12. Astacus klainatiensis.

A stacus lilamathensis Stimpson, Proc. Boston Soe. Nat. Hist., Feb., 1857, 6, p. 87 .

Type locality: - Klamath Lake, Oregon. Type probalsly destroyed in the Chicago fire in 1871.

\section{CAMBAROIDES Faxon.}

Cambaroüdes Faxon, Proe. Amer. Araul, 1884, 20, p. 150.

1. Cambaroïdes Japonicus.

Astacus japonicus De IIaan, Crustacea of Siebold's Fauna Japonica, 1S42, p. 164 .

Type locality: - Japan.

2. Cambaroïdes similis.

A stacus (Cambaruïdes) simitis Koelhel, Anz. Akad. Wissensch. Wien, math.nat. Classe, 1892, 29, p. 176; Sitzungsber., 1892, 101, pt. 1, p. 650.

Type locality: - Provinee of Kjöng-Kíur-do, Korea.

3. Cambaroïdes dauUricus.

Astacus duuricus Pallas, Apicilegia Zoologica, 1772, Fase. 9, p. 81.

Astacus leptorthinus Fischer, Bull. Soc. Inmp. Moscou, 1836, 9, p. 467. Type locality: - Dauria. Types, St. Petersburg Mus.

4. Cambaroüdes schrenckit.

Astacus schrencliii Kessler, Bull. Soc. Imp. Moseou, 1874, 48, p. 361.

Type locality: - Iower Amur River Basin.

1. $I$., were there when the specins was described. 
CAMB IRUS Erichson.

\author{
Cambarus Erichson, Arch. Naturgesch., 1846, 12, 1, p. S8.
}

\$. Third segment of the third pair of legs of the male furnished with hooks. First pair of abdominal appendages of the male stout, inner and outer parts elosely appressed, laterally compressed, with a horny (in the first form) spine at the tip; anterior margin with a prominent shoulder near the distal end. (Subgenus Procambarus of Ortmann.)

1. Cambartes digueti.

C'ambans digueti Bouvier, Bull. Mus. Hist. Nat. Paris, 1897, 3, p. 22.5.

Cambarus carinatus Faxon, Proc. U. S. N. M., Feb. 17, 1S98, 20, p. 648. Type loenlity: - Cuadalajara, Mexico. Type, U. .. N. M., No. 17,699, 1 б f. 1; paratypes, I'. S. N. MI., No. 16,085 (Ameea, State of Jaliseo, Mex.), 17,707 (Hacienda de Villachuato, State of Miehoacan, Mex.); M. C. Z., No. 4,338 (Imeca, Mex.).

Type loeality:- Affuents of River Santiago, State of Jalisco, Mexico. Cotypes, Mus. Hist. Nat. Paris; U.S. N. MI., No. 30,579; Carnegie Mus. Pittsburgh.

2. ('ambarus wiliamsont.

Cambarus (Procambarus) williamsoni Ortmann, Innals Camegie Mus., 1905,3, p. 439 .

Type locality: - Los Amates, Province of Izabal, Guatemala. Types, Carnegie Mus. Pittsburgh.

3. Cambarus pilosimanus.

Cambarus (Procambarus) pilosimamus Ortmann, Proc. Washington Acad. Sé., Мау 3, 1906, 8, p. 6.

Type locality: - Coche, near Coban, Cuatemala. Types, MIus. IIist. Nat. Paris; pratypes, Carnegio Mus. Pittshumgh (1 o f. 1., 1 \%).

4. CaMBALUS MEXICANUS.

Astacus (Cambarus) mexicanus Erichson, Areh. Naturgesch., 1S40, 12, 1, p. 99.

Cambarns aztceus Saussure, Rer. et Mag. Zool., 1857, ser. 2, 9, p. 503. .Type locality: - Tomatlan [State of Vera Cruz:] Mexieo. Cotypes, (ienera Mus.: U. S. N. M., No. 20,682 (1 o ex Cienera Mus.).

Cambarus ruthemi Pearse, 13th Rept. Nich. Acad. Sci., 1911, p. 110. Type locality: - Cuatotolapam, Canton of Ieayuean, State of Vera C'ruz, Mexieo. Types, Mus. Univ. Michigan, No. 41,704, 41,705, 1 ァ, 1 ㅇ.

Type locality: - Mexico. Type seemingly lost from the Berlin Mus. 
5. Cambarus cubensis.

Astacus (Cambarus) cubensis Erichson, Arch. Naturgesch., 1S46, 12, 1, p. 100 .

Type locality: - Cuba. Type, Berlin Mus.

5a. Cambarus cubensis consobrinus.

Cambarus cubensis consobrinus Sanssure, Rev. et. Mag. Zool., 1857, ser. 2, 9, p. 101 .

Type locality: - Ponds in the central part of Cuba. Cotypes, Ciencra Mus. $\left(\begin{array}{ll}2 & \sigma^{7}\end{array}\right)$; Mus. Hist. Nat. Paris ( $\left.\sigma^{7}\right)$; Berlin Mus. (2 q); U. S. N. M., No. 20,684 (1 o $^{7}$ ex Geneva Mus.).

5b. Cambarus cubensis Rivalis.

Cambarus cubensis rivalis Faxon, Bull. M. C. Z., October, 1912, 54, p. 459 .

Type locality: - San Diego de los Baños, Province of Pinar del Rio, Cuba. Type, M. C. Z., No. 7,406.

6. Cambarus atkinsoni.

Cambarus (Procambarus) athinsoni Ortmann, Annals Carnegie Mus., May 5, 1913,8, p. 414.

Type locality: - Tributaries of Rio de los Indios, Los Indios, Isle of Pines. Types, Carnegie Mus. Pittsburgh, No. 74,924.

$\S$ II. Third segment of third pair of legs of the male provided with hooks. First pair of abdominal legs of the male truncate, outer part closely applied to the imer and armed at the tip with from one to three horny, recurved teeth; inner part ending in a sharp spine generally directed outward. (Subgenus Cambarus of Ortmamn, in part.)

7. Cambarus bouvieri.

Cambarus (Cambarus) bourieri Ortmann, Ann. Sci. Nat., 1909, sér. 9, 7, p. 159.

Type locality: - Uruapan, Michoacan, Mexico. Cotypes, Mus. Hist. Nat. Paris (2 or f. I., 1 o ); Carnegie Mus. Pittsburgh (1 ơ f. I.).

8. Cambarus simulans.

Cambarus simulans Faxon, Proc. Amer. Acad., 1S\$1, 20, p. 112.

Cumbarus gallinus Cockerell and Porter, Proe. Acad. Nat. Sci. Philad., 1900, 
p. 434. Type locality: - Gallinas River at Las Tegas, N. Mex. Types, U. S. N. M., No. 23,916; paratypes, M. C. Z., No. 7,342; Acad. Nat. Sci. Philad.

Type loeality: - Dallis, Texas. Types, M. C. Z., No. 3,646; paratypes, M. C. Z., No. 3,647; U. .. N. MI., No. 4,150; st. Petersburg Mus.

9. Cambarus gracilis.

Cambarus graeilis Bundy, Bull. Illinois State Lab. Nat. Hist., Dec. 1876, 1, p. 5 .

Type locality: - Normal, McLean Co., Ill., and Racine, Racine Co., Wisconsin. Cotypes, Ill. State Lab. Nat. Hist., Urbana, Ill.; M. C. Z., No. 3,794 (Normal, Ill.), No. 3,454 (Raeine, Wis.).

10. Cambarus hagenianus.

Cambarus hagenianus Faxon, Proe. Amer. Acad., 1S54, 20, p. 141.

Type locality: - Charleston, S. C. Type, M. C. Z., No. 232 (1 శ̋ f. I.).

11. Cambarus advena.

Cambarus adrena LeConte, Proe. Aead. Nat. Sci. Philad., 1855, 7, p. 402.

Type loeality: - Lower Georgia. Cotypes, MI. C. 7., No. 3,379; Acad. Nat. Sei. Philad.

\$II. Third segment of third and fourth pairs of legs of the male furnished with a hook. First pair of abdominal appendages of male truneate, outer part closely applied to inner part and armed at the end with from one to three horny recurved teeth; inner part ending in a sharp spine which is often directed outward. (Subgen. Cambanus of Ortmann in part.)

12. Cambarus spiculifer.

Astacus spieulifer le Conte, Proc. Aead. Nat. Sci. Philad., 1855, 7, p. 401.

Type loeality: - Athens, Clarke Co., Georgia. Cotypes, N. C. Z., No. 3,376 (1 of f. I.); Aead. Nat. Sci. Philad. (1 or f. II); paratypes, M. C. Z., No. 172 (11); U.S. N. M., No. 4,962 (1 ơ); MIus. Hist. Nat. Paris (2).

13. Cambarus versutus.

Cambarus versutus Hagen, Mem. M. C. '/., 1S70, 2, p. 51.

Type locality: - Spring Hill, Mobile Co., Ma. Types, M. C. Z., No. 190; paralypes, U. A. N. M., No. 4,963, (1 o ); Mus. Hist. Nat. Paris (2); Australian Mus., sydney.

14. Cambarus pubescens.

Cambarus pubescens Faxon, Proc. Amer. Acad., 1S\$4, 20, p. 109. 
Type locality:-McBean Creek, Augusta, Georgia. Types, U. S. N. M., No. 3,181 (1 아 f. II., 1 o ); paratypes, M. C. Z., No. 3,551 (2 q).

15. Cambarus angustatus.

Cambarus angustatus LeConte, Proe. Acad. Nat. Sci. Philad., 1855, 7, p. 401.

Type locality: - Lower Georgia, in streams of clear water, between sandhills. Type, Acad. Nat. Sci. Philad. (1 o7 f. I.).

16. Cambarus lecontei.

Cambarus lecontei Hagen, Mem. M. C. Z., 1S70, 2, p. 47.

Type locality: - Mobile, Ala. Types, M. C. Z., No. 217; paratypes, U. S. N. Ml., No. 4,958; Mus. Hist. Nat. Paris (2); Mus. Würzburg (2); Mus. St. Petersburg (2); Australian Mus., Sydney.

17. Cambarus blandingit.

Astaeus blandingii Harlan, Trans. Amer. Philos. Soc., 1830, 3, p. 464.

Type locality: - Marshes and rivulets, Southern United States [Camden, Kershaw Co., S. C.?]. Type, Aead. Nat. Sci. Philad. (1 ơ).

17a. Cambarus blandingil acutus.

Cambarus acutus Girard, Proc. Acad. Nat. Sci. Philad., 1852, 6, p. 91.

Cambarus acutissimus Girard, Proc. Acad. Nat. Sei. Philad., 1852, 6, p. 91. Type locality: - Affluent of Mobile River, Kemper Co., Miss. Type probably destroyed in the Chicago fire in 1871; paratypes (?), Aead. Nat. Sei. Philad. (2).

Type locality: - Affluent of Mobile River, Kemper Co., Miss. Type probably destroyed in the Chicago fire in 1871.

18. Cambarus hayt.

Cambarus hayi Faxon, Proc. Amer. Acad., 1854, 20, p. 108.

Type locality: - Maeon, Noxubee Co., Miss. Type, M. C. Z., No. 3,533; paratypes, U. S. N. M., No. 19,752, 21,850.

19. Cambarus fallax.

Cambarus fallax Hagen, Mem. M. C. Z., 1870, 2, p. 45.

Type locality:-Florida. Cotypes, Boston Soc. Nat. Hist. (1 o f. II., 1 o ); M. C. Z., No. 3526 (1 o7 f. I., 1 శ f. II.).

פ0. Cambarus acherontis.

Cambarus acherontis Lömnberg, Bihang K. Srenska Vet.-Akad. Handl., 1894, 20, af. 4, no. 1, p. 6. 
Type locality: - Subterranean rivulet about 42 feet from surface, Lake Brantley, Orange Co., Fla.

21. Cambarus charkit.

Camburus clarkii Girard, Proe. Acad. Nat. Sci. Philad., 1852, 6, p. 91.

Type locality: - Between San Antonio and El Paso del Norte, Texas. Types probably destroyed in the Chicago fire in $187 \mathrm{I}$.

21a. Ciamalius clarkit paeninsulanus.

Cambarus clarkii paeninsulanus Faxon, supra, p. 369.

Type locality: - Threc miles below Horse Landing, St. John's River, Florida. Type, M. C. Z., No. 3,530 (1 or, f. II.); paratypes, U. S. N. M., No. 28,587, 28,589; M. C. Z., No. 7,370 (Beecher Point, st. John's River, Fla.).

22. Cambarus troglodytes.

Astucus troglodytes LeConte, Proe. Acad. Nat. Sci. Philad., 1S55, 7, p. 400.

Astacus fossarum LeConte, Proc. Acad. Nat. Sci. Philad., 1S55, 7, pl. 401. Type locality: - Ditches, Lower Cieorgia. Cotypes, M. C.Z., No. 3377; Acad. Nat. Sci. Philad.

Type locality: - Rice-fields, Georgia. Cotypes, M. C. Z., No. 3,375 (o', f. I.); Acad. Nat. Sci. Phila. (o f. I.).

23. Camibarus evermanni.

Camburus evermunm Faxon, Proc. U. S. Nat. Mus., May 22, 1890, 12, p. 620.

Type locality: - Escambia River, at Flomaton, Eseambia Co., Ala. Type, M. C. Z., No. 3,834 (1 \% f. I.).

24. Cambarus viae-viridis.

Cambarus viae-viridis Faxon, supra, p. 370.

Type locality: - St. Francis River, Cireenway, Clay Co., Arkansas. Type, M. C. Z., No. 7,336.

25. Cambarus barbatus.

Astueus penicillatus LeConte (nee Olivier, 1791), Proc. Acad. Nat. Sei. Philad., 1855, 7, p. 401. Type locality:-Lower Georgia.

Cambarus bubutus Faxon, Proc. U. ... Nat. Mus., May 22, IS90. 12, p. 621. Type loculity: - Cieorgia. Type, М. (. Z., No. 279 (1 o f. 1.); parutypes, M. C. Z., No. 3,845, Excambia River, Flomaton, llabma. 
26. Cambarus Wiegnanni.

Astacus (Cambarus) wicgmanni Erichson, Mrehiv Naturgesch., 1846, 12 , 1, p. 99.

Type locality: - Mexico. Type apparently lost from the Berlin Mus.

27. Cambarus hinei.

Cambarus (Cambarus) linei Ortmann, Ohio Naturalist, Dee. 1905, 6, p. 401.

Type locality: - Near Cameron, Cameron Co., La.

28. Cambarus allent.

Cambarus alleni Faxon, l'roe. Amer. Aead., 18\$4, 20, p. 110.

Type lorrlity: - St. John's River, Hawkinsville, Orange Co., Fla. Type, M. C. Z., No. 3,591 (1 or f. I.).

29. Cambarus pelletcidus.

Astacus pellucidus Tellkampf, Areh. Anat. Physiol. wiss. Med., 1844, p. 383.

Orconectes incrmis Cope, Aner. Nat., July, 1572, 6, p. 419; 3d and 4th Amn. Rept. Geol. Surv. Indiana, 1872, p. 173. Type locality:- Wyandotte Cave, Indiana.

Typc locality: - Mammoth Cave, Kentueky. Type, Berlin Mus.

29a. Cambarus pellucidus testil.

Cambarus pellueidus, var. testii Hay, Proe. Indiana Iead. Sei., 1891, p. 148; Proc. U. S. Nat. Mus., Sept. 2S, 1893, 16, p. 285.

Type locality: - Mayfield's Cave, Monroe Co., Ind. Types, U. S. N. M., No. 17,702; paratypes, U. S. N. II., No. 19,765, 19,760, 22,431; 1I. C. 7., No. 7,431 .

$\S I V$. Third segment of fourth pair of legs of male hooked. Inner and onter parts of the first pair of abdominal appendages of male closely appressed, outer part terminating in a recurved horny (in form I.) tooth; the inner part giving off a long horny (in form I.) spine at an acute angle with the axis of the limb. (Subgen. Paracambarus of Ortmann.)

30. Cambarus paradoxus.

Cambarus (Paracambarus) paradoxus Ortmann, Proe. Washington Acad. Sci., May 3, 1906, 8, p. 3.

Type locality: - Sierra de Zacapoaxtla, State of Puebla, Mexico ("misseaux torrentueux des montagnes, a le cañada de Tetela de Ocampo"). Types, 
Mus. Hist. Nat. Paris (1 of f. I., 1 o f. II., 1 क) ; paratypes, Carnegie Mus. Pitstsurgh; M. C.Z., No. 6,955 (1 or f. I., 1 ơ f. II., 1 क).

$\$ Y$. Third segment of second and third pairs of legs of male hooked. First pair of abdominal appendages of male not trumeate, inner and outer parts separate and divergent for some distance from the tip; outer branch cleft into two slender teeth at the cnd; inncr branch either acute or spatulate at the tip. (Subg. Cambareluus of Ortmann.)

31. Cambarus shufeldtil.

Cambarus shufeldtii Faxon, Proe. Amel. Acad., 1884, 20, p. 134.

Type loenlity: - Near New Orleans, La. Cotypes, U.S. N. N., No. 4,860; N. C. Z., No. 3,684.

32. Cambarus montezUnaE.

Cambarus montezumac Saussure, Rev. et Mag. Zool., 1857, sér. 2, 9, 1. 102.

Type loculity: - Swanps of the Valley of Mexico; specifically, ponds in the park of Chapulepee, Mexico. Cotypes, Genera Mus.; Berlin Mus.; U.S. N. M., No. 20,683 (ex Genera Mus.).

32a. Cambarus montezumae dugesit.

C'ambarus montezumae dugesii Faxon, Proc. U. S. Nat. Mus., Feb. 17, 1898, 20, p. 660 .

Type locality: - State of Guanajuato, Mexico. Types, U. S. N. M., No. 16,087; paratypes, M. C. Z., No. 4,339.

32h. Cambarus montezumae areolatus.

Cambarus montezumae, var. areolata Faxon, Mem. M. C. Z., 1S85, 10, p. 123.

Type locality:- Near Parras, Cohahuila, Mexico. Type, M. C. Z., No. 3,650 .

32e. Cambarus montezumae chapalanus.

Cambarus chapalanus Faxon, Proc. U. S. Nat. Mus., F'eb. 17, 1S98, 20, p. 661 .

Type locality: - Lake Chapala, State of Jaliseo, Mexico. Type, U. S. N. M., No. 17,698 (1 o $)$; paratypes, U. S. N. M., No. 16,294 (2 o7); M. C. Z., No. $4,777\left(1 \sigma^{7}\right)$.

32d. Cambarts montezumae occidentalis.

Cambarus montezumac oecidentalis Faxon, Proc. U. S. N. M., Feb. 17, 1S9S, 20. p. 661 . 
Type loeality: - Mazatlan, State of Cinaloa, Mexien. Types, M. C. Z., No. 3,652 .

\$ VI. Third segment of third pair of legs of male hooked. First pair of abdominal appendages of male (usually elougate) split into two rami, straight or somewhat recurved, and acute at the tips. (Subg. Faxonius of Ortmann.)

33. Cambarus harrisonit.

Cambarus harrisonii Faxon, Proe. Amer. Acad., 18\$t, 20, p. 130.

Type locality: - Irondale, Washington Co., Mo. Types, M. C. Z., No. 3,586; paratypcs, U. S. N. M., No. $25,826$.

34. Cambarus sloanil.

Cambarus sloanii Bundy, Bull. Illinois State Lab. Nat. Hist., Dee., 1876, 1, p. 24 .

Type locality:- New Albauy, Floyd Co., Ind. Types, M. C. Z., No. 3,806 (1 क्र f. I., 1 क क).

35. Cambarus indanensis.

Cambarus indianensis Hay, 20th Amm. Rept. Depart. Geol. \& Nat. Resourees Indiana, 1896, p. 494.

Type locality: - Patoka River at Patoka, Gibson Co., Ind. Types, U. S. N. M., No. 14,624, 2 ơ f. I., 2 \&; paratypes, M. C. Z., No. 3,859, 2 가 f. I., 2 ㅇ. 36. Cambarus affinis.

?Cambarus limosus Rafinesque, Amer. Monthly Mag. \& Crit. Rev., Nor. 1817, 2, p. 42. Type locality: - In the muddy banks of the Delaware River, near Philadelphia, Pa. (Indeterminable from the description; types not extant.)

Cambarus affinis Say, Journ. Acad. Nat. Sci. Plilad., 1817, 1, p. 168.

Cambarus pcalei Girard, Proc. Acad. Nat. Sei. Philad., 1552, 6, p. 87. Type loeality: - Potomae River at Washington, D. C. Type, U. .. N. N., No. 2,081 (2 or, 2 \&).

Type locality: - Delaware River.

37. Cambarus propinqués.

Cambarus propinquus Girard, Proe. Acad. Nat. Sei. Philad., 1852, 6, p. \&8.

Type locality: - Garrison Creck, Sacket Harbor, Jefferson Co., N. Y., Four-mile Creek, Oswego, Oswego Co., N. Y. Types probably destroyed in the Chicago fire in 1871; paratype (?), Aead. Nat. Sci. Philad. (1 of).

37a. Cambarus propinques sanborni.

Cambarus sanbornii Faxon, Proe. Amer. Acad., 1S\$1, 20, p. 128. 
Type locality: - Oberlin, Lorain Co., Ohio. Types, M. C. Z., No. 3,692; paralypes, M. C. Z., No. 3,5s7 (Smoky Creek, Carter Co., Ky.).

38. Cambarus obscurtis.

Cambarus obscurus Hagen, Men. M. C. Z., 1870, 2, p. 69.

Type locality: - Cienesee River, Rochester, Momroe Co., N. Y. Cotypes, M. C. Z., No. 1\$1, 3,353, 3,35t; U. S. N. M., No. 4,971; Mus. Hist. Nat. Paris; Würzhurg Mus.; Australian Mus., Sydney.

39. Cambalius mrichionianus.

Cambarus crichsoniamus Faxon, Proe. U. S. Nat. Mus., Feb. 17, 1898, 20, p. $(659$.

Type locality: - Rip Roaring Fork, five miles northwest of Cireeneville, Greene Co., Tenn. Cotypes, U.S. N. M., No. 20,7S7; M. C. Z., No. 4,347.

40. Cambarus rusticus.

Cambarus rusticus Cirard, Proc. Acad. Nat. Sci. Philad., 1852, 6, p. SS.

Cumbarus placidus Hagen, Men. M. C. Z., 1570, 2, p. 65. Type locality:Lebanon, Wilson Co., Temn.; Quiney, Adams Co., Ill.; Texas. Cotypes, M. C.Z., No. 289, 290, 170; U. S. N. M., No. 4,966; Mus. Hist. Nat. Paris; Würzburg Mus.; Australian Mus., sydney.

C'ambarus juecnilis IIagen, Mem. M. C. Z., 1870, 2, p. 66. Typc locality:Litte Hickman, Jessamine Co., Ky. Cotypes, M. C. Z., No. 213, 3,347; U. S. N. M., No. 4,967; Mus. Hist. Nat. Paris; Würzburg Mus.; Australian Mus.

Cambarus uisconsincnsis Bundy, Bull. Ill. State Lab. Nat. Hist., Dee., 1576, 1, p. 4. Type locality:-Racine, Racine Co., Wisconsin. Type, M. C. Z., No. 3.448 (1 o f. II).

Type locality: - Ohio River, at Cincimati, Ohio. Types probably destroyed in the (hicago fire in 1871; paratype (?), Acad. Nat. Sci. Philad.

41. Cambarus Forcers.

Camburus forceps Faxon, Proe. Aner. Aead., 1S\$4, 20, p. 133.

Type locality:-Cypress Creek, Lauderdale Co., Ala. Cotypes, U. S. N. M., No. 4,880; M. C. Z., No. 3,582 .

42. Cambarus neglectus.

C'ambarus neglcetus Faxon, Bull. Washburn College Lab. Nat. Hist., Oet. 31, $1885,1, \mathrm{p} .142$.

Type locality: - Nill Creek, Wahaunsee Co., Fansas. Cotypes, M. C. Z., No. 3,757; Mus. Washburn College, Topeka, Kans. 
43. Cambarus spinosus.

Cambarus spinosus Bundy, Proc. Acad. Nat. Sci. Philad., 1S77, p. 173.

Type locality: - Etowah, Oostanaula, and Coosa Rivers, near Rome, Floyd Co., Georgia. Cotypes, M. C. Z., No. 3,540, 3,541 (4 o f. II., 3 \&); U.S. N. M., No. 19,779 (3 o' f. II., 2 우).

43a. Cambarus spinosus gulieluit.

Cambarus spinosus gutielmi Faxon, supra p. 375.

Type locality: - Near Rossville, Walker Co., Georgia. Types, U. S. N. M., No. 26,379 ; paratypes, M. C. Z., No. 7,448 (1 o' f. II., 1 ㅇ ).

44. Cambarus putnami.

Cambarus putnami Faxon, Proc. Amer. Lead., ISS4, 20, p. 131.

Type locality: - Bear Creek, a tributary of Green River, Grayson Springs, Grayson Co., Ky. Types, M. C. Z., No. 3,568; paratypes, M. C. Z., No. 3,569 (Green River, near Mammoth Cave, Ky.), No. 3,570 (Roeky Creek, near Grayson springs, Ky., 1 §); U. S. N. M., No. 10,130 (Crayson springs, Ky.); St. Petersburg Mus. (Green River, Ky., 1 ơ , 2 ).

45. Cambarus hylas.

Cambarus hylas Faxon, Proe. U. S. Nat. Mus., May 22, 1890, 12, p. 632.

Type locality: - West Fork of Black River, Reynolds Co., Mo. Typcs, M. C. Z., No.3,S58; paratypes, U.S. N. M., No. 25,827 (1 o7, 1 q).

46. Cambarus nedius.

Cambarus medius Faxon, Proe. Amer. Acad., 1854, 20, p. 121.

Type locality: - Irondale, Washington Co., Mo. Types, M. C. Z., No. 3,585 ( 1 ○ f. I., I ㅇ).

47. Cambarus compressus.

Cambarus eomprcssus Faxon, Proc. Amer. Acad., 1884, 20, p. 127.

Typc locality: - Seeond Creek, Waterloo, Lauderdale Co., Mla. Cotypes, U. S. N. MI., No. 4,878; M. C. Z., No. 3,583.

4S. Cambarus meekt.

Cambarus mecki Faxon, Proe. U. S. Nat. Mus., Feb. 17, 1898, 20, p. 657.

Type locality: - Walmut Fork of Big Piney Creek, Swain, Newton Co., Ark. Types, M. C. Z., No. 4,363; puratypes, U. S. N. M., No. 19,680; Mus. Zool. Torino. 
49. Cambarus longidigitus.

Cambarus longidigitus Faxon, Proc. U.S. Nat. Mus., Feb. 17, 1S9S, 20, p. 653.

Cambarus whitmani stcele, Univ. Cincinnati Bull., 1902, no. 10, p. 24. Type locality: - James River, $\mathbf{I}$ o.

Type locality: - Oxford Bend, White River, [Izard Co.?], Ark. Types, M. C. Z., No. 4,364; paratypes, U. S. N. M., No. $19,683$.

50. Cambarus virilis.

Cambarus viritis Hagen, Mem. M. C. Z., 1870, 2, p. 63.

Cambarus debritis Bundy, Bull. Illinois Ntate Lab. Nat. Hist., Dee., 1876, 1, p. 24. Type locality: - Baraboo River, Ironton, Sauk Co., Wis. Cotype, M. C. Z., No. 3,449 (1 क् f. II.).

Cambarus emesi Streets, Bull. U. S. Cieol. Surv. Terr., 1S77, 3, p. $\$ 03$. Type locality: - Red River of the North, near Pembina, Pembina Co., N. Dakota. Cotypes, U. s. N. M., No. 3,154; M. C. Z., No. 3,545.

Cambarus viridis Moenkhaus, Proc. Indiana Acad. Sci. for 1902, 1903, p. 111 (per crrorem vice "viritis").

Type locality: - Lake Superior. Types, M. C. Z., No. 1,151; paratypes, M. C. Z., No. 194, 203 (Lake Superior), No. 190 (Quincy, Ill.), No. 3,342 (Lake Winnipeg), No. 3,343 (Red River of the North), No. 3,344 (Saskatehewan River); Mus. Hist. Nat. Paris (Lake Superior); Würzburg Mus. (Lake Superior); Australian Mus., Sydney.

51. Cambarus pilosus.

Cambarus pitosus Hay, Proc. U. S. Nat. Mus, Oct. 11, 1899, 22, p. 121.

Type locality: - Beloit, Mitehell Co., Kansas. Cotypes, U. S. N. M., No. 19,761 (6 ठ f. II.); M. C. Z., No. 7,389 (1 જ f. II.).

52. Canbarus alabanensis.

Cambarus alabamensis Faxon, Proc. Amer. Acad., 1884, 20, 1) 125.

Type loentity: - Second Creek, Waterloo, Iauderdale Co., Ala. Cotypes, U.S. N. M., No. 4,\$76; M. C. Z., No. $3,565$.

53. Cambarus nats.

Cambarus nais Faxon, I3ull. Washbum College Lab. Nat. Hist., I855, 1, p. 140 .

Type loenlity: - Labette Co., Kansas. Cotypes, Mus. Washburn College, Topeka, Kan.; M. C. Z., No. 3,755. 
54. Cambarus muUnis.

Cambarus immmis Hagen, Mem. M. C. Z., 1870, 2, p. 71.

Cambarus sigmifer Herrick, 10th Ann. Rept. Geol. Surv. Minn., 18\$2, p. 253. Type locality: - Grass Lake, Richfield, Hennepin Co., Minn. Cotype, MI. C. Z., No. 3,515, (2 ơ f. I., 1 के).

Type locality: - lawn Ridge, Ill. Types, M. C. Z., No. 18s; paratypes, M. C. Z., No. 3,355 (Belleville, Saint Clair Co., Ill.); Mus. Hist. Nat. Paris (Lawn Ridge, Ill., I ॰

54a. Cambarus imuUnis spinirostris.

Cambarus immunis spimirostris Faxon, Proc. Amer. Acad., 1884, 20, p. 146.

Type locality: - Creek rumning into the east side of Redfoot Lake, near Idlewild Hotel, Obion Co., Tennessee. Cotypes, U. S. N. M., No. 4,655; M. C. Z., No. 3,562 .

55. Cambarus validus.

Cambarus validus Faxon, supra, p. 382.

Type locality: - Huntsville, Madison Co., Ala. Type, M. C. Z., No. 301 (1 ๙ f. I.).

56. Cambarus palmeri.

Cambarus palmeri Faxon, Proc. Acad., 1S\$1, 20, p. 124.

Type loculity: - Creek ruming into the east side of Redfoot Lake, near Irllewild Hotel, Obion Co., Tenn. Cotypes, U. S. N. M., No. 4,872; M. C. Z., No. 3,564 .

56a. Cambarts palmeri longmanus.

Cambarus palmeri longimanus Faxon, Proc. U. S. Nat. Mus., Feb. 17, 1898, 20, p. 655 .

Type locality: - Red River, Arthur City, Lamar C'o., Texas. Types, M. C. Z., No. 7,390; paratypes, M. C. Z., No. 4,361, 4,362, (Goodland, and Kiamichi, Indian Terr. [now Oklahona]); U. S. N. M., No. 19,684 (Arthur, Tex., Indian Terr.); Mus. Zool. Torino.

57. Cambartis diffictlis.

Cambarus difficilis Faxon, Proc. U. S. Nat. Nus., Feb. 17, 1898, 20, p. 656.

Type locality: - Creek tributary to a southern branch of the Canadian River, Mc.lester, Pittsburg Co., Oklahoma. Types, M. C. Z., No. 4,359; paralypes, I. S. N. M., No. 19,687; Mus. Zool. Torino. 
58. Cambarus mississippiensis.

Cambarus mississimpiensis Fixon, Proc. Ancr. Acul., 1851, 20, p. 123.

Type locality: - Macon, Noxubee Co., Miss. Types, Coll. O. P. Hay; paratype, M. C. Z., No. 3,563 (1 우).

59. Cambarus lancifer.

Cambarus lancifor Hagen, Mem. M. C. Z., 1870, 2, p. 59.

Cambarus farmii Meck, Amer. Nat., Dec. 1894, 28, p. 1042. Type locality: St. Francis River at Cireenway and Big Bay, Arkansas. Cotypes, U. S. N. M., No. 19,331; M. C. Z., No. 4,220; MIus. Zool. Tolino.

Type locality: - Root Pond, Miss. Typc, M. C. \%., No. 306 (1 ơ f. I.).

\$VII. Third segment of third pair of legs of male hooked. First pair of abdominal appendages of male short and thick, terminating in two large recurved tooth-like processes, the larger formed by the outer part of the appendage, the smaller by the imner. (Subgen. BARTONius of Ortmann.)

60. Cambarus mamitates.

Oreonectes hamulatus Cope and Packard, Amer. Nat., Nov. 18S1, 15, p. SS1.

Type locality: - Nickajalck Cave, Tennessee. Cotypes, NI. C. Z., No. 3,67s (1 ơ f. II., 1 우).

61. Cambarus setosus.

Cambarus setosus Faxon, Bull. M. C. Z., Dec. 1S89, 17, p. 237.

Type locality: - Wilson's Cive, Jasper Co., Missomi. Types, M. C. Z., No. 4,200; paratypes, M. C. \%., No. 4,201, 4,202; U. S. N. M., No. $25,828$.

62. Cambarus aýmisit.

C'amborus aycrsii Stcele, Univ. C'incimnati Bull., 1902, No. 10, p. 18.

Type locality: - Fisher's Cave, near springfield, Greene Co., Missouri.

63. Cambatus extraneus.

Cambarus extraneus Hagen, Mem. MI. C. \%., 1S70, 2, 1. 73.

Type locality: - Tennessee River, Tenu, near the boundary of Georgia. Types, M. C. Z., No. 175; paralype, U. S. N. N., No. $4,957$.

63a. Cambarus extraneus girdrdinus.

Cambarus girardiame Faxon, Proe. Amer. Acad., 188t, 20, p. 117.

Type lncality: - Cypress Creek, Lauderdale Co., Ala. Cotypes, U. F. N. M., No. 4,882; M. C. Z., No. 3,560. 
64. Cambarus jordani.

Cambarus jordani Faxon, Proe. Amer. Aead., 18st, 20, p. 119.

Type locality: - Etowah River, near Rome, Floyd Co., Georgia. Type, M. C. Z., No. 3,561 (1 क् f. H.).

65. Canbarus cornutus.

Cambarus cormutus Faxon, Proc. Amer. Aead., 1881, 20, p. 120.

Type locality: - Green River near Mammoth Care, Kentucky. Type, M. C. Z., No. 3,560 (I ơ f. I.).

66. Cambarus bartonit.

Astacus bartonii Fabricius, Suppl. Entomol. Syst., 1798, p. 407.

Astacus ciliaris Rafinesque, Amer. Monthly Mag. and Crit. Rev., Nov. 1S17,

2, p. 42. Type locality: - Brooks near Fishkill, Dutchess Co., and Newburgh, Orange Co., New Tork.

Astacus pusillus Rafinesque, Amer. Monthly Mag. and Crit. Rev., Nor. 1S17, 2, p. 42. Type locality:- Brooks near Saratoga springs, Saratoga Co., N. Y.; Lake George, N. I.; Lake Champlain; Utiea, Oneida Co., N. Y.; Oswego, Oswego Co., N. Y.

Type locality:- North America [probably neighborhood of Philadelphia, Pa.]. Type (fragment only), Kỉel MIuseum.

66a. Cambarus bartoni carinirostris.

Cambarus bartonii carinirostris Hay, supra, p. 384.

Type locality: - Gandy Creck, Osceola, Randolph Co., West Virginia. Type, U. S. N. M., No. 23,962; paratypes, M. (.. Z., No. 7,399.

66b. Cambarus bartoni montants.

Cambarus montunus Girard, Proc. Iead. Nat. Sei. Philad., 1852, 6, p. S8.

Type locality: - Within the Nlleghany ranges in Virgina, West Virginia, and Maryland; tributaries of James River, Rockbridge Co., V'a.; Shenandoal River, Clarke Co., Va.; Cumberland, Allegany C'o., Mu.; Sulphur spring, Greenbrier River, W. Va. Types probably destroyed in the Chicago fire in 1871; paratype (?), Acad. Nat. Sei. Philad. (1 ơ juv, Janes River, Va.).

66e. Cambarus bartonil robustus.

Cambarus robustus Girard, Proe. Acad. Nat. Sci. Philad., 18.52, 6, p. 90.

Typc locality:- Humber River, near Toronto, Canada. Type probably destroyed in the Chicago file in 1571; paratype (?), Acad. Nat. Aici. Philad. (1 $\left.\sigma^{7}\right)$. 
66d. Cambarus bartonit longinostris.

Cambarus bartonii, var. longirostris Faxon, Mem. M. C. Z., Oct. 1885, 10, p. 64.

Cambarus bartonii spinirostris Faxon, Proc. U. S. Nat. Mus., May 22, 1890, 12, p. 623 (lapsu calami pro "longirostris").

Type locality: - Near the boundary between western North Carolina and eastern Tennessee. Type, M. C. Z., No. 3,629 (1 ơ f. II.).

66e. Cambartis bartonil longulus.

Cambarus longulus Girard, Proe. Acad. Nat. Sici., Philad., 1852, 6, p. 90.

Type locality: - Unknown; "its range however, is within the Middle States of the Tnion." Type probably destroyed in the chicago fire in 1871.

66f. Cambarus bartonil veteranus.

Cambarus bartonii reteranus Faxon, supra, p. 389.

Type locality: - Indian Creek, Baileysville, Wyoning Co., West Virginia. Type, U. S. N. M., No. 44,712; parutypes, U. S. N. MI., No. 25,020; M. C. Z., No. 7,402 .

66g. Ciambarus bartonil asperimanus.

Cambarus bartonii asperimanus Faxon, supra, p. 391.

Type locality: - Flat Creek, near Nontreat, Buneombe Co., N. C. Typcs, U. S. N. MI., No. 47,375 (2 or f. I.).

66h. Cambarus balitonil acuminatus.

Cambarus acuminatus Faxon, Proe. Amer. Aead., 1S84, 20, p. 113.

Type locality: - Saluda River at Farr's Mills, west of Greenville, Greenville Co., South Carolina. Cotypes, Butler Univ., Irvington, Ind. (1 ơ f. II., 1 q); M. C. \%., No. 3,624 (1 q).

66i. Cambarus bartonit laevis.

Cambarus bartonii laenis l'axom, supra, p. 391.

Type loeality: - Bloomington, MIonroe Co., Indiana. Types, M. C. Z., No. 3,812.

66j. Cambarus bartonil tenebrosts.

C'ambarus bartonii tenebrosus Hay, Proe. U. S. Nat. M[us., S̈ept. 12, 1902, 25, p. 232.

Type locality: - Mammoth Cave, Kentucky. Types, U. ฌ. N. M., No. 22,346 . 
66k. Cambarus bartonil cavatus.

Cambarus bartonii cavatus Hay, Proc. U. S. Nat. Mus., Sept. 23, 1902, 25, p. 435.

Type locality: - Powell River at Tazewell, Claiborne Co., Tennessee. Types, U. S. N. M., No. $25,017$.

67. Cambarus latimanus.

Astacus latimanus LeConte, Proc. Acad. Nat. Sci. Philad., 1S55, 7, p. 402.

Type locality: - Athens, Clarke Co., Georgia. Cotypes, M. C. Z., No. 3,37S (1 or f. I); Acad. Nat. Sci. Plilad. (1 \&); paratypes, M. C. Z., No. 236.

67a. Cambarus latimanus striatus.

Cambarus latimamus striatus Hay, Proc. U. S. Nat. Mus., Sept. 23, 1902, 25, p. 437 .

Type locality: - Nashville, Temn. Type, U.S. N. M., No. 25,019; paratype, M. C. Z., No. 7,348.

6S. Cambarus graysoni.

Cambarus graysoni Faxon, supra, p. 393.

Type locality: - Bear Creek, Grayson Springs, Grayson Co., Kentucky. Types, M. C. Z., No. 3,593.

69. Cambarus ortmanni.

Cambarus ortmanni Williamson, 31st Ann. Rept. Dept. Geol. Indiana, 1907, p. 754 .

Type locality: - Six-MIile Creek and Craven Ditch, tributary to Wabash River, above Bluffton, Wells Co., Indiana. Types, Carnegie Mus., Pittsburgh; paratypes, Coll. IT. P. Hay; M. C. Z., No. 7,587 (1 q).

70. Cambarus carolinus.

Astacus (Cambarus) carolimus Erichson, Arch. Naturgesch., 1846, 12, p. 96. Type locality: - Farm called "Tiger Hall," near Cireenville, Greenville Co., S. C. Type, Berlin Mus. (1 ه) .

70a. Cambarus carolinus dubius.

Cambarus dubius Faxon, Proc. Amer. Acad., 1884, 20, p. 114.

Type locality: - Cranberry Summit [now Terra Alta], Preston Co., West Virginia. Type, M. C. Z., No. 3,631.

70b. Cambarus Carolinus monongalensis.

Cambarus monongalcnsis Ortmann, Annals Carnegie Mus., 1905, 3, p. 395. 
Type loculity: - Head of Cordon's Talley, Edgewood Park, Allegheny Co., Pa. Types, Carnegie MLus.; paralypes, MI. C.Z., No. 6,953: U. S. N. MI., No. 30,613 .

71. Cambarus diogenes.

Camburus diogenes Girutrd, Proc. Aead. Nat. Sci. Philad., 1852, 6, p. 88.

?'umbarns nebraseensis Cirard, Proc. Acad. Nat. Ści. Philad., 1852, 6, p. 91. Type locelity: - Fort Pierere, Nebraska [now in Stanley Co., Sonth Dakota].

Camburus obesus Hagen, Men. M. (․ Z., 1870, 2, 1). S1. Type loealily:Lawn Ridge, Illinois. Types, M. C. Z., No. 195; paratypes, M. C. Z., No. 165 (Bellerille, Saint Clair Co., Ill.), No. 336 (Eranston, Cook Co., Ill.), No. 229 (.rkansas), No. 3,363 (Petersburg, Dinwiddie Co., Va.); Mus. Hist. Nat. Paris (Lawn Ridge, Hll., Belleville, Ill.); St. Petersburg Mns. (Belleville, Ill.).

Type localily: - Near Washington, D. C. Paralype (?), Acad. Nat. Sci. Plilad.

71a. Cambarus dogenes ludovicianus.

Cambarus diogenes, var. Indonicimu Faxon, Proc. Amer. Acad., ISst, 20, p. 144

Type locatily: - New Orleans, La. Cotypes, U. S. N. M., No. 5,625; M. C.Z., No. 3,617.

72. Cambarus argilitcola.

Cambarus argillicola Faxon, Proe. Amer. Acad., 1884, 20, p. 115.

Type localily: - Detroit, Mich. Types, M. G. Z., No. 3,459.

73. Cambarus villeri.

Cambarus uheri Faxon, Proc. Amer. Aead., 1884, 20, p. 116.

Type locality: - Kwamp on Eastern Road near Felsburg, Somerset Co.,

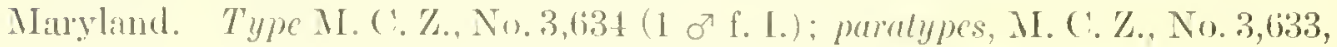
3,635), 3,636 (Dorchestere, Sumerset, and Woreester Cos., Mfd.).

74. CaMbarus ClYPEATUS.

C'amburus clypeculus Hay, Proc. U. S. Nat. Nus. Oct. 11, 1899, 22, p. 122.

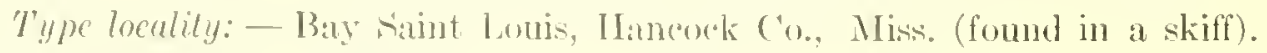
Type, U.s. ‥ M., No. 22,7万s ( 9 ). 
DoubtFul SPECIES, NOT 1NCLUded IN THE PRECEDING LIST.

1. Cambarus ianiculatus.

Astacus maniculatus LeConte, Proe. Aead. Nat. Sei. Philad., 185., 7, p. 401.

Type locality: - In ditehes, Lower Cieorgia.

2. Cambarus stygius.

Cambarus stygius Bundy, Bull. Illinois State Lab. Nat. Hist., 1876, 1, p. 3.

Type locality: - Lake Miehigan at Raeine, Racine Co., Wisconsin (washed up during a violent storm).

3. Cambarus typhlobius.

Cambarus typhlobius Joseph, 57th Jahresber. Sehlesischen Gesellsch. vaterl. Cult., 1879, 1850, p. 202.

Cambarus coccus Joseph, Berl. Entomol. Zeitschr., Dee. 1881, 25, p. 237.

Cambarus stygius Joseph, Berl. Entonol. Zeitschr., April, 1882, 26, p. 12 (nec Bundy, 1876).

Type locality: - Recca River, Grotto of St. Kanzian at Metaùn, near Divazza, Carniola (doubtless an error). 



\section{EXPLANATION OF PLATES.}

Note.- Plates 1-3 are after colour-drawings of living specimens, hy E. N. Fischer. Plates 4-8 are from India-ink drawings by E. N. Fiseher. Plates 9-13 are from plotographs by George Nelson. 

PLATE 1. 
PLATE 1.

Fig. 1.- Cumbarus hageniamus Fuxon. 9. Muldon, Miss. M. C. Z., No. 7.425. $\times 1$. Fig. 2.- Cambarus hageniunus Faxon. 3. Muldon, Miss. M. C. Z., No. 7, 125. X 1 . 

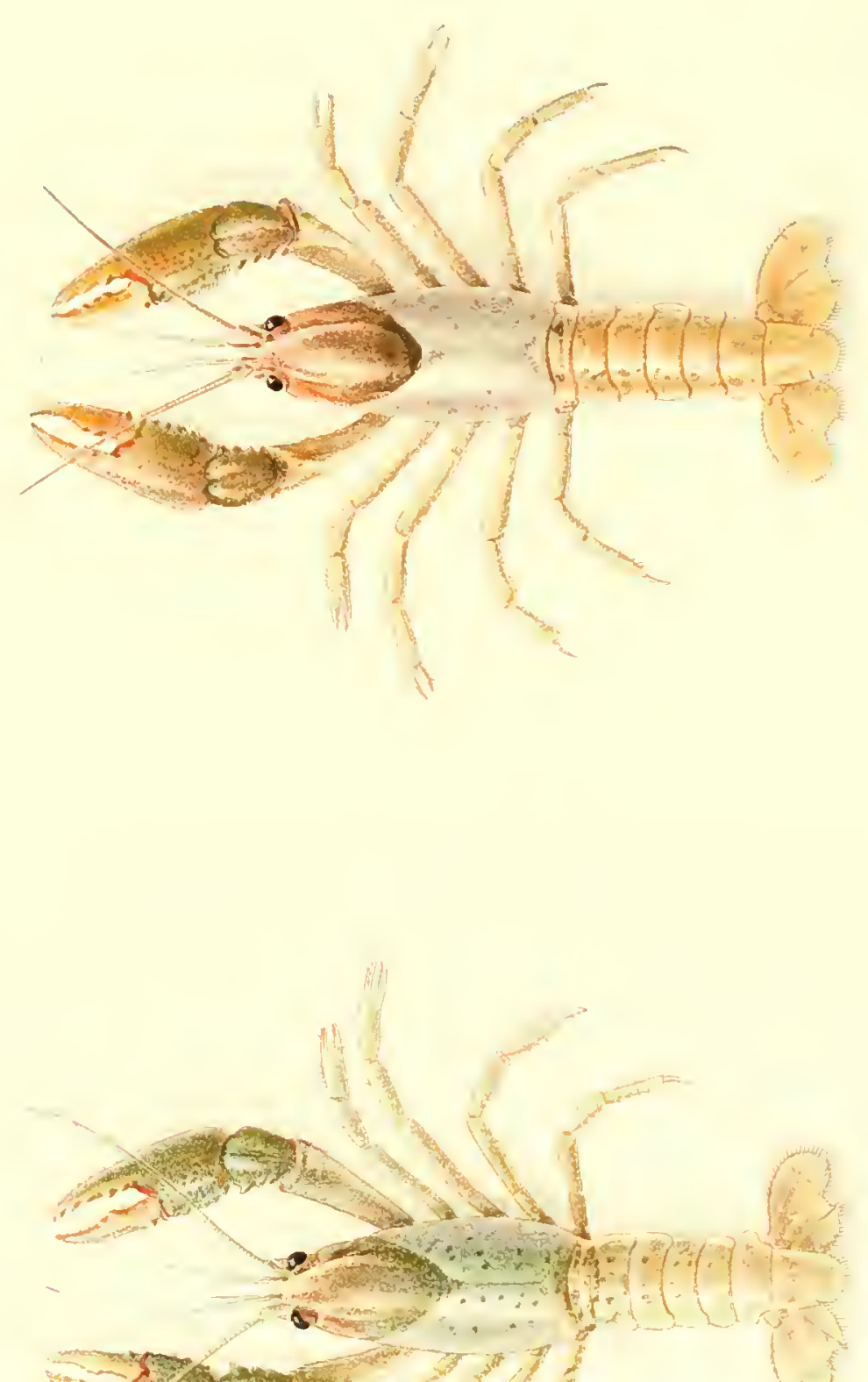

I'LATE 2. 
PLATE 2.

Fig. 1.- Cambames immunis spinimestris Faxon. Junng o. Pontoosue Lake, Lanesboro, Mass, Aug. 12, 1911. M. C.Z., No. 7,364. $\times 3$.

Fig. 2.-Cambarus immunis spinirostris Faxon. 8, form I. Pontoosue Lake, Lanestoro, Mass., Aug. 12, 1911. M1. C. Z., No. 7,36i3. X1. 

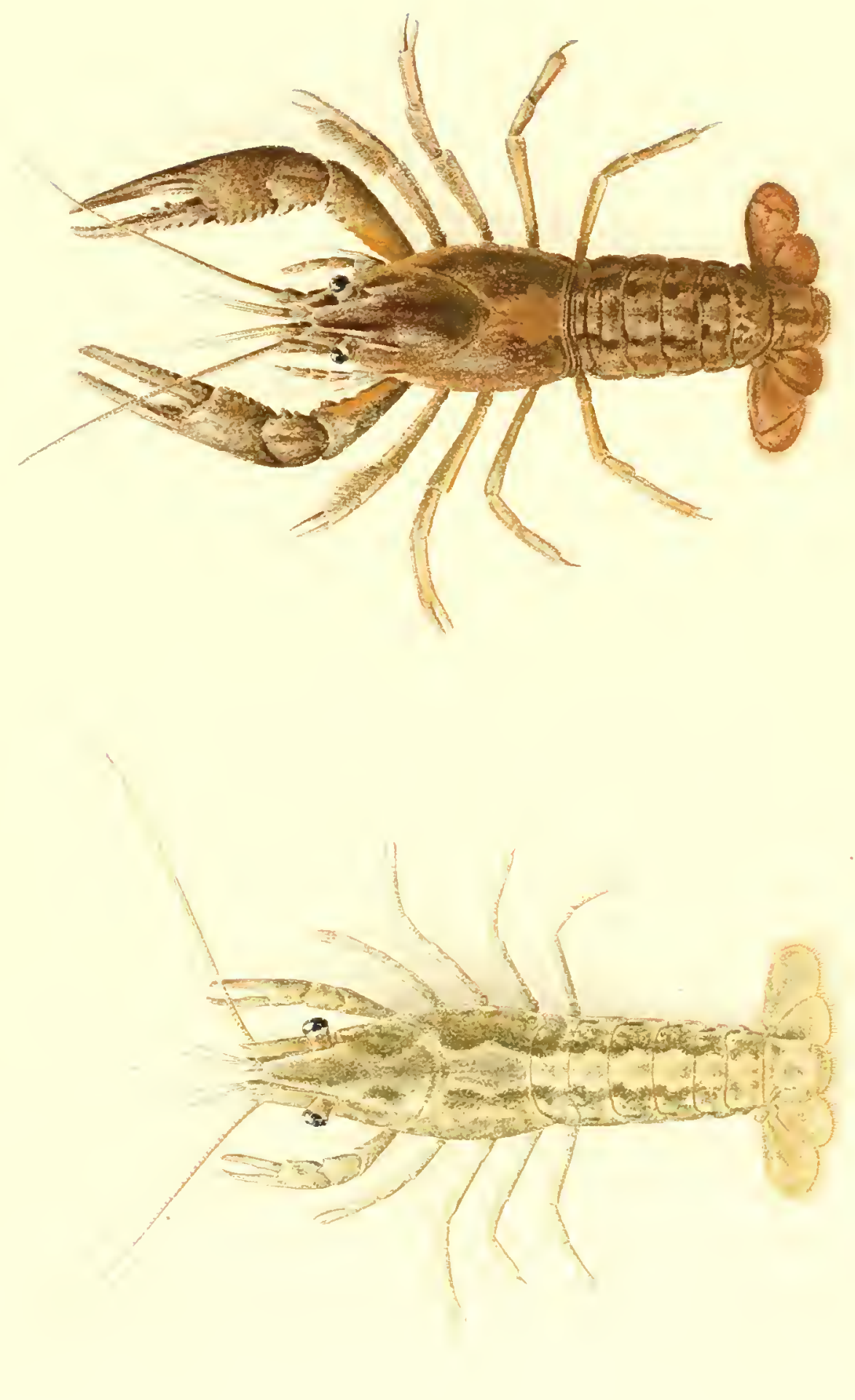

PLATE 3. 


\section{PLATE 3.}

Cambarus bartonii robustus (Girard). Bog River, St. Lamrence Co., N. Y., July, 1912. M. C. Z.. No. $7,440 . \times 1 \frac{1}{2}$. 


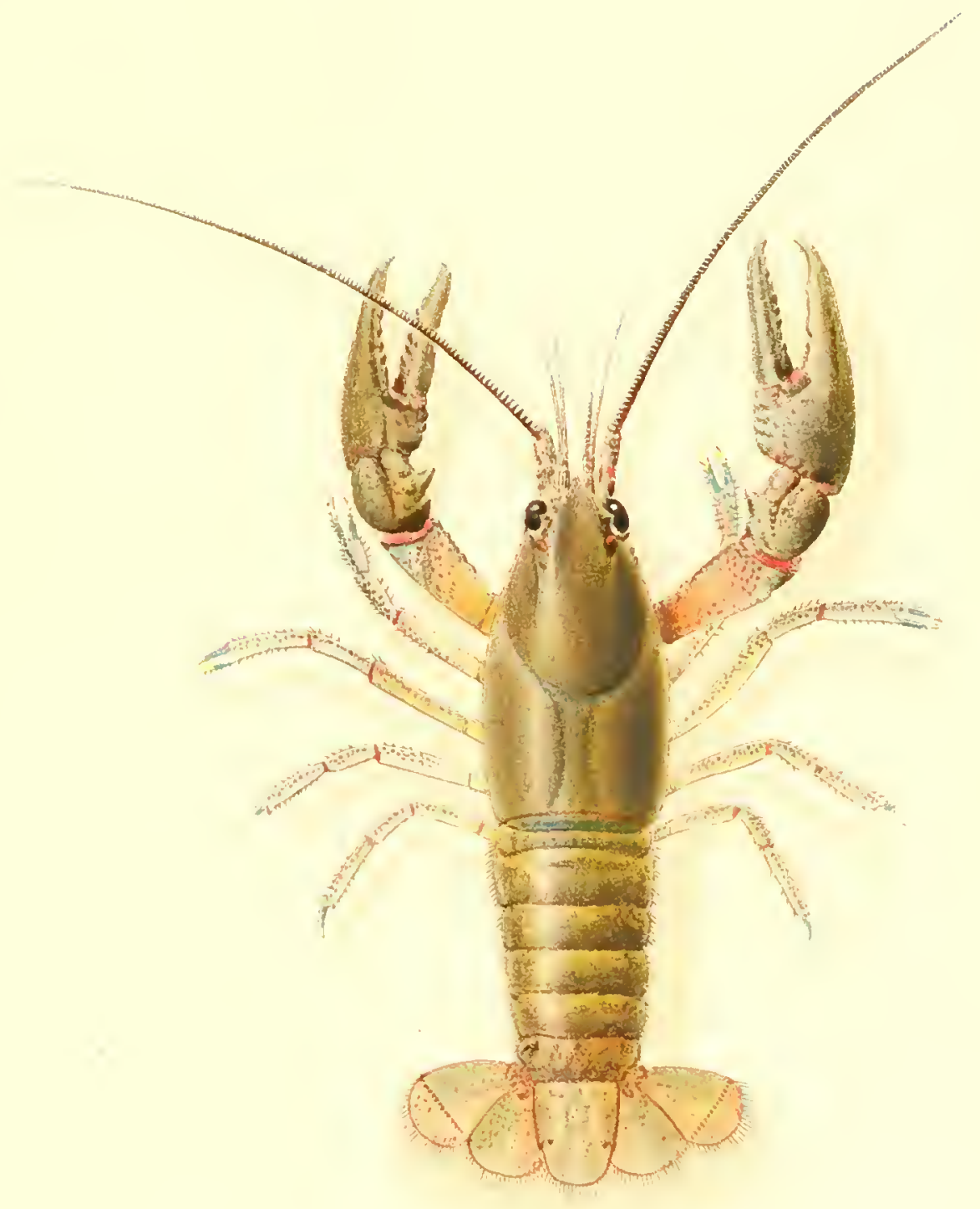



PLATE 4. 
ILATE 4.

Fig. 1.- P'arastacus mancunius Faxon. 6. Corral, Chile, Dec. 18, 190s. Type. M. C. Z., No. 7,355.

Fig. 2.- Epistoma of the same.

Fig. 3.- Antennal seale from the right antenna, upper face. 


$$
\text { 埩 }
$$



Plate 5 
PLATE 5

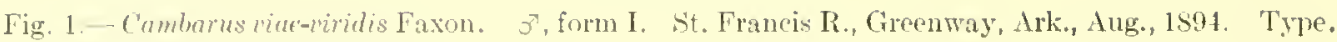
II. C. Z, No. 7,336.

Figr. 2.- Epistoma of the same.

Fig. 3.- Intennal seale of the same.

Fig. 4-Cronopod of the same, inner sids.

Fig. tu. - Cronopod of the sume, outer sill.

Fig. 5.- Right cheliperd of the same.

Fig. 6.- Aunulus ventralis of the female Cumbarus vine-viridis. 
Mem. Mas. Comp. Zoül.

Crayfishes, Plate a
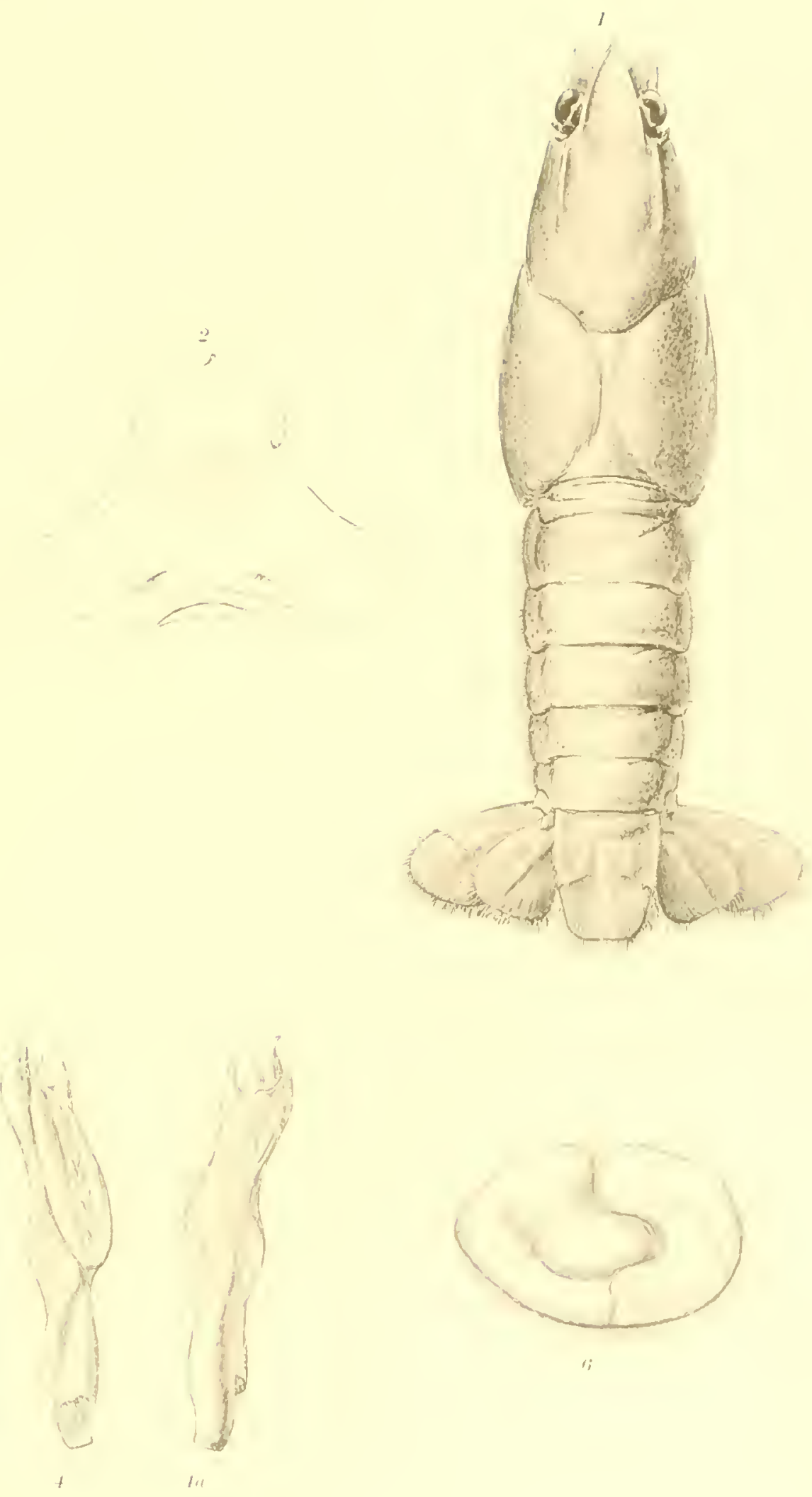




\section{PLATE 6.}

Fig. 1.- Camburus mmmis spimirostris Faxon. Pontoosue Lake, Lanesboro, Mast, 1ug. 12, 1911. M. C. Z., No. 7,363. Gonopod of the 0 , form 1. 1a, outside, $1 b$, front, $1 c$, insirle.

Fig. 2.-Gonopor of the 8 , form II, of the same, $2 a$, out sille, $2 b$, front, $2 c$, insile.

Fig. 3.- Epistoma of the same.

Fig. 4. - Antennal scale of the same.

Fig. 5. - Anmulus ventralis of the of of the same.

Fig. 6.- Chela of the $0^{7}$, form I. of the same. 


$$
\begin{array}{lll}
B 14 & 71 \\
- & 0
\end{array}
$$



PLATE 7. 
PLATE 7.

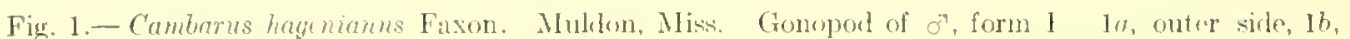
inner side, $1 c$, front.

Fig. 2.-Camburas pllucilles (Tellkampi). Manmoth Cave, Ky. Conopol of or, form I. 2a, outer sicle, $2 h$, inmer sille, 2e, front.

Fig. 3.- C'amburus validus Faxon. Huntsville, Ala. Type. M. C. Z., No.301. Gonopod (o form 1.). $3 a$, outer side, $3 b$, imner side, $3 c$, front.

Fig. 4.- Comburus maluens Faxon. Typu. Antemal soule.

Fig. 5.-Astucers nigreseens fortis Faxon. or. Fall R., Fall City Mills, Cal. Type. IT. B. N. M Antemal seale.

Fig. (i.- Astacus qumblicomeders Faxon, or. Snake R., Upper saluon Falls, Jutho. Type. U.S N. M., No. 23,096. Antennal scale.

Fig. 7.- Cambarus hageniames Faxm. of. Muldon, Miss. Annulus ventralis.

Fig. 8.- Cambarus walihus Faxon. or. Type. Epistoma.

Fig. 3.- Astacers nigrescens fortis Faxun. on. Type. Epistoma.

Fig. 10.- Astrens gambeliz connectons Faxon. of. Type. Epistoma 
Mem. Mus. Comp. Zoöl.

Cratishen, Plate -

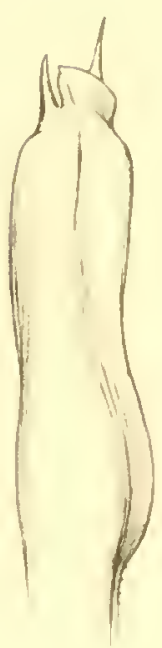

l"

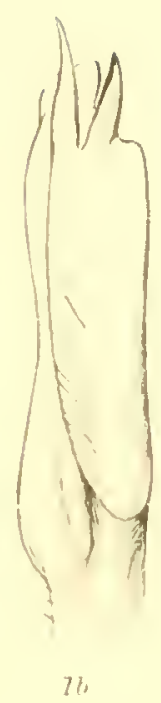

71

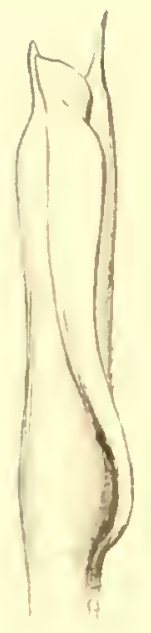

Ir

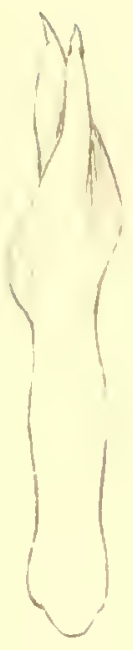

$\stackrel{2}{\prime \prime \prime}$

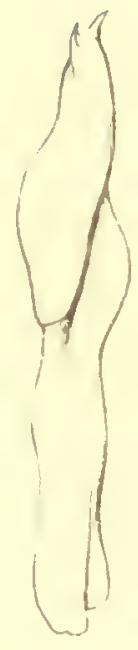

23
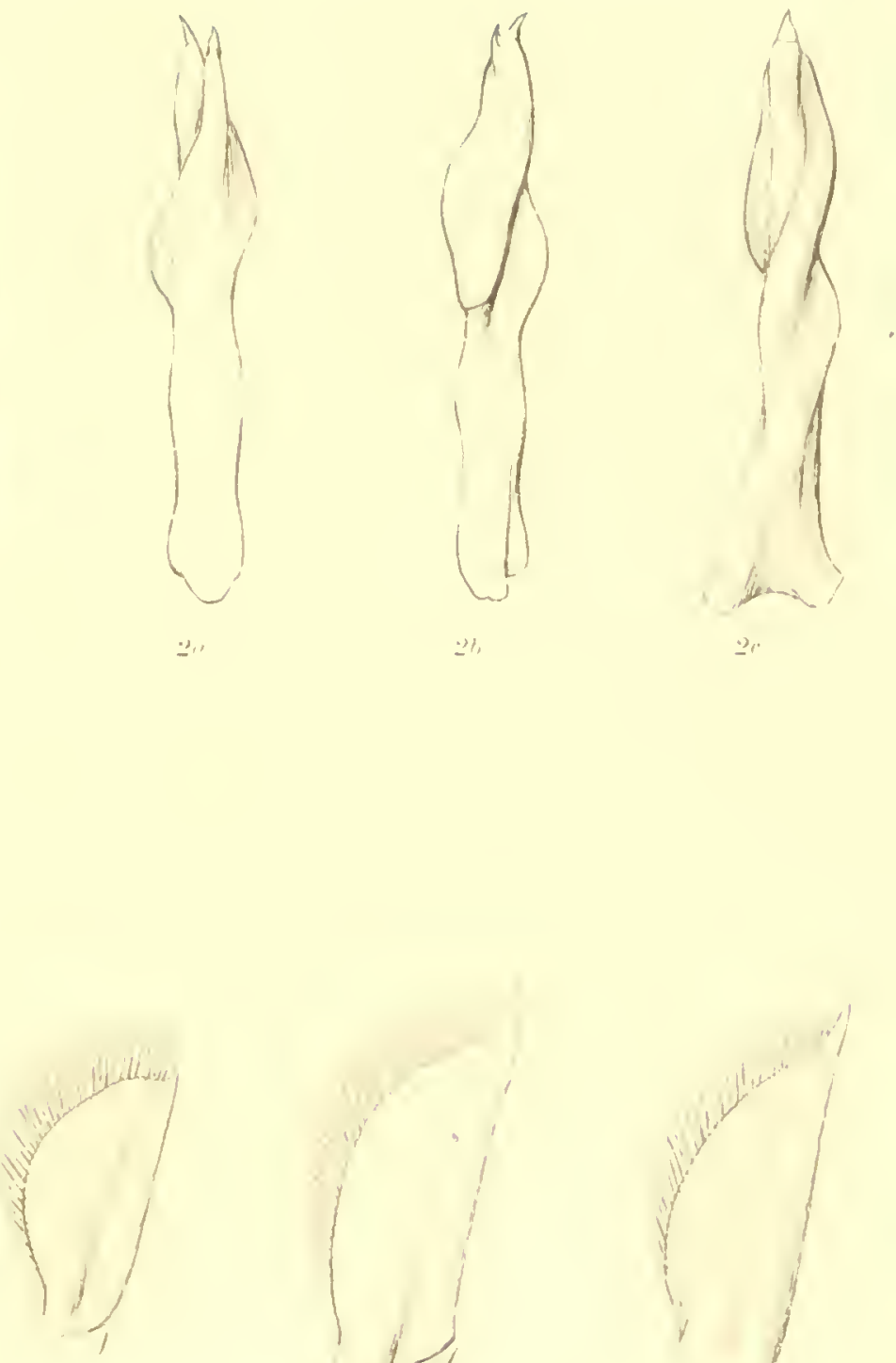

t
4

3

i)

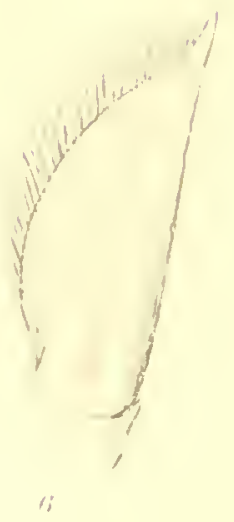

ii

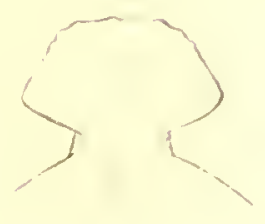

is

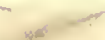

$t^{\prime}$ 

PLATE 8. 
IIATE 8.

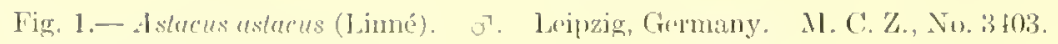

Fig. la.- Cronopod of the sane.

Fig. 1h.- Cheda of the sime.

Fig. le-Antennal srale of the same.

Fig. 1, - Anterior process of the enjictoma of the same.

Fig. le- - Profilo of anterior end of rostrum of the sime.

Fig. 1f.- Plenera of the second and thim aludominal segments of the same.

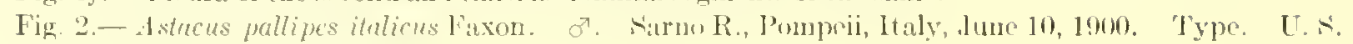
N. M., No. 2S,638.

Fig. 2 at - Crmoport of the same.

Fig. 2h.- Chath of the same.

Fig. 2c.-Antenual scaln of the some.

Fig. 2t.- Anterior process of the epistona of the same.

Fig. 2e:- P'rofile of anterior (nd of rostrum of the sane.

Fig. 2f.- Plemra of the suroud and third abdominal segments of the same.

Fig. 3.- Astacus wallipes Lereboullet. o7. Saone R., Lyons, France. 11. C. Z., No. 3,372.

Fig. 3rt-Cronopol of tly same.

Fig. 3b.- Chela of the sume.

Fig. 3c.- Antemial seale of the same.

Fig. 3it.- Antrrion process of the epistoma of the same.

Fig. 3e- l'rofile of anterior end of rostrum of the same.

Fig. 3f.- Pleura of the second and third aludeminal segments of the same. 

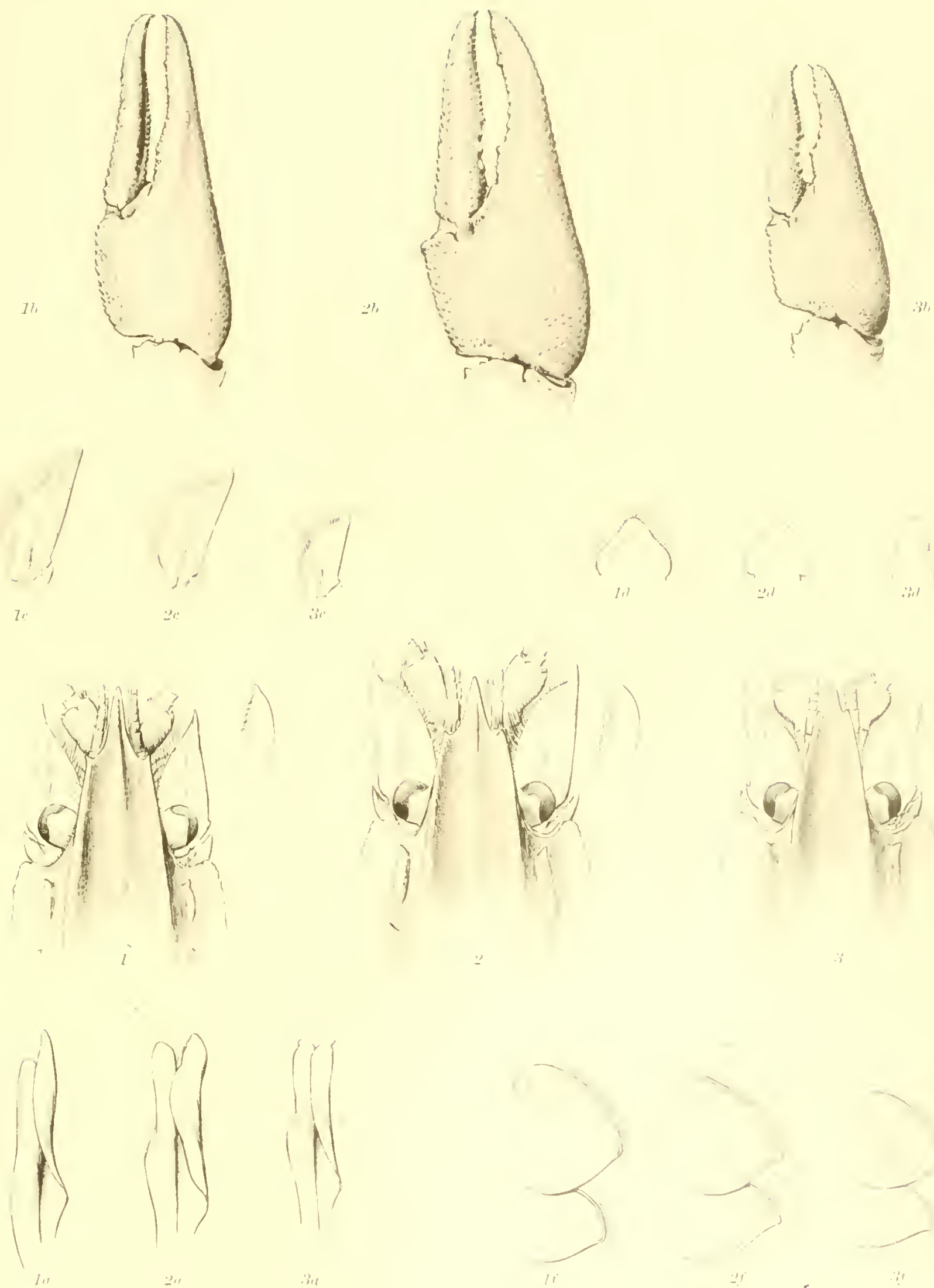

PLATE 9 


\section{PLATE 9}

Fig. 1.- Parastucus spnifrons (Philippi)? Mus, dHist. Nat., Paris. $\times 1$.

Fig. 2.- Astacus nigrescens fortis Faxon. o7. Type. Fall R., Fall City Mills, Cal., Aug. 29, 1898. U. S. N. M. slightly enlarged. 

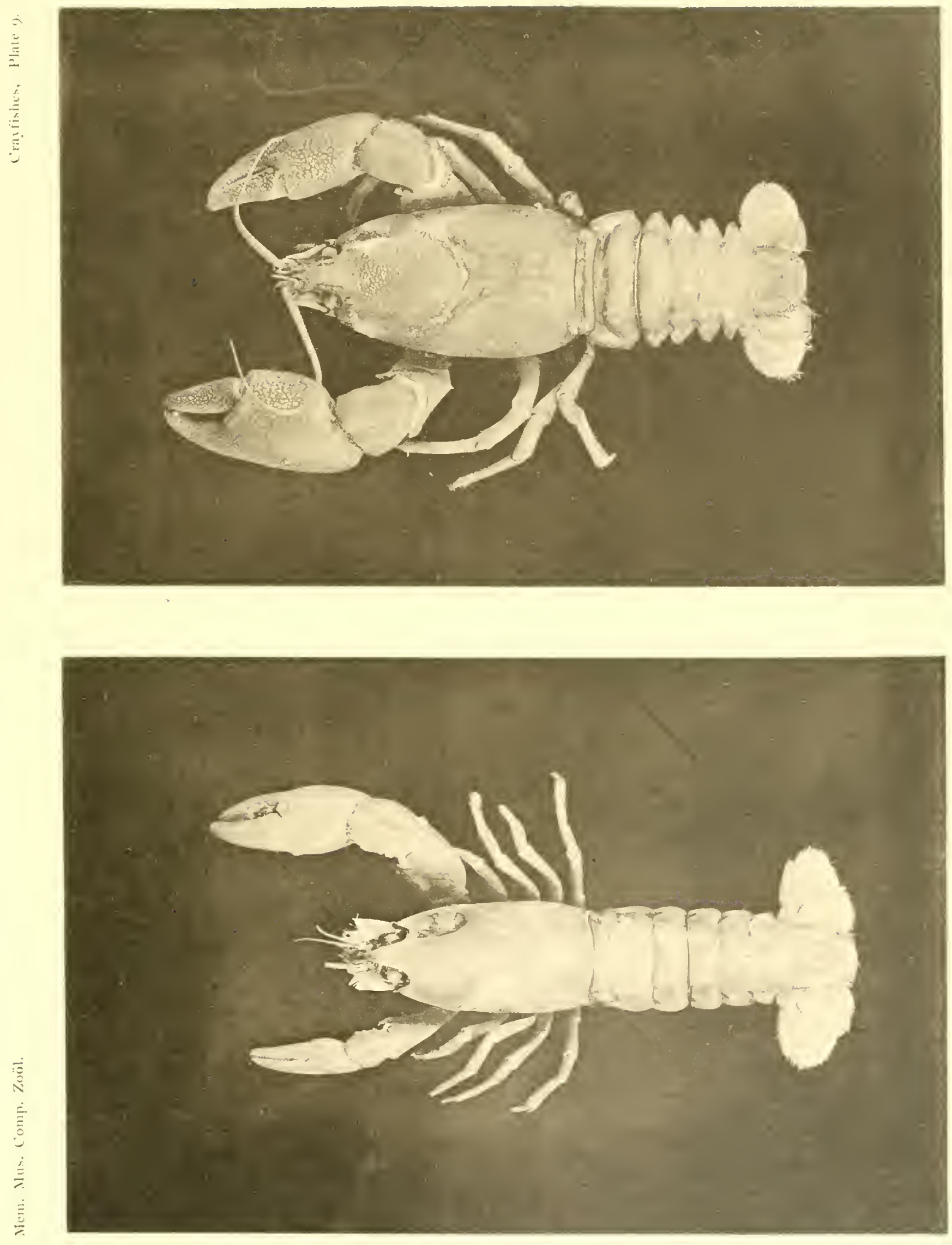

PLATE 10. 
PLATE 10

Fig. 1.- Astucus gambelii connectens Faxon. J. Type. Snake R., Upper Salmon Falls, Idaho, Oct. 3, 1804. U.S. N. M., No. 23,096. Enlargeil.

Fig. 2.- Istacus gambelii with most of the characters of Al. g. comectens. or. Mouth of St. Joe R., Coeur d'Alene Lake, Idaho, IT.S. N. M. $\times 1$. 

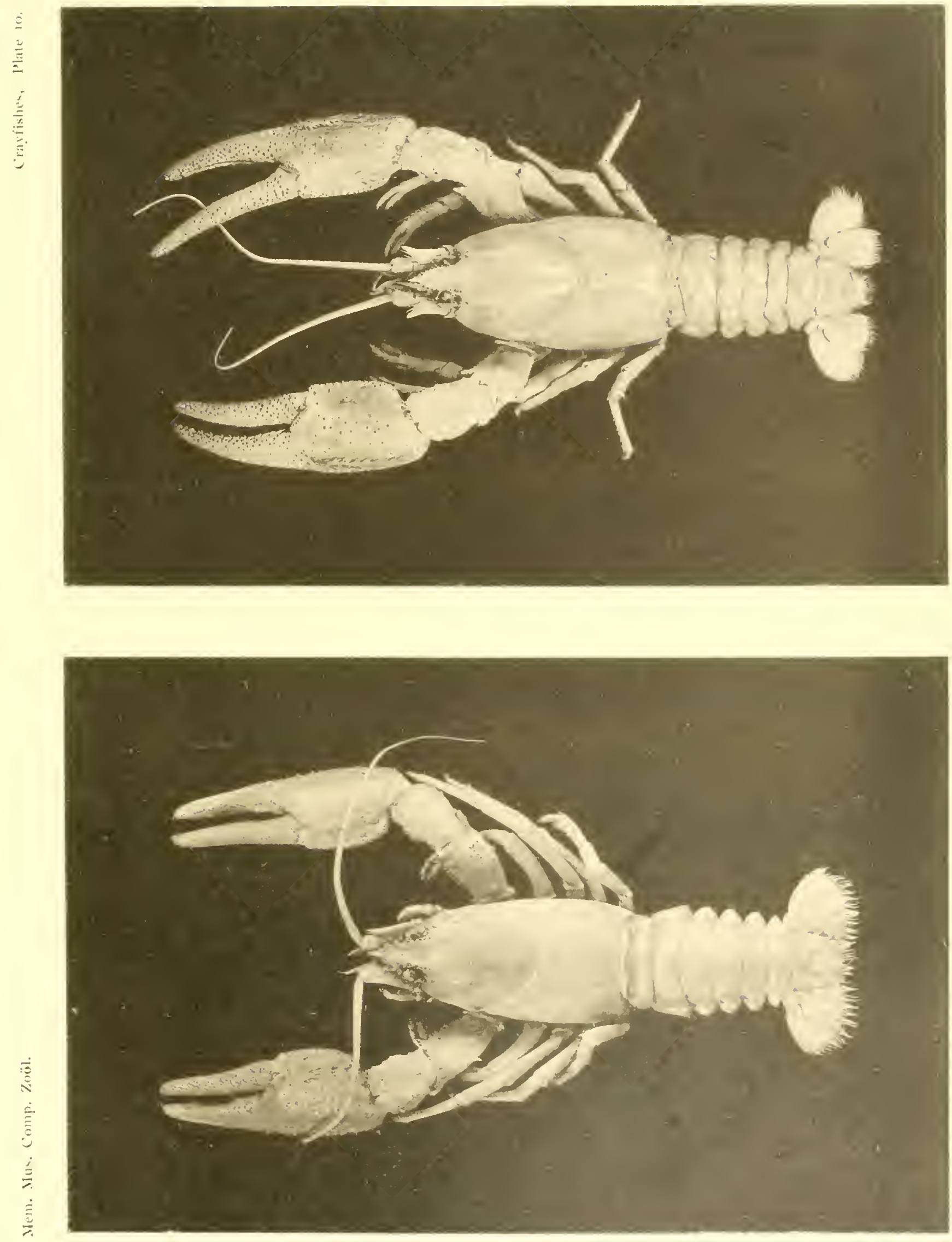

PLATE 11. 
PLATE 11.

Fig. 1.- Astacus klamathensis Stimpson. O?. Portland, Or. U.S. N. M., slightly enlarged. Showing the chelipeds of normal shape.

Fig. 2.- Astacus klamathensis Stimpson. o7. Portland, Or. U.S. N. M., slightly reduced. Showing the abnotmal, atavistic form of the regenerated flaw of the left side. 

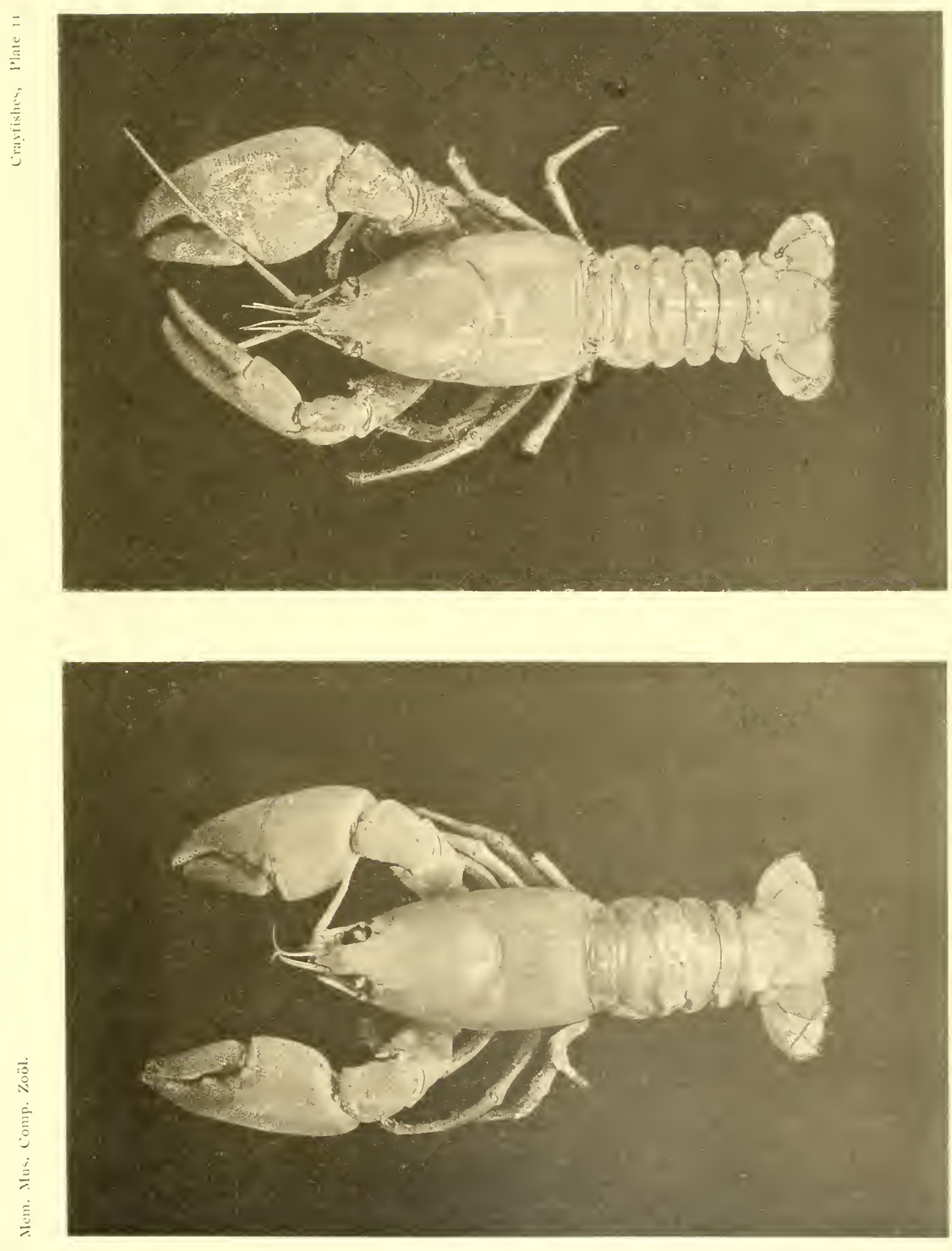

PLATE 12. 
Fig.-A stacus klamathensis Stimuson. or. Portlint, Or. U, S. X. M. X 1. Both of the chelipeds are secontl growths, the left the older.

Fig. 2.- Astacus klamathensis Stimpson. o?. Portland, Or. T. A. N. M. Flightly reduced. Showing both elaws regenerated, of full size, and nearly symmetrieal; yet very different in shape from the normal claw as seen in Plate 11, Fig. 1. 

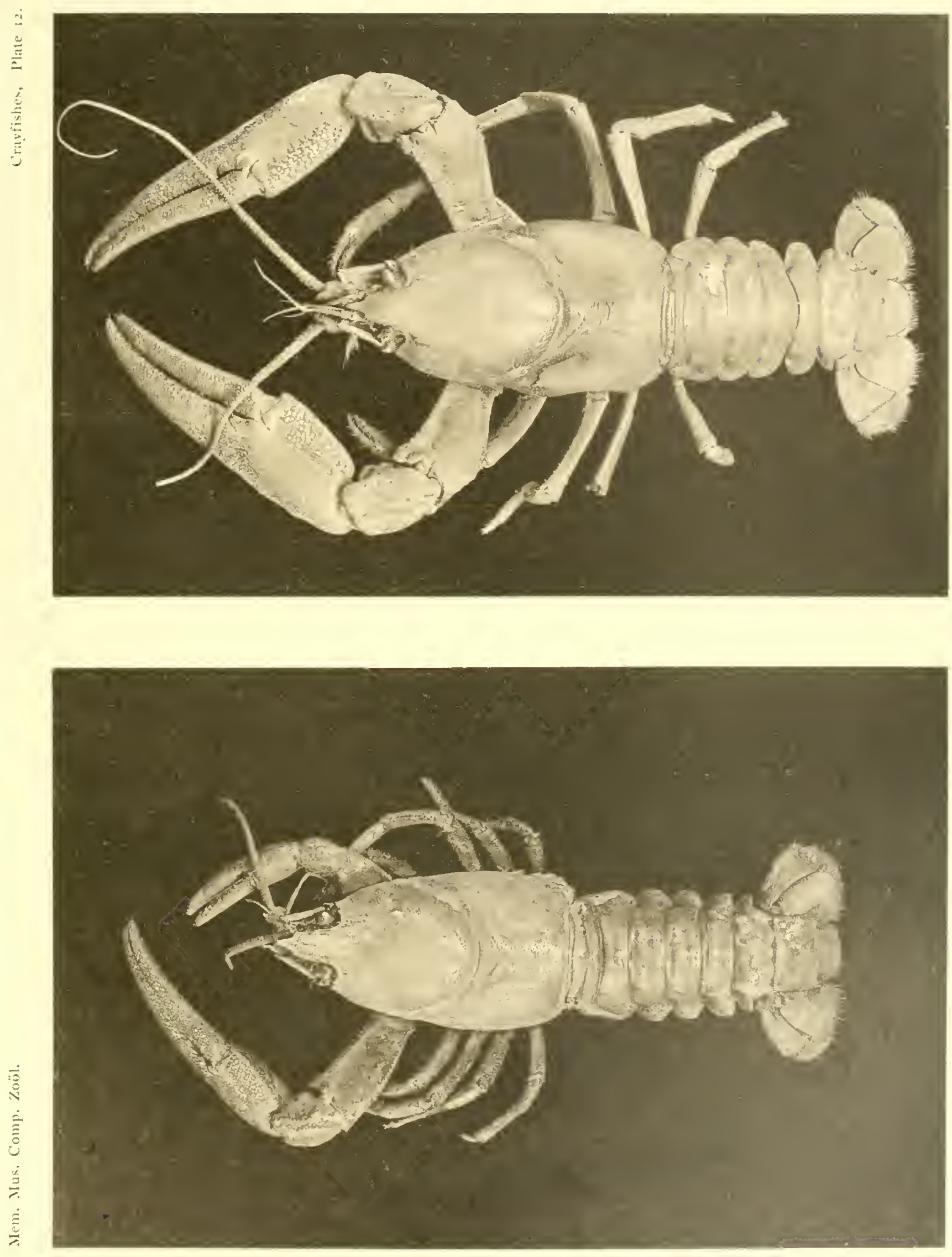

PLATE 13. 
PLATE 13.

Fig. 1.-Cambarus validus Faxon. o7, form I. Type. Huntsville, Ala. M. C. Z., No. 301. X $1 \frac{1}{2}$.

Fig. 2-Camburus bartonii veteramus Fuxon. of, form I. Type. Indian Creek, Baileysville, W. Va. Aug. 16, 1900. U. S. N. M., No. 25,020. Rerlueml. 

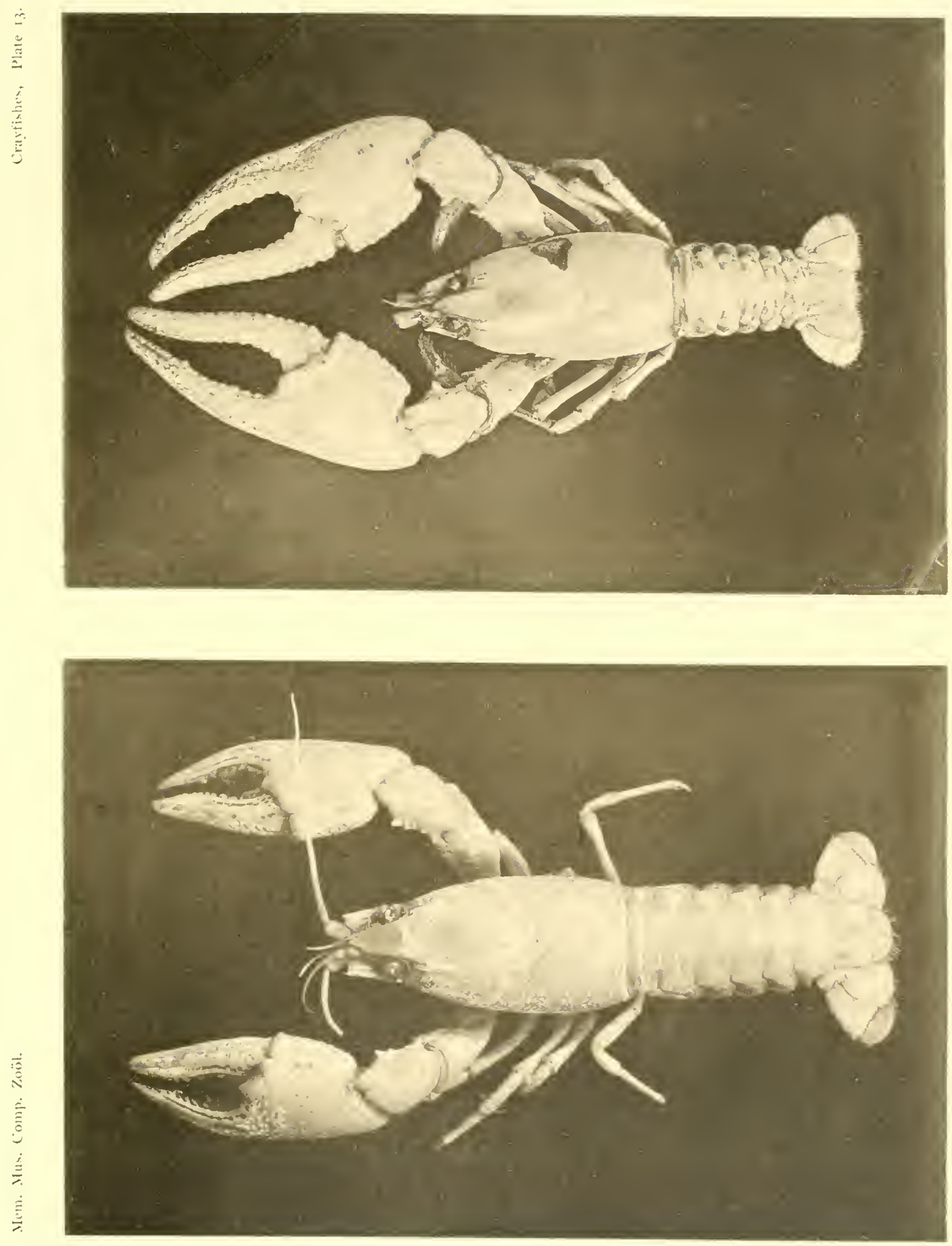





\section{PUBLICATIONS}

OF THE

\section{MUSEUM OF COMPARATIVE ZOÖLOGY AT HARVARD COLIEGE.}

There have heen published of the Bolletin Vols. I. in I.IV.; of the Menorks, Vols. I. to XXIV., and also Vols. XXY. to X.XIX., XYXI, to XXYIY., XXYYi, to XXXYIII, XLI., and XLIV.

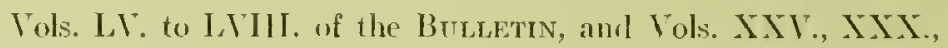
XXXY., XXXIX., XL., XLII., XLIII., XLV. to XLVIII, of the Menorrs, are now in course of publication.

1 price list of the publications of the Muscum will be sent on application to the Director of the Muscum of Comparative Zoölogy, Cambridge, Mass. 